NATURALEZA JURÍDICA DEL CONTRATO DE LEASING EN EL

DERECHO COLOMBIANO

ÓSCAR GARCÍA VEGA 


\title{
NATURALEZA JURÍDICA DEL CONTRATO DE LEASING EN EL DERECHO COLOMBIANO \\ CAPÍTULO I
}

\author{
ASPECTOS FUNDAMENTALES DEL CONTRATO DE LEASING
}

OSCAR GARCIA VEGA

\section{RESUMEN}

El leasing es un instrumento jurídico-financiero que se remonta a la antigüedad ${ }^{1}$, puesto al servicio de los comerciantes y de los empresarios, cuya finalidad

\footnotetext{
1“El leasing es una de las más elocuentes manifestaciones del cambio que se ha venido operando en las costumbres del sector empresarial, particularmente con relación a la manera de decidir sus inversiones en bienes de capital; por lo que, con cierta frecuencia, se le presente ante y sobre todo como una nueva modalidad contractual o técnica de financiamiento de la empresa. A pesar de ello, un sector doctrinario ha cuestionado la novedad del concepto del leasing, considerando que la novedad radica simplemente en el perfeccionamiento y sofisticación que han acompañado al contrato.
}

"Entre los especialistas que han tratado la parte histórica del leasing hay consenso en cuanto que este contrato tiene sus antecedentes en la antigüedad; pero, tal consenso desaparece cuando se trata de precisar el lugar y la época de su origen, dando lugar a la aparición de diversas tesis. Algunos autores creen encontrar el origen entre los sumerios hace 5.000 a.C., en tanto que otros en el Código de Hammurabi o entre los egipcios.

"Las primeras operaciones de leasing, en los tiempos modernos, fueron llevadas a cabo por las empresas explotadoras de los grandes ferrocarriles americanos. Éstas, ante la carencia de capitales para la adquisición de locomotoras, vagones u otros equipos, echaron mano al leasing como última alternativa, lo que les permitió la construcción de casi toda la red ferroviaria de los Estados Unidos, en tiempos de ROCKEFELLER, MORGAN y MELCON. La empresa americana de telecomunicaciones Bell TelephonSystem, en épocas más recientes, decidió operar con éxito bajo este sistema, es decir, arrendando sus teléfonos en lugar de venderlos. El ejemplo fue seguido, años después, por otras grandes empresas, a saber, la International Business Machines, la International CygarMachinery y la UnitedSchoeMachineryCorporation.

"La primera aplicación del lease con fines financieros, recuerda GIOVANOLI, recién se llevó a cabo en 1936, fecha en la que la cadena de supermercados de California celebró un contrato de sale and lease back con una empresa bancaria. Por entonces, igualmente, en Ohio una empresa almacenera vendió el inmueble en el cual operaba a una empresa bancaria, que intervino a título de trustee, es decir, por cuenta de unos inversionistas privados. A continuación, el trustee entregó el inmueble en lease a la empresa usuaria, que fue la vendedora, por un plazo de 99 años acompañada de una opción de compra. Esta técnica, inspirada en los procedimientos de financiación de bienes ferroviarios, practicada desde 1880 con el nombre de "Equipment trust 
económica es poner a disposición de éstos unos bienes y/o innovaciones tecnológicas para el funcionamiento y mejoramiento de la empresa y la actividad económica. Por ello, resulta de capital interés el estudio y análisis respecto de la naturaleza jurídica del contrato $^{2}$ de leasing en el ordenamiento jurídico colombiano; si bien es cierto que la figura es universal, es decir, sobre la que existe un importante desarrollo en el derecho mercantil internacional y en el derecho contractual privado comparado e internacional, existen ciertas particularidades o especificidades en el derecho interno colombiano que vale la pena examinar a la luz de la ley, doctrina y la jurisprudencia local. Aunque en este tipo contractual, así como en todos los demás, no es posible apartarse y hacer tabla rasa de los desarrollos conceptuales y doctrinales sobre el contrato de leasing y su naturaleza jurídica, es factible analizar las particularidades del derecho interno colombiano; en otras palabras, hacer una especie de glocalización jurídica (ULRICH BECK, 1998); es decir, que sin tomar distancia de los conceptos y criterios jurídicos universales (Convenio de Ottawa, leyes modelo, tratados internacionales), se trasplantes y apliquen criterios jurídicos ajustados, acordes a

agreements" o "Philadelphia plan", alcanzó pronto gran auge en el Estado de Ohio como consecuencia de las elevadas tasas de impuestos para la constitución de hipotecas.

"En nuestra opinión, el punto de partida del leasing, tal como se estudia y practica en la actualidad, es decir, como un contrato de financiamiento en el que participan tres sujetos, habitualmente empresas, es el año de 1952, fecha en la que DYAS POWER BOOTHE Jr., luego de advertir el prometedor futuro de esta figura contractual, fundó en San Francisco la UnitedStates Leasing Corporation con un capital de US\$20.0009" (LEYVA SAAVEDRA, 2003, pp. 745-747).

${ }^{2}$ El estudio de la naturaleza jurídica de un contrato se refiere a los elementos, características y función económica y social del contrato; en tratándose del contrato de leasing, resulta de vital interés el análisis sobre la naturaleza jurídica de éste; es decir, de sus elementos, características, función y desarrollo en el ámbito jurídico y empresarial, pues existen criterios divergentes a nivel doctrinal y legal sobre los elementos, características y operatividad de la figura en Colombia; de ahí que en el contexto jurídico nacional esta discusión es de suma importancia a fin de armonizar y unificar los criterios jurídicos que existen en nuestro medio al respecto. La presente investigación se centra precisamente en los elementos, características y función económica del leasing, esto es, a lo que se denomina la naturaleza jurídica del contrato de leasing dentro del escenario doctrinal, legal y jurisprudencial. 
las necesidades y a la realidad jurídica colombiana (Cfr. BONILLA MALDONADO, 2009; igualmente, HAROLD J. BERMAN, 1996).

Esta es la pretensión central, fundamental de esta investigación, esto es, cuál es la naturaleza jurídica del contrato de leasing, cómo se ha desarrollado en Colombia. A partir de este análisis se encuentra que el contrato de leasing es un negocio jurídico de adhesión y, desde esta óptica, se aborda el estudio de la posición de dominio en el contrato de leasing por parte de la compañía de leasing. Estos conceptos resultan esenciales, vitales si se quiere, para la comprensión de la naturaleza jurídica del contrato de leasing. Para este propósito he preferido comenzar por el concepto de leasing, primer elemento de la naturaleza jurídica y de la estructura jurídico-funcional del leasing; luego, me adentro en las características y elementos del contrato de leasing, del tránsito de la función económica a la función social de la figura en el marco de un capitalismo global más humanizado o con rostro humano como lo denominó STIGLITZ (2007, pp. 429 y ss), de la necesidad de introducir en el derecho colombiano la lesión como vicio del consentimiento para equilibrar la relación contractual, del hecho de que el contrato de leasing es un negocio jurídico de adhesión y no de libre discusión, es decir, consensual, así como de las responsabilidades jurídicas que se generan para las partes por objeto y causa ilícitas. Estos aspectos resultan medulares en el análisis sobre la figura jurídica del leasing, y por intermedio de su examen se pretende presentar una visión diferente, crítica y propositiva sobre esta modalidad contractual, que a juicio de muchos está decantada y no requiere más análisis; sin embargo, aquí se desmitifica esta teoría o tesis doctrinal ampliamente aceptada en nuestro medio.

\section{PALABRAS CLAVE}

Contrato de leasing, naturaleza jurídica del leasing, características y elementos del contrato de leasing, negocio atípico, contrato de adhesión. 


\section{ABSTRACT}

The lease is a legal and financial instrument that dates back to antiquity, in the service of merchants and entrepreneurs, whose business purpose is to provide some of these goods and / or technological innovations for the operation and improvement of the company and economic activity. It is therefore of major interest the study and analysis concerning the legal nature of the lease in the Colombian legal system; if it is true that the figure is universal, ie, on which there is an important development in international trade law and private contractual comparative and international law, there are certain peculiarities or specificities in the Colombian domestic law that is worth examining in the light of the law, doctrine and local jurisprudence. Although it is not possible at this contractual as well as everyone else away and make a clean sweep of the conceptual and doctrinal developments on the lease and its legal nature, it is feasible to analyze the particularities of the Colombian domestic law; in other words, make a kind of legal glocalization (ULRICH BECK, 1998); ie without taking away from the concepts and universal legal criteria (Ottawa Convention, model laws, international treaties) are transplants and implement tight legal criteria, according to the needs and legal reality Colombian (cfr. BONILLA MALDONADO, 2009 equally, Harold J. Berman, 1996).

This is the central fundamental aim of this research, that is, what is the legal nature of the lease, how developed in Colombia. From this analysis it is that the lease is a contract of adhesion and, from this perspective, the study of dominant position in the leasing contract is covered by the leasing company. These concepts are essential, vital if you will, for understanding the legal nature of the lease. For this purpose I have chosen to start with the concept of leasing, the first element of the legal nature and functional legal structure of leasing; Then I go into the features 
and elements of the lease, the transit of the economic function of the social function of the figure in the context of a humanized or human face global capitalism as called Stiglitz (2007, pp. $429 \mathrm{ff}$ ) of the need to introduce in the Colombian law injury as invalidating the consent to balance the contractual relationship, the fact that the lease is a contract of adhesion and no free discussion, that is, consensual, as well as legal responsibilities for the parties generated by illicit object and cause. These are core issues in the analysis of the legal concept of leasing, and through its review is intended to present a different, critical and purposeful vision of this type of contract, which according to many is decanted and requires further analysis; Yet here this theory or doctrinal thesis widely accepted in our environment is demystified.

\section{KEYWORDS}

Leasing contract, legal nature of leasing, features and elements of the lease, atypical business, contract of adhesion.

\section{INTRODUCCIÒN}

Las empresas requieren de instrumentos jurídicos y económicos para poder desarrollar su objeto social. Desde el punto de vista mercantil se necesitan recursos (capital, trabajo, conocimiento, innovaciones tecnológicas) para el cumplimiento de las actividades económicas previstas en los estatutos sociales; $y$, desde la perspectiva jurídica, es menester acudir al uso de diversas figuras jurídicas para los mismos propósitos. Lo primero se hace con la obtención de recursos internos (socios) o externos (bancos y prestamistas - crédito), o con el uso y maximización de los recursos existentes. Lo segundo se realiza mediante el uso de figuras jurídicas que permitan dinamizar la actividad mercantil de la empresa. Así, pues, en la estructura empresarial y de negocios se encuentran los contratos de leasing, por medio de los cuales las empresas pueden acceder a maquinaria, equipos y financiamiento para solucionar sus problemas logísticos, 
mejorar su oferta de bienes y servicios y modernizar su infraestructura tecnológica. Por consiguiente, el contrato de leasing se erige en un mecanismo jurídicoeconómico para la obtención de diversos recursos para la empresa de amplia difusión en el comercio internacional ${ }^{3}$. Empresa, capital y contratos son conceptos que se encuentran íntimamente vinculados entre sí, y que contribuyen en la operatividad y competitividad de la empresa.

El contrato de leasing "otorga la utilización de un bien con la finalidad de financiar su adquisición. En esta idea, algunos autores ponen el acento en el carácter locativo del contrato; otros en la financiación de la adquisición de dichos bienes por los consumidores, pero la gran mayoría de la doctrina sostiene el carácter inescindible de unos y otros aspectos, determinando el carácter unívoco y complejo del contrato" (ACQUARONE y EMBÓN, 2004, pp. 30 -31).

\footnotetext{
3"Fue a fines de los años cincuenta y en los primeros años de las década del sesenta cuando el leasing obtuvo en Estados Unidos de Norteamérica una general aceptación por parte de las grandes corporaciones, servicios públicos, bancos de institucionales gubernamentales, dando lugar al mismo tiempo a la formación de las primeras compañías que pasaron a tener un rol similar al que cubrían hasta ese entonces los bancos e instituciones financieras, si bien diferían respecto a estos entes en cuanto a que adquirían los equipos y posteriormente los daban en arrendamiento a sus clientes, en lugar de simplemente otorgar créditos para que después el cliente adquiera el bien. En los años indicados nació en San Francisco la UnitedStates Leasing Corporation, la cual no sólo se desarrolló en su país, sino que se extendió a Europa y el Lejano Oriente, dando nacimiento a compañías extranjeras como la Mercantile Leasing en el Reino Unido en 1960, la Deutsche Leasing en la República Federal Alemana en 1962 y la Orient Leasing en Japón en 1962.

"Los años 70 y principios de los 80 marcan el periodo de crecimiento más rápido en el ámbito mundial. Es así como en Estados Unidos el monto de nuevos equipos en leasing se eleva de US \$ 15 billones en 1975 a US $\$ 37$ billones en 1980, a US $\$ 61$ billones en 1983 y a US $\$ 100$ billones en 1987. Estas cifras señalan que la actividad del leasing ha contribuido aproximadamente al $29 \%$ de la instalación de plantas y equipos adquiridos por los diferentes negocios en el país de referencia. En lo que respecta a Europa Occidental, las empresas agrupadas en la Federación Europea de Compañías de Equipamiento de Leasing (LEASEEUROPE), que agrupa a más de 600 empresas de leasing que representan cerca del $80 \%$ de la industria de leasing financiero en 16 países, en el año 1972 compraron equipos por US $\$ 1,78$ billón, por US $\$ 10,35$ billones en 1980 y por US $\$ 24,7$ billones en $1985(\ldots) "$. Y así, las cifras han aumentado en todos los países y continentes (ORTUZAR SOLAR, 1990, pp. $13-15)$.
} 
Entonces, el contrato de leasing surgió como un mecanismo o instrumento jurídico y financiero para satisfacer las necesidades económicas de los empresarios, para poder ejecutar proyectos de diferente naturaleza, verbigracia, de infraestructura y obras, tecnología industrial, servicios, entre otros. Así, por ejemplo, una compañía puede requerir de una costosa máquina para aumentar la producción o para mejorar (benchmark) el funcionamiento y los procesos productivos. Si el empresario no cuenta con los recursos para cumplir dichos objetivos, el contrato de leasing se instituye en la operación de negocios más apropiada y eficiente para la obtención de los mismos.

Antes, los empresarios debían ser los propietarios de los factores de producción (tierra, trabajo, capital y conocimiento), de los medios de producción. Otrora, el empresario debía disponer de los medios de producción para desarrollar su actividad mercantil; sin embargo, mediante este instrumento jurídico-financiero ya no es necesario que el empresario sea el titular de los medios de producción, pues la maquinaria, los equipos, la fábrica, esto es, los bienes muebles e inmuebles pueden ser explotados por la compañía mediante los diversos tipos de leasing (financiero, operativo, de intermediación, de mantenimiento, leasing-back, inmobiliario, entre otros). Ello facilita la creación de empresas y la operatividad de las mismas $y$, por ende, fomenta el crecimiento empresarial en los términos señalados por el artículo 333 de la Constitución Política de 1991.

Con razón afirma ÁLVAREZ-CORREA (1991, pp. 256 - 257):

El leasing tiene por finalidad obviar las dificultades para obtener capitales de trabajo, y mantenerse al día respecto de los adelantos tecnológicos que hacen obsoletos a la maquinaria y a los equipos. Permite sustituir el uso de recursos para la adquisición de la maquinaria y así liberar esos fondos para un capital de trabajo. Al mismo tiempo, se podrán renovar la maquinaria y los equipos, y en algunos casos surtirán ventajas fiscales. Así mismo, 
tratándose de inmuebles 0 de muebles muy costosos (buques 0 aeronaves), permite obtener su uso sin desembolsar capitales importantes.

Lo anterior involucra tres aspectos particulares: los contables, los fiscales y los financieros. En primer lugar, desde el punto de vista contable, el usuario arrendatario no hace figurar la operación expresamente en el balance. Los materiales recibidos no aparecen en el activo, y la deuda contraída no aparece en el pasivo. De esta manera no aumentan sus inmovilizaciones ni su pasivo, mejorando ellos sus coeficientes financieros.

Sin embargo, contiene un riesgo para los terceros, que sólo podrán inferir la existencia del contrato de leasing en las cuentas de los ingresos y egresos. Por esta razón, el contrato debería someterse a condiciones y a disposiciones estrictas.

En segundo lugar, en un sistema legislativo donde no exista un límite fiscal respecto del monto máximo de los intereses deducibles por obtención de créditos, sin restricción sobre el monto pagado en arriendos, habría una ventaja tributaria al optar por un leasing antes de obtener un crédito para la adquisición directa de los bienes.

Finalmente, el leasing es ventajoso para el usuario por cuanto podrá utilizar el bien sin aportar una suma a la financiación, aunque para la sociedad de leasing podría haber un riesgo en la incapacidad financiera del usuario, o en la enajenación por éste de los bienes objeto de leasing.

En definitiva, el contrato de leasing transformó los fundamentos jurídicos y económicos tradicionales concernientes a la organización empresarial; es un mecanismo de financiación empresarial para la obtención de recursos y facilita el desarrollo empresarial y de los negocios. 


\section{NATURALEZA JURÍDICA DEL CONTRATO DE LEASING}

Una pregunta que se suele formular por algunas personas que se inician en materia contractual, es la concerniente al significado y alcance del concepto de naturaleza jurídica en la contratación y, en particular, en el ámbito de los negocios jurídicos de leasing. Para toda la doctrina, sin excepción a nivel nacional e internacional, es indiscutible, indudable, que el concepto de naturaleza jurídica atañe a los elementos y características de los contratos, y no a otra cosa, es un concepto admitido, aceptado por la doctrina universal, que no admite ambigüedades, ni mucho menos se trata de un concepto anfibológico; es diáfano. Por ello, esta investigación se centra en el análisis y en el estudio de los elementos y características del contrato de leasing, o sea, en la naturaleza jurídica, si es una especie de arrendamiento o compraventa, si se perfecciona por el simple acuerdo de voluntades o mediante el cumplimiento de una serie de formalidades específicas; a esto se refiere la naturaleza jurídica. Así las cosas, esta investigación aborda la naturaleza jurídica del contrato de leasing en Colombia, sin desconocer los aportes doctrinales y legales del derecho mercantil internacional. Los conceptos legales, jurisprudenciales y doctrinales en materia del contrato de leasing a nivel universal, esto es, los que se han elaborado a nivel global, han permeado la doctrina local, el derecho mercantil nacional; aquí en Colombia no nos podemos inventar las categorías del derecho contractual y del derecho de los negocios, sino que, por el contrario, debemos adoptar, acoger, trasplantar jurídicamente (Al respecto, cfr. BONILLA MALDONADO, 2009), si se quiere, los conceptos y criterios universales, para adaptarlos a nuestro derecho interno. Esa es la función de la lexmercatoria, de las leyes modelo, de la costumbre mercantil internacional, del derecho de los negocios del siglo XXI. De ahí que se hable de la aldea global, es decir, de un mundo y de un derecho contractual interconectado e interdependiente (RAVASSA MORENO, 2004;

OVIEDO ALBÁN, 2010; FERNÁNDEZ DE LA GÁNDARA y CALVO CARAVACA, 1995). En este orden de consideraciones, esta investigación comienza por abordar el concepto del contrato de leasing, luego se adentra en sus características y 
principales elementos y, por último, al concluir que se trata de un contrato de adhesión, se analizan y examinan en detalle los problemas que genera la posición de dominio y su correlación con el hecho de que se trata de un negocio jurídico de adhesión. Precisamente, el artículo 1501 del Código Civil colombiano nos brinda una aproximación bastante certera de la naturaleza jurídica de los contratos en general, que como es obvio, se aplica a este contrato atípico. Ciertamente, la norma anteriormente enunciada, dice: "Cosas esenciales, accidentales y de la naturaleza de los contratos. Se distinguen en cada contrato las cosas que son de su esencia, las que son de su naturaleza, y las puramente accidentales. Son de la esencia de un contrato aquellas cosas sin las cuales, o no produce efecto alguno, o degeneran en otro contrato diferente; son de la naturaleza de un contrato las que no siendo esenciales en él, se entienden pertenecerle, sin necesidad de una cláusula especial; y son accidentales a un contrato aquellas que ni esencial ni naturalmente le pertenecen, y que se le agregan por medio de cláusulas especiales"4.

Así las cosas, procedemos a examinar la naturaleza jurídica del contrato de leasing en Colombia, con base en el derecho contractual internacional, a partir de lo anteriormente esbozado.

${ }^{4}$ En el mismo sentido respecto de la naturaleza jurídica de los contratos: ARRUBLA PAUCAR, 1998; PEÑA NOSSA, 2015; LÓPEZ GUZMÁN, 2007; ESCOBAR SANÍN, 1990; TAMAYO LOMBANA, 1997. 


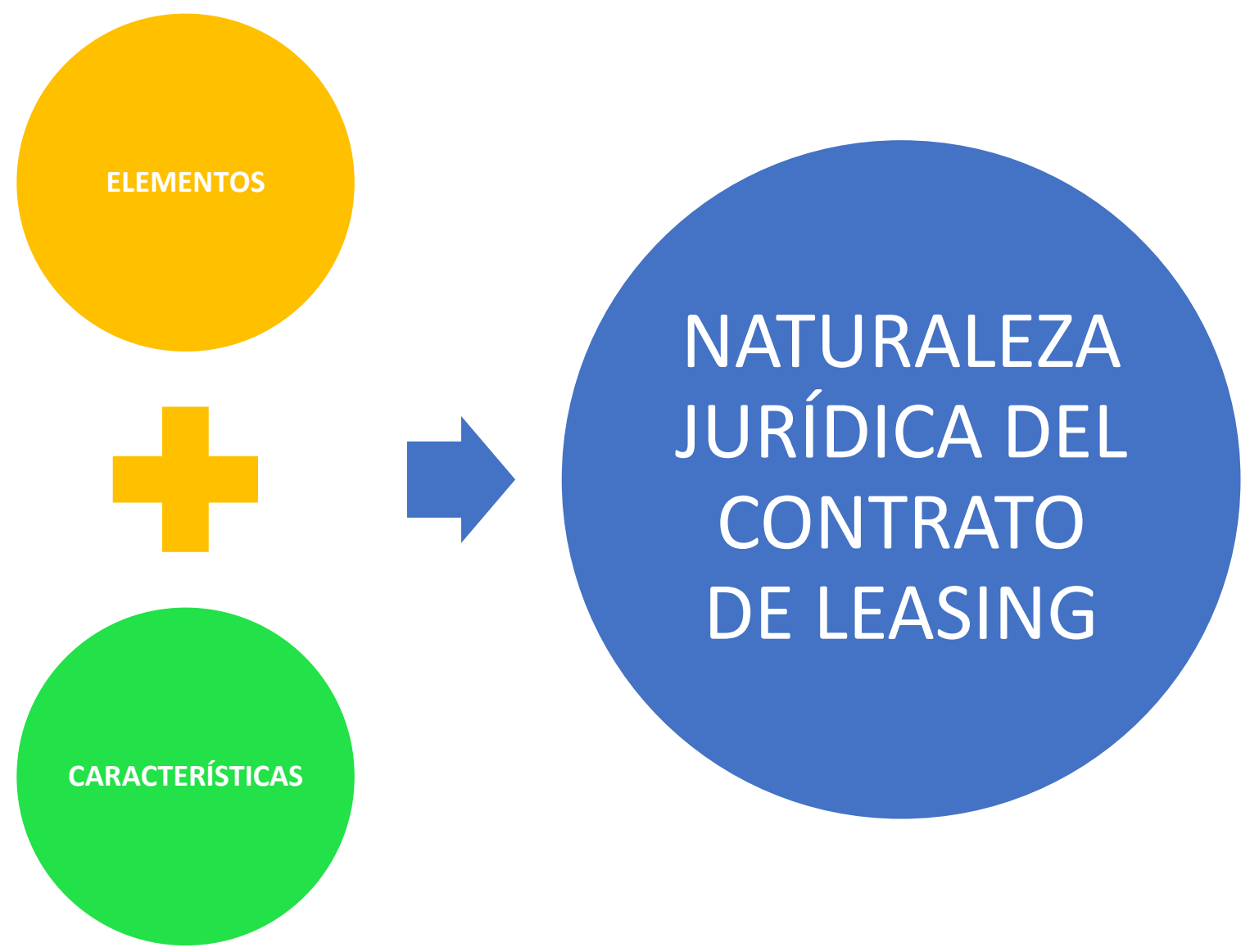

\section{METODOLOGÍA}

Para la elaboración del presente trabajo de investigación se diseñó una metodología con un enfoque cualitativo, puesto que el análisis jurídico sobre la estructura y la naturaleza jurídica del contrato de leasing se deben realizar desde una perspectiva conceptual, examinando con detalle cada uno de sus elementos, diferenciándolos y desmenuzándolos con visión crítica. Así mismo, como estrategia metodológica se propone mediante el método deductivo ${ }^{5}$ analizar el

${ }^{5}$ De conceptos y categorías jurídicas generales y globales del derecho mercantil a conceptos y categorías jurídicas específicas, para Colombia, para el contrato de leasing a nivel local. 
leasing desde la perspectiva jurídica y empresarial, a partir de su naturaleza jurídica (elementos, características, función económica y social) y de la posición de dominio que ejercen las compañías de leasing sobre la parte débil en el contrato: el empresario que solicita el servicio de leasing. Por consiguiente, se desarrolla el tema y el problema de lo general a lo particular, con el propósito de presentar críticas y plantear soluciones a la problemática de la posición dominante y al clausulado abusivo en el contrato. Para cumplir con lo anterior, se estudia el leasing en dos capítulos, así: (i) en el primero, se aborda el concepto o noción del leasing y sus elementos estructurales, requisitos de validez y características; (ii) Luego, en el capítulo II, además de algunos elementos esenciales del contrato, la investigación se adentra en el problema de la posición dominante y en la existencia de cláusulas abusivas dentro del contrato, con objeto de plantear que el contrato no es de libre discusión sino de adhesión, habida cuenta de la posición privilegiada de la empresa de leasing. Para terminar, se presentan las conclusiones de rigor.

En la siguiente gráfica se explica la metodología adoptada. El estudio y análisis sobre la naturaleza jurídica del contrato de leasing no se refiere a ésta como un compartimento estanco, aislado, como si al hablar o estudiar la naturaleza jurídica, éste fuese un concepto único, separado, autónomo, independiente si se quiere; no, por el contrario, hablar de la naturaleza jurídica es referirse a cada uno de los elementos y características del contrato de leasing, y a partir de allí, es decir, del análisis de cada uno de estos elementos y de las críticas a ellos, es que se efectúa el desarrollo metodológico de la estructura jurídica y de la naturaleza jurídica del contrato de leasing. Es como disertar sobre los derechos humanos fundamentales en la Constitución de 1991; ese es el concepto genérico, el epígrafe, pero para desarrollarlo metodológicamente hay que desglosar cada uno de ellos, verbigracia, el derecho a la vida, a la igualdad, al debido proceso, a la dignidad humana, entre otros. Así, pues, es un estudio y análisis desde la complejidad, desde el contexto, con visión holística, panorámica de cada uno de sus elementos y características, pues son éstos, y no otros los componentes que 
integran el estudio sobre la naturaleza jurídica del contrato de leasing, y la comprensión y la discusión jurídica se deben abordar una vez se hayan expuesto todos sus elementos y características, en visión de conjunto, en un examen desde la complejidad del derecho de los negocios de hoy, del derecho contractual en la era de la globalización, como una especie de sistema escalar (Cfr. EDGAR MORIN6; VELILLA MORENO, 20017; LÓPEZ GUZMÁN, 2007). Sin esta ruta o carta de navegación metodológica el examen de la naturaleza jurídica de cualquier contrato es imposible, es ilógico, no se puede abordar, al margen del sistema jurídico en que se realice (Civil law o Commonlaw).

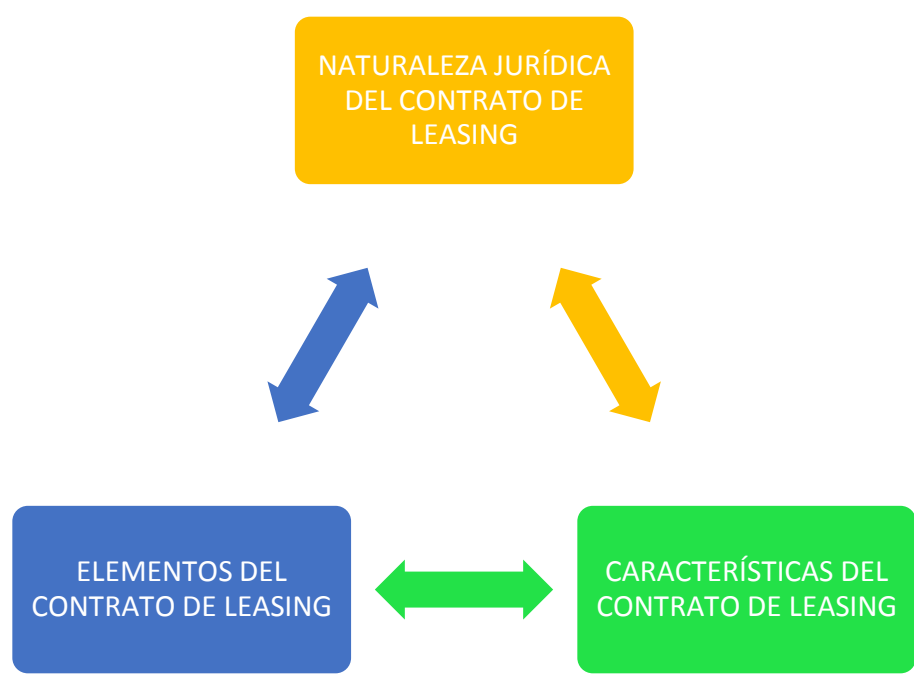

6"Lo único sustantivamente complejo es la realidad misma, que desborda el pensamiento y de la cual no podemos tener ningún conocimiento directo, sino fenoménico. Propone un "método", como camino articulador o de autoconstrucción de conocimiento hacia el "pensamiento complejo". Una auto organización de conocimiento que vincule lo desvinculado, llamada "pensamiento complejo" no porque realmente sea compleja, sino porque está orientada hacia lo complejo y nunca lo intenta reducir. O en otras palabras "un anti-método en el que la ignorancia, la incertidumbre, y la confusión se conviertan en virtudes", en signos precursores de la complejidad" (ÉDGAR MORIN, El método II: La vida de la vida. Cátedra. Madrid. 1983, p. 29).

${ }^{7}$ MARCO ANTONIO VELILLA MORENO (Introducción al derecho de los negocios, Bogotá, Editorial Ibáñez, 2001), nos presenta un análisis sobre la incidencia del pensamiento complejo en el ámbito del derecho contractual y de los negocios. Dicho autor explica cómo los contratos y los negocios contemporáneos deben ser analizados y estudiados no solo desde una perspectiva exclusivamente jurídica, sino compleja, integral, que abarque igualmente los aspectos empresariales y económicos que dinamizan la actividad contractual en el mundo globalizado de hoy. 


\section{CONCEPTO}

En el examen sobre la naturaleza jurídica lo primero que se debe examinar para el desarrollo del contrato de leasing es, sin duda, el concepto, la definición o noción que la doctrina ha explicado o ha planteado, pues a partir de ella es que se desarrollan, como es sabido por todos, los elementos, características $y$, en concreto, la naturaleza jurídica del contrato de leasing en el derecho colombiano ${ }^{8}$. De lo contrario, sin definición, sin una noción al respecto, es imposible entrar a desarrollar y desglosar la naturaleza jurídica de éste y de sus características, ya que a partir de ella es que se desdoblan y singularizan los aspectos esenciales de la naturaleza jurídica; sin un escrutinio sobre la definición o noción del leasing, se hace imposible el estudio sobre su naturaleza jurídica. De ahí que se empiece por una noción, y a partir de esta metodología analítica se desarrollen los aspectos concernientes al problema fundamental planteado al comienzo de esta investigación. Entonces, sea lo primero, adentrarse en la noción de leasing y en la conveniencia o no de adoptar una en particular.

En mi criterio, es un error adentrarse en el problema de las definiciones, máxime por cuanto la traducción del término al español no logra satisfacer ni explicar integralmente el alcance y contenido de la operación de leasing. A ello se añade el hecho de que en el derecho de contratos actual se obvian las definiciones,

8 "Arrendamiento. Es una de las traducciones más utilizadas para el denominado leasing, aunque se puede emplear la frase <<arrendamiento financiero〉>. Específicamente, se refiere a un contrato de arrendamiento civil hecho para financiar algunos bienes sin la necesidad de erogar grandes cantidades iniciales. Además, establece la posibilidad de comprar o devolver el bien al término del plazo pactado.

"Por lo general, el leasing es utilizado para adquirir bienes o activos (maquinarias) que sirven para la producción de bienes y servicios. En la operación, la empresa que otorga el arrendamiento (arrendadora) compra el artículo o la propiedad y la cede en uso (o alquila) a quien la necesite a cambio de un pago periódico, todo establecido en un contrato. En el documento que se firma entre las partes se establece el plazo de la operación" (MORALES CHAVARRÍA, 2013, p. 32). 
procurando armonizar y unificar las instituciones del derecho contractual, y además, por el hecho de que las definiciones se estatizan y no logran avanzar al mismo ritmo de las figuras jurídicas y, por supuesto, de los negocios y operaciones mercantiles. Así, pues, las traducciones no logran ajustarse a las características y función económica del contrato de leasing. De hecho, el artículo 823 del Código de Comercio colombiano se refiere al punto y conviene realizar un análisis preliminar sobre el particular.

La norma citada dispone lo siguiente:

Los términos técnicos o usuales que se emplean en documentos destinados a probar contratos $u$ obligaciones mercantiles, o que se refieran a la ejecución de dichos contratos u obligaciones, se entenderán en el sentido natural y obvio que tengan en el idioma castellano.

Cuando se hayan utilizado varios idiomas, se entenderán dichos términos en el sentido que tengan en castellano, si este idioma fue usado; en su defecto, se estará a la versión española que más se acerque al significado del texto original.

El sentido o significado de que trata este artículo es el jurídico que tenga el término o locución en el respectivo idioma, o el técnico que le dé la ciencia $o$ arte a que pertenezca o finalmente el sentido natural y obvio del idioma a que corresponda.

Si se analiza con detenimiento el artículo 823 del Código de Comercio colombiano, se pueden deducir varios criterios al respecto: como primera medida, de la primera parte de la norma se puede concluir sin ambages que para definir el contrato de leasing hay que atenerse al sentido que tiene en el idioma castellano; de otra parte, la segunda parte de la norma está orientada en la misma dirección; sin embargo, la última parte de la disposición se acerca más a la realidad del 
comercio y los negocios cuando se indica que el significado que se le debe dar al leasing es el técnico que le confiere la dinámica de los negocios y operaciones mercantiles. Si bien es cierto que la primera parte de la disposición está orientada a que los términos jurídicos sobre los contratos y negocios expresados en otro idioma se les debe dar el significado que tienen en el idioma castellano, lo cierto es que el negocio de leasing está referido es a una operación mercantil mediante la cual se le permite a un empresario acceder a maquinaria o equipos a cambio del pago de un canon que se paga en forma periódica.

$Y$ es éste el sentido o significado en que verdaderamente se debe entender el término al que venimos aludiendo. La última parte del artículo, sin duda, constituye, a nuestro juicio, un desarrollo del análisis económico del derecho, que atiende más a la realdad empresarial, a la eficiencia, a los costes de transacción, al entorno económico y de los negocios, a la dinámica del mercado, que al tenor literal de las palabras. Es un método de interpretación complementario de análisis económico de los contratos y de las normas, que permite al jurista y al operador económico tener una visión más clara, concreta y práctica de los términos usados en el ámbito de los negocios (Véase POSNER, 2000; VICENT CHULIÁ, 2001, p. 63); de ahí que la última parte de la disposición que se analiza, pensamos que acoge esta tendencia o método de interpretación de los contratos.

Por ello, es más sensato y acorde con el derecho contractual actual evitar a toda costa las definiciones, así como la mera traducción literal sin analizar las figuras jurídicas en su contexto y desde la perspectiva de la función económica que cumplen dentro del mercado. Así las cosas, cualquier definición siempre peca de incompleta y obsoleta, dado que las figuras jurídicas van evolucionando, se van adaptando a las condiciones del mercado y los negocios.

Enseguida traemos a colación algunas definiciones para realizar el análisis correspondiente: 
Para CARLOS ALBERTO GHERSI (2006, T 2, p. 164),

El concepto a priori que podemos enunciar es que se trata de un método de financiación, por el cual el acreedor (vendedor-locador) financia al deudor (adquirente-arrendatario) a los efectos de posibilitar la compra de un bien (generalmente capital o al menos durable), de tal forma que el deudor reconoce a favor del acreedor un pago periódico (mensual, trimestral, etc.), que puede caracterizarse como canon locativo o como parte de pago del precio si acepta la opción de compra, debiendo en ese momento jurídicamente acepta la oferta de venta, transformando la operatoria de locación a compraventa - pagar un valor residual para completar el precio (total) de venta.

En la sistemática de la economía capitalista es una forma de adquirir activos fijos sin compromiso de capital inicial (por falta de liquidez o uso alternativo de su propio capital como mayor beneficio); además, permite desde la contabilidad de la empresa, que su balance no se vea comprometido por un endeudamiento (relación total de la deuda en el pasivo de la empresa), e impositivamente le permite cargar a costos el pago del arrendamiento.

Como se observa, la definición es demasiado aparatosa, complicada, compleja, y no permite deducir con claridad, con facilidad el alcance y contenido de la figura, no obstante que el autor hace una descripción detallada de la operación. Se trata de una definición muy extensa y alambicada, que a la larga dificulta en grado sumo la comprensión de la figura para los operadores económicos.

Por su parte, PEÑA NOSSA (2012, p. 504) expresa lo siguiente acerca dela figura jurídica que venimos estudiando: 
Es un contrato mediante el cual una parte entrega a otra un activo productivo para su uso y goce, a cambio de un canon, durante un plazo convenido, a cuyo vencimiento el bien se restituye a su propietario o se transfiere al locatario, si este decide ejercer la opción de adquisición que se pacta a su favor.

La definición anteriormente transcrita si bien es cierto que se caracteriza por ser más breve, logra explicar mejor el concepto de leasing, con la ventaja de que no incurre en el mismo error en que insiste la mayoría de la doctrina al confundir el leasing con el contrato de arrendamiento. Habida cuenta del significado del término en el idioma castellano, la mayoría de la doctrina trata de encajar la definición, la naturaleza y los efectos jurídicos dentro del contrato de arrendamiento. Por tal razón, cuando se habla de la naturaleza jurídica del leasing se suele afirmar que es un contrato que guarda estrecha relación con el arrendamiento y otras figuras, sin distinguir que se trata de una figura jurídica completamente autónoma ${ }^{9}$,con identidad propia, y que si bien es cierto que mantiene similitudes con otras figuras, debe mantener su independencia. En otras

\footnotetext{
${ }^{9}$ Como es apenas obvio, no se pretende demostrar qué se entiende por naturaleza jurídica del contrato de leasing, lo cual es completamente absurdo, dado que se trata de un concepto indiscutido, demostrado, universal, sino de discutir en el marco de esa naturaleza jurídica sus características y elementos, es decir, si las características y elementos que lo configuran tienen aspectos comunes o diferenciales con otros negocios jurídicos, verbigracia, el contrato de arrendamiento, el contrato de compraventa con pacto de retroventa, entre otros. A partir de este análisis y de esta discusión, es que se definen y se materializa la verdadera naturaleza jurídica del contrato de leasing: distinguiendo los elementos inherentes a este contrato y a esta figura jurídica, sin confundirlos o asociarlos con figuras jurídicas similares. ¿Por qué? Porque al contrato de leasing se le deben aplicar las normas del negocio jurídico del leasing, la ley sobre el leasing, las costumbres mercantiles sobre el leasing, los tratados internacionales sobre el leasing, y no las normas nacionales sobre el contrato de arrendamiento, o el Código Civil. Al descubrir y escudriñar en los elementos y características del contrato de leasing, entramos en el problema de la aplicación de las fuentes del derecho mercantil, en el orden de precedencia de las fuentes. No es lo mismo aplicar a un vacío jurídico contractual el Código Civil que un tratado internacional sobre el leasing. El análisis de sus elementos y características nos conduce al estudio de las fuentes y su aplicación e interpretación en los vacíos subyacentes en el contrato de leasing.
} 
palabras, el leasing es un contrato atípico, con características únicas, sui géneris, producto de las actividades, negocios y operaciones mercantiles que los comerciantes celebran en el mercado para el funcionamiento y mejoramiento de su empresa y su actividad económica.

La Federación Colombiana de Compañías de Leasing FEDELEASING (Manual Jurídico del Leasing, 2010, p. 15) lo define en los términos que se trascriben enseguida:

En sentido amplio, el leasing es un contrato mediante el cual una parte entrega a la otra un activo para su uso y goce, a cabio de un canon periódico, durante un plazo convenido, a cuyo vencimiento el bien se restituye a su propietario, o se transfiere al usuario si éste último decide ejercer una opción de adquisición que, generalmente, se pacta a su favor.

La denominación "leasing" es una palabra en inglés, que viene del verbo "tolease"que significa "tomar o dar e arrendamiento", pero que no recoge de manera suficiente la complejidad del contrato, que es especial y diferente al simple arriendo; sin embargo, la legislación y doctrina mundial, incluida Colombia, lo ha denominado leasing.

En la misma línea de pensamiento, el decreto 913 de 1993 lo define en su artículo segundo de la siguiente manera:

Entiéndase por operación de arrendamiento financiero la entrega, a título de arrendamiento, de bienes adquiridos para el efecto, financiando su uso y goce a cambio del pago de cánones que recibirá durante un plazo determinado, pactándose para el arrendatario la facultad de ejercer al final del periodo una opción de compra. 
"En el anterior orden de ideas, debe estarse en primer lugar a lo convenido por las partes en el respectivo contrato en lo atinente a constitución, desarrollo y cumplimiento, siempre y cuando las cláusulas contractuales no contravengan el orden público y las buenas costumbres" (DURÁN BOHÓRQUEZ, 2004, p. 23).

Si se observa con atención, las definiciones anteriores describen la operación, el alcance y su función económica en el mercado. Aunque, como se ha señalado con anterioridad, lo más apropiado es evitar las definiciones, los conceptos precisos y sumamente detallados, pues siempre estarán incompletos y, como es sabido, no van al mismo ritmo de los acontecimientos comerciales, económicos y de los negocios entre comerciantes y empresarios. He ahí el peligro de las definiciones y de los conceptos. La argumentación precedente explica por qué en los tratados comerciales internacionales, leyes modelo $y$, en general, en las normas internacionales que regulan la contratación internacional, el arbitraje comercial, la insolvencia empresarial, el comercio electrónico, el transporte multimodal, la conciliación internacional, se prescinde de las definiciones y del marco de los conceptos. Es en esta dirección que ahora se desarrolla el derecho contractual contemporáneo, atendiendo más a la función económica, a la operatividad y a la dinámica de las figuras jurídicas que al significado puramente literal.

\section{FUNCIÓN ECONÓMICA}

Como es lógico, dentro del estudio y análisis de la estructura y naturaleza jurídica del leasing es menester revisar la función económica de la figura, porque sin ella no es posible conocer el verdadero sentido y alcance de la naturaleza jurídica del contrato. Es un hilo conductor que está íntimamente ligado: la definición o noción enuncia los aspectos esenciales del contrato; luego, en la función económica se detalla el fin, lo cual es relevante y fundamental dentro de la estructura jurídicafuncional y, por ende, principal para la comprensión de la naturaleza jurídica. Por último, dentro de esta lógica discursiva sobre la naturaleza jurídica del leasing, se estudian sus elementos y características para poder llegar a presentar propuestas 
y conclusiones sobre el particular; sin esta secuencia lógica sobre el contrato de leasing no es posible indagar ni desarrollar el aspecto central de nuestra investigación. Por tanto, enseguida se examina lo elativo a la función económica, esto es, el tránsito de la función económica hacia la función social de este contrato, dada la mega tendencia jurídica del derecho privado contemporáneo, que apunta más hacia una función social que económica del leasing, teniendo en cuenta el crecimiento de las empresas sociales en la economía moderna ${ }^{10}$.

Respecto de la función económica, indica FARINA (1999):

La necesidad de equipamiento de las empresas debe conciliarse con la necesidad cada vez mayor de un capital circulante, tratando de evitar un gran endeudamiento que puede tener una consecuencia paralizante. Los avances tecnológicos de nuestra época determinan la obsolescencia- en poco tiempo- de equipo y maquinarias, lo que impone la necesidad del reequipamiento permanente de la empresa, para no perder laclientela y el mercado. El leasing aparece así como el instrumento adecuado para lograr ese reequipamiento que, generalmente, necesita de grandes capitales que no pueden sustraerse del proceso productivo, pues permite reemplazar equipos obsoletos o ya envejecidos sin acudir a la compraventa, sino a esta original forma de locación que es el leasing.

Y en el mismo orden de consideraciones manifiesta GHERSI (1998):

En la dinámica de la economía capitalista es indudable que las nuevas formas de financiamiento adquieren una marcada relevancia para la

\footnotetext{
${ }^{10}$ ¿Cuándo conviene el leasing? Cuando el comprador no dispone de la suficiente solvencia para adquirir maquinarias y equipos. Igualmente, por motivos fiscales, a fin de reducir el pago de impuestos para la empresa. Además de que la financiación tiene un manejo contable que beneficia al empresario (Véase Escuela de Negocios, Otras técnicas de Financiación del Comercio Internacional: el leasing, 2012, p. 3).
} 
adquisición y renovación de tecnología en bienes durables y de capital; es una nueva metodología de acumulación de capital para los grupos económicos. Ante la irreversible situación de esta fase de la economía capitalista, la atención del jurista debe estar enfocada en dos sentidos.

El primero ya lo enunciamos al enmarcar esta tipología estructural dentro de la contratación por adhesión - lo que implica la revisión de las cláusulas impuestas por el poder económico al predisponerlas -; el segundo es revisar la operatoria económica - como contrato de adquisición y metodología y financiamiento para resguardar el principio rector de la equivalencia de las prestaciones, aun cuando admitimos la complejidad del problema, debido a la mala formación económica de los abogados.

En la sistemática de la economía capitalista es una forma de adquirir activos fijos sin compromiso de capital inicial (por falta de liquidez o uso alternativo de su propio capital como mayor beneficio); además permite desde la contabilidad de la empresa, que su balance no se vea comprometido por un endeudamiento (relación total de la deuda en el pasivo de la empresa), e impositivamente le permite cargar a costos el pago del arrendamiento.

Sin embargo, debemos alertar que esta metodología, en cuanto a su óptica económica, suele ser más onerosa para la empresa adquirente, pues el arrendador o leaser obtiene los recursos - para el financiamiento - de un ente bancario (el banco es un captador de recursos del público ahorrista o inversionista), pro la realidad es que la empresa adquirente difícilmente pueda obtenerlo, por diversas circunstancias (patrimonio o activos insuficientes, carencia de trayectoria en plaza...).

En lo atinente a la tecnología, tiene un doble carácter, pues en un sentido el adquirente se asegura el recambio constante, con lo cual permite a su 
empresa gozar de la más avanzada tecnología, lo que favorece su competitividad y productividad en el mercado; pero en otro sentido está atada o cautiva a una determinada línea tecnológica y a las exigencias de la empresa proveedora, aun cuando en la actualidad se ha superado bastante el tema por el desarrollo de las denominadas tecnologías compatibles (aunque se sigue manteniendo cautivo al cliente adquirente mediante otros recursos, verbigracia, servicios adicionales, seguros, repuestos, accesorios, etc...).

Los autores presentan diversos conceptos en torno de la función económica del leasing. Respecto de este punto, consideramos que la función económica del leasing alude a lo siguiente: a) Necesidad de modernizar la empresa, el establecimiento y los equipos del empresario; b) Mejoramiento de los procesos productivos; c) Innovación tecnológica, pues a través del contrato de leasing se introducen nuevas tecnologías a la empresa, se permite la explotación de patentes y know-how y de equipos de alta tecnología en beneficio de la empresa; d) Optimización de los servicios de la empresa; e) Facilitar el desarrollo empresarial y la actividad económica de la compañía. Sin embargo, dado el desarrollo y crecimiento del leasing en los últimos años, y en todas las áreas, el leasing no sólo tiene una función económica dentro de la empresa, sino también una función social. Es decir, que en la actualidad se está migrando de la función económica hacia la función social del leasing en los términos previstos por los artículos 58 y 333 de la Constitución Política de 1991. Ciertamente, la amplia difusión del leasing, su extensión al sector real e inmobiliario, a las nuevas tecnologías en el ámbito empresarial, educativo, del transporte, de las comunicaciones, entre otros, han hecho del leasing una figura jurídica que acompasa las políticas públicas sobre infraestructura y obras, sobre desarrollo empresarial y asistencia social. Los programas relacionados con vivienda, vías, infraestructura, educación, entre otros, destinados al interés general, al bienestar general, utilizan hoy con frecuencia el leasing en sus diversos tipos para llevar a cabo dichos propósitos macroeconómicos. Por tanto, el leasing no solo cumple una función económica 
sino también social, a diferencia de las concepciones tradicionales expuestas por la doctrina (PEÑA NOSSA; ARRUBLA PAUCAR; BONIVENTO FERNÁNDEZ; RODRÍGUEZ AZUERO; GHERSI; RAVASSA MORENO, entre otros), que únicamente lo sitúan en este escenario. Función social, porque la asistencia gubernamental, el interés general y la problemática social y económica global así lo ameritan. Las figuras jurídicas no sólo se deben emplear en beneficio de los empresarios y de los comerciantes, son también de los demás agentes del mercado, y como es lógico, se pueden emplear en el ámbito social, en programas sociales de sumo interés para la comunidad, a fin de conseguir recursos, maquinaria y equipos, sin afectar la estructura, la cultura o la dinámica de las operaciones mercantiles.

Entre tanto, cabe resaltar que la introducción de nuevas tecnologías no sólo se hace en el ámbito empresarial, sino también en el sector educativo, en el escenario cultural y social. Proyectos de suma importancia para la comunidad, tales como la modernización de los centros educativos, proyectos de desarrollo para infraestructura y obras en una comunidad, se pueden llevar a buen término mediante la figura jurídica del leasing; de esta manera, el leasing cumple hoy en el derecho de la contratación del siglo XXI una función social, más que una función económica, merced al hecho de que la globalización ha mutado el modelo capitalista hacia el modelo de capitalismo humanizado. Entonces, es equivocado hablar hoy día de función económica, cuando, por el contrario, se debe hablar es de función social. Esta es nuestra primera crítica sobre la concepción doctrinal del contrato de leasing en Colombia.

\section{EVOLUCIÓN Y DESARROLLO DEL LEASING EN EL DERECHO COLOMBIANO}

En nuestro país la figura jurídica del leasing se remonta hacia los años 70 , como una actividad mercantil libre y autónoma. En aquel periodo las operaciones comerciales de leasing ascendían a los 32 billones de dólares; de manera que se 
trataba de una operación mercantil de profundo impacto en las economías de los industrializados (Estados Unidos, Japón, Reino Unido y Alemania, entre otros ${ }^{11}$. Después de un juicioso análisis, el gobierno colombiano se percata de que la operación de leasing es una actividad financiera, que requería mayor control por parte del Estado, con el propósito de evitar o mitigar los abusos en que pudieran incurrir los particulares que ofrecían este servicio de leasing. Así fue como se expidió el decreto 2059 de 1981, por intermedio del cual se estipuló que las sociedades mercantiles que se dedicaran a las operaciones de leasing quedarían sometidas a la inspección y vigilancia de la Superintendencia de Sociedades, al

\footnotetext{
${ }^{11}$ En Colombia la actividad del leasing tuvo su auge en 1994 y 1995, cuando los activos dados en leasing por las compañías de financiamiento comercial representaban $2.7 \%$ del PIB y $6,5 \%$ de la cartera del sistema financiero. A partir de 1995 empezó su descenso hasta el 2002, fecha desde la cual la actividad se ha venido reactivando, aunque aún sin alcanzar los niveles anteriores a 1995. Además del efecto del ciclo, en buena parte esta contracción se originó en la abolición de los beneficios tributarios en el uso del leasing otorgados a las grandes empresas lo que redujo sustancialmente la utilización de este mecanismo de financiamiento.
}

No obstante, el leasing en Colombia se ha establecido como una opción clara de crédito para el sector productivo. La Encuesta de Opinión Empresarial de Fedesarrollo muestra que el leasing representa un $14,5 \%$ del total de recursos utilizados por las empresas para su expansión, (frente a sólo $2 \%$ para capital de trabajo). Este efecto es aún más claro en el año 2004, donde las empresas esperan financiar su expansión en un $35 \%$ con recursos provenientes del leasing.

En particular, el leasing ha sido un mecanismo de financiamiento especialmente relevante para las pequeñas empresas, incluso con una tendencia creciente en el tiempo. Se resalta la importancia del leasing como fuente de recursos para expansión en las Pymes, ya que dentro del total de recursos para este propósito, el leasing representaba alrededor del $18 \%$ para este tamaño de empresas en 2002 y creció a $41 \%$ según sus planes para 2004. El porcentaje en el caso de las grandes asciende a $10 \%$ en 2002 , y pasa a duplicarse hasta $20 \%$ en 2004 y a $47,4 \%$ en las medianas. Incluso, los análisis muestran que, además, las empresas que planean utilizar el leasing tienen planes más ambiciosos de inversión.

Los resultados de la encuesta realizada en 2004 para este estudio muestran que el uso del leasing seguirá creciendo en forma muy dinámica, en buena medida como resultado de los beneficios tributarios consignados en la pasa reforma tributaria, relacionados con las deducciones de impuesto la renta en el uso del leasing y del IVA a la importación de maquinaria y equipo. En cuanto al impacto del leasing sobre la inversión privada (tasa de penetración) este indicador alcanzó un valor máximo de 7,1\% en 1996, se mantuvo cercano a 5\% hasta 1999 y se ubicó en 3,7\% en 2002" (ANIF-FEDESARROLLO, El leasing en Colombia: diagnóstico e impacto sobre la inversión y el crecimiento). 
igual que cualquier otra sociedad comercial de las reguladas por el estatuto mercantil.

Con el advenimiento de la crisis financiera de 1982, el gobierno nacional estableció que las compañías de leasing no podían captar en forma masiva y habitual dineros provenientes del ahorro privado, mediante el decreto 2920 del mismo año. Este decreto se expidió merced a la declaratoria de emergencia económica, de acuerdo a lo que preceptuaba el artículo 122 de la Constitución de 1886. De todas maneras, la Superintendencia Bancaria, o Superintendencia Financiera, autorizó a las compañías financieras a prestar recursos a las empresas de leasing, con lo cual se incrementaron las operaciones de leasing en las principales ciudades del país.

En 1984 el gobierno nacional expidió la ley 74 por medio de la cual se dictaminó que la vigilancia de las compañías de leasing debía hacerse por conducto de la Superintendencia Bancaria y conforme a lo dispuesto por la ley 45 de 1923. Así las cosas, el Ministerio de Hacienda y Crédito Público reguló mediante el decreto 3039 de 1989 la ley 45 de 1923, con el propósito de legislar sobre las operaciones de leasing financiero y controlar dicha actividad en aras de proteger los derechos de los consumidores y usuarios. Entre tanto, la Superintendencia Bancaria, a través de varios actos administrativos, verbigracia, la Resolución 4460 de 1989 se encargó de organizar y reglamentar el negocio del leasing en Colombia.

En el decenio de los años 90 se profirió la ley 45, con la finalidad de equiparar a las compañías de leasing con las sociedades de servicios financieros, sociedades fiduciarias, comisionistas de bolsa, almacenes generales de depósito y sociedades administradoras de fondos de pensiones y cesantías, con lo cual adquirieron la misma categoría que las demás empresas del sector financiero. Más tarde, se expidieron varios decretos de carácter tributario, tendientes a precisar las operaciones de leasing, diferenciándola del arrendamiento puro, de la venta a plazos y del crédito con el sistema financiero, poniendo énfasis en el hecho de que 
la opción de compra en el leasing el valor comercial del bien sería el de la opción, al margen del avalúo comercial o catastral que éste tuviera al momento de efectuar la enajenación. Así mismo, se expidió el decreto 2913 de 1991 con el fin de fijar pautas sobre la depreciación de los bienes entregados en leasing; el decreto 836 de 1991 en materia tributaria; la ley 6 $6^{\underline{a}}$ de 1992, luego reglamentada por el decreto 1250 de 1992, que suprimió el IVA para los cánones de arrendamiento en los contratos de leasing, y permitió descontar el impuesto sobre las ventas pagado del impuesto de renta en la adquisición de los bienes de capital entregados en leasing, para fortalecer y estimular los negocios de leasing en Colombia.

Hacia 1993 se produjo una profunda transformación en el sector, al permitir a las compañías de leasing captar ahorros provenientes del público, sin que esto significara una transformación en las operaciones mercantiles de leasing; entre tanto, se ordenó la conversión de las empresas de leasing en compañías de financiamiento comercial, escindiendo a dichos intermediarios financieros en dos grupos claramente diferenciados: las sociedades especializadas en leasing y las sociedades tradicionales de financiamiento comercial. Con el advenimiento de la ley 510 de 1999, sobre reforma al sistema financiero, y como consecuencia de la especialización de la banca, se genera una diferenciación del leasing respecto de las demás actividades de intermediación del sistema financiero, intensificando las operaciones relacionadas con este negocio.

Igualmente, cabe resaltar que en la década de los años 90 las compañías de leasing se convirtieron en compañías de financiamiento comercial y se amplían sus operaciones comerciales: redescuentos ante el IFI y BANCOLDEX, préstamos de las corporaciones financieras, captación mediante CDT's y emisión de bonos ordinarios. Además, se les autoriza realizar operaciones activas inherentes a las compañías de financiamiento comercial. En 2003 se concedió a Findeter re descontar contratos de leasing en ciertas condiciones comerciales. Luego, mediante los decretos 913 y 914 de 1993 se reglamentaron las características y 
otros aspectos relacionados con el contrato de leasing, con lo que se precisó y puntualizó la operación de leasing, aparte de que se fortalecieron las distintas especies de leasing ${ }^{12}$.

De todas maneras, conviene resaltar que todos los decretos aquí referidos han precisado las características y la naturaleza jurídica de la operación de leasing se reconoce que se trata de una actividad comercial; se sabe que en dicha operación no hay una intermediación de dinero sino de bienes; se contabiliza como una cuenta especial en el activo de la empresa y se reconoce como una operación mercantil de arrendamiento. Así mismo, es claro que las compañías de leasing son proveedoras de bienes y no de dinero, a diferencia de otras entidades del sector financiero (RAVASSA, 2000) ${ }^{13}$.

Conforme con lo anterior, para la ley, la doctrina (Cfr. BONIVENTO FERNÁNDEZ; ARRUBLA PAUCAR, PEÑA NOSSA) y la jurisprudencia nacional, el contrato de leasing es un negocio jurídico atípico, de carácter consensual, de ejecución sucesiva, bilateral y oneroso. Disiento, como se ha expresado hasta aquí, respecto del carácter consensual a que se refieren dichos conceptos, pues el leasing es un contrato prediseñado, pre-elaborado en formatos especiales por la compañía de leasing; el usuario, el consumidor, el empresario que requiere del servicio financiero del leasing, no se sienta con la compañía a elaborar y diseñar cada una de las cláusulas de este negocio jurídico, sino que, por el contrario, se ve obligado a aceptar las condiciones impuestas por la entidad de leasing. Este es un aspecto

12 "Se pueden distinguir fundamentalmente dos tipos de operaciones de leasing: el "Leasing Financiero" y el "Leasing Operativo". Las características básicas comunes a ambos tipos de contrato son las siguientes: los compromisos adquiridos tanto por el arrendatario como por el arrendador, no pueden ser prescindidos unilateralmente durante la vigencia del contrato. El contrato contempla expresamente a su fecha de término, una opción a favor del arrendatario para comprar el bien, renovar el contrato o devolver el bien" (VERGARA, 2014, p. 1).

13“El leasing financiero es una fuente de financiamiento que preserva la capacidad de endeudamiento de la empresa, permitiendo una disponibilidad aumentada del crédito, ya que la arrendataria puede obtener más dinero durante plazos más largos. En el arrendamiento financiero no se financia la totalidad del valor del activo, contribuyendo a la liquidez de la empresa arrendataria" (MAVILA, 2003, p. 88). 
que cabe discutir, que merece la pena tenerse en cuenta, porque en realidad no hay libre discusión (característica del contrato y, por ende, aspecto de la naturaleza jurídica), sino aceptación de condiciones por parte del empresario y usuario del leasing. Son condiciones generales de contratación y cláusulas predispuestas la que rigen este contrato. Ahora bien, en dichos conceptos jurídicos tampoco se hace referencia a uno de los elementos tan importantes como el relativo a los bienes objeto de leasing, pues por lo regular se ha dicho que se puede sobre bienes muebles e inmuebles, y nada respecto de los bienes inmateriales y los derechos. Punto que también es viable, sobre todo por tratarse de uno de los elementos del contrato, y por consiguiente, que concierne a su naturaleza jurídica. A mi juicio, desde el punto de vista de la naturaleza jurídica, se ha presentado un viraje, una transformación de la concepción clásica del leasing, y ahora se ha mutado a una concepción del contrato más proteccionista y garantista, donde el eje es el consumidor y el usuario, merced al hecho de que se ha reconocido que el contrato no es de libre discusión sino de adhesión. Y que, además, también desde el punto de vista de la naturaleza jurídica,

"Durante el año 2012, el mercado de Leasing en Colombia tuvo un crecimiento superior a $24 \%$ en el saldo de cartera productiva y colocaciones en activos que superan los $\$ 20$ billones de pesos. Una evolución que se logró gracias al ambiente favorable a la inversión tanto para empresas como para personas, a la entrada al mercado de algunos bancos que fortalecieron su propuesta de valor en esta línea de negocio y al desarrollo acelerado del leasing operativo. Unos resultados excepcionales en colocaciones, pese a que el crecimiento de la economía colombiana fue más leve que en 2011, lo que confirma el escenario esperado de aterrizaje suave de la actividad real; y aun cuando las condiciones regulatorias eran inestables" (BANCOLOMBIA, Escenario Colombia 2013). 


\section{EL LEASING EN LA JURISPRUDENCIA.}

A continuación se traen a colación las principales jurisprudencias sobre el leasing en Colombia, con base en el estudio elaborado por RICARDO MORENO BASTIDAS, intitulado: "Evolución histórica y jurisprudencial: alcance del contrato de leasing en Colombia", publicado por la Universidad San Buenaventura de Cali en 2011, pp. 47-48.

\section{Sentencia del 22 de Abril de 2002 - Sala de Casación Civil - Referencia: Expediente No. 6163 - Magistrado Ponente: Jorge Antonio Castillo Rugeles.}

"El problema de la sentencia se centra en una demanda de responsabilidad civil extracontractual invocada por los herederos de una persona que era titular del Derecho de dominio de un camión, el cual había sido entregado en leasing por una sociedad a otra, es decir, el bien estaba afectado por el contrato de leasing y al morir su titular los herederos pidieron la devolución inmediata del bien a la sociedad que lo tenía físicamente, al no hacerlo los herederos alegaban un perjuicio que se les había causado.

"El Tribunal decidió en la primera instancia no acataron las pretensiones de los demandantes por cuanto aseguran que no lograron probar los daños, es decir se centra en la materia probatoria sin embargo toca al contrato de leasing en varios momentos que son tomados por la Corte suprema en su Sentencia. A lo primero que se hace referencia es a que si el leasing es un contrato atípico, consensual, de adhesión, plurilateral, oneroso, conmutativo, de ejecución sucesiva, mercantil, orientado a financiar bienes productivos y cuya naturaleza jurídica se ha asimilado a la del contrato de arrendamiento, por cuanto que el usuario de este contrato obtiene el uso y disfrute del bien, por un periodo determinado, por un precio cierto y una opción de compra y siendo que se traslada contractualmente al usuario la obligación de mantener la cosa en estado de servir para el fin que ha sido arrendado. 
"Es decir define la naturaleza jurídica del contrato de leasing, pero se aparta de la tesis que se busca sostener hasta ahora y es que el contrato de leasing no es un contrato atípico. Por otro lado afirma también la Corte que por el mero hecho de haber entregado el automotor, refiriéndose al vehículo de la titular fallecida, para que otro lo usase y explotase, su dueña había desplazado la custodia y control (no la posesión) del mismo a un tercero. La persona que tiene el bien como locatario en realidad lo que ejerce sobre él es posesión, esa pareciere ser la tendencia de la Corte. A partir de lo anterior surge entonces uno de los problemas jurídicos del contrato de leasing, el interrogante que para la Corte es de sencilla solución, cuando muere el titular del bien que es parte del contrato de leasing, ¿sus herederos tienen derecho a reclamar el bien a la compañía que lo ha dado en leasing, o lo que se hereda es el beneficio del contrato?, es decir se debe diferenciar que en este caso el leasing operativo era un contrato entre dos sociedades, y el titular del bien era otra persona (causante), entonces lo que se debe hacer es ceder el contrato, por que en la ley no existen ningún tipo de cláusula especializada para el tratamiento de ese contrato con respecto a la sucesión, lo que si es claro es que existen unos Derechos adquiridos que se deben respetar y es lo que el fallador ha hecho en la sentencia.

"Lo que debieron hacer los herederos no era demandar a la compañía, así como se decidió vincular a la sociedad que en la actualidad tenía el bien y a la aseguradora por cuanto el asunto no se sustentó bien por parte de la defensa, sin embargo el fallo le fue satisfactorio y se soluciona un posible vacío legal sin ser el tema central del problema por medio de la jurisprudencia, que ya lo ha definido" (MORENO BASTIDAS, 2011, pp. 47-48).

Sentencia del 25 de Enero de 2008 - Sala de Casación Civil - Expediente: 2002-00373-01 - Magistrado Ponente: William Namén Vargas ${ }^{14}$.

${ }^{14}$ MORENO BASTIDAS, 2011, pp. 47-48. 
"Esta sentencia se incluye en esta evolución jurisprudencial aunque su discusión gira en torno más a un tema procesal, porque se evidencia un problema del contrato de leasing, o accesorio al mismo, en materia de seguros, que en principio puede parecer ajeno, pero resulta ser una consecuencia fundamental derivada del contrato. Es sobre un problema de una tracto-mula que había sido dada en leasing a un locatario, el locatario fallece, como en el contrato la muerte del locatario se puso como una causal para terminarlo y restituir el bien a la empresa, así mismo se insertó una cláusula contractual que indicaba la obligación de un seguro para daños del bien, así como un seguro para los cánones en caso de sufrir algún percance el locatario, según se entiende en la narración de los hechos. La cónyuge supérstite decide hacer efectivo el seguro y pagar todos los cánones que quedan faltando para poder hacer uso de la opción de compra e incluirla en la masa sucesoral, mientras eso la compañía pide la restitución del bien, pero ya habiendo recibido por parte del seguro los cánones que faltaban, entonces la Corte decide finalmente igual que el Tribunal a favor de la cónyuge.

"El problema que se presenta con motivo del contrato de leasing se refleja en la falta de orientación para diseñar el contrato y aunque hay normas que vigilan la operación de las compañías en este caso se hubiese cometido un abuso que tuvo que evitar la jurisprudencia que pudo haber sido resuelto por ley.

"La Corte Suprema dentro de sus providencias ha dedicado al contrato de leasing algunas líneas que ayudan a resolver asuntos con otras herramientas de Derecho y que dejan ver que hay conceptos variables de acuerdo a cada problema, a veces exponen el leasing como un contrato totalmente atípico y falto de alguna regulación, a veces parecieren indicar que no le hace falta, generalmente los problemas se desprenden de la mala elaboración del contrato por las cláusulas que se le insertan al mismo y que son a veces desequilibradas para las partes, pero la ley no prohíbe el uso de cierto tipo de cláusula si no en algunos casos por lo que en la interpretación como ya nos mostrará otra parte del recorrido 
jurisprudencial debe hacerse del contrato de leasing teniendo como sustento las normas comunes a los contratos después de no encontrar solución en el mismo".

\section{Sentencia del 14 de Junio de 2007 - Sala de Casación Civil - Expediente: 11001-3103-038-2001-00187-01 - Magistrado Ponente: Edgardo Villamil Portilla ${ }^{15}$.}

"Se toma esta jurisprudencia para proponer la poca importancia que tiene el proveedor para fines del contrato de leasing entre locatario y arrendador, como antes se expuso, muchos estudios del contrato de leasing toman al proveedor de los bienes que el arrendador entrega como un factor fundamental, pero desde el aspecto jurídico, lo que adquiere importancia contractual es la obligación pactada entre las partes que celebran el contrato, es decir si bien es cierto el proveedor tiene importancia relevante de seguro en el leasing como negocio, el contrato (donde se materializa el leasing) hace parte de otra esfera de obligaciones que no se pueden inmiscuir. Sin embargo la Corte y el Tribunal parecen no entender esto, y como en el contrato se pueden incluir cláusulas como estas, dónde la responsabilidad de la entrega y de la provisión se le entregue a otro, desligándose de nuevo la compañía de financiamiento por su responsabilidad, se beneficia el arrendador.

"En ese caso una compañía demanda a la leasing por cuanto esta no le entregó la totalidad de los bienes que le iba a entregar según el contrato, la otra alegó la falla del proveedor y por tanto intentó desprender su responsabilidad, más aún, el locatario dejó de pagar los cánones por cuanto el arrendador no cumplía sus obligaciones por lo que el segundo llenó el pagaré en blanco en el que habían soportado la deuda y demandó a éste.

\footnotetext{
${ }^{15}$ MORENO BASTIDAS, 2011, pp. 47-48.
} 
"Afirmó la Corte que de haber existido alguna deficiencia de calidad o cantidad de los equipos, ella era imputable a la clínica (la clínica era la compañía que sirvió como intermediaria en este caso como compañía de financiamiento) demandante que obró como mandataria de la sociedad financiera para recibir los bienes, y que del incumplimiento debía responder el proveedor, pues esa fue la voluntad de las partes.

"Aunque el problema pareciere complejo, es simple, pero la Corte deja entonces todo a la voluntad de las partes y es aquí en donde surge un interrogantes ¿La voluntad de las partes puede desequilibrar la relación jurídica del negocio?, Es decir, se puede decir entonces que siempre y cuando no constituya una cláusula ilegal dentro de un contrato que no ha dicho cuáles son sus cláusulas prohibidas más que las que el mismo Derecho civil propone, la compañía de financiamiento puede entonces aseverar que al brindar la posibilidad de adquirir un bien a un locatario, puede entonces determinar que en caso de existir un problema en la responsabilidad de la entrega completa de los bienes es entonces obligación del proveedor, que a veces puede ni si quiera ser parte de la esfera del conocimiento del locatario, y no de la compañía, pero el locatario al retrasarse en sus cánones que es también una obligación si se puede demandar incluso estando en incumplimiento de la obligación del proveedor.

"Lo anterior se explica mejor con esta determinación: el proveedor debe excluirse de la relación contractual de cualquier tipo de leasing como contrato, pues debe haber un contrato independiente externo que garantice al locatario que así como el cumple con sus obligaciones, no se puede recostar el arrendador en el proveedor y por tanto desasirse de su responsabilidad, que solo es extinta por el contrato mismo donde lo pactaron". 


\section{ANALISIS SOBRE LA NATURALEZA JURÍDICA DEL CONTRATO DE LEASING}

Mucho se ha discutido acerca de la naturaleza jurídica del contrato en mención. Tanto en la doctrina como en la jurisprudencia, así como la Superintendencia Financiera, han calificado el contrato como una especie de arrendamiento financiero con opción de compra, de carácter consensual, obviando la problemática de las cláusulas abusivas y, por ende, del carácter adhesivo de este negocio jurídico (Sobre cláusulas abusivas en la contratación, cfr. FARINA, 1999; RAVASSA, 2001).

En el contrato de arrendamiento común se concede el uso y el goce de un bien, como es obvio, sin la transferencia de dominio, a cambio del pago de un precio o canon periódico, que por lo regular es mensual. En el contrato de leasing, no sólo se concede el uso y goce de un bien (mueble, inmueble o de derechos), sino que, además, el usuario o locatario tiene la opción de compra para adquirir el bien, amortizando parte del precio con un porcentaje de los cánones que canceló durante la ejecución del contrato de leasing.

Ahora bien, el contrato de arrendamiento está regulado en los Códigos Civil y de Comercio; por el contrario, el contrato de leasing carece de regulación normativa en dichos ordenamientos, porque surgió después, a comienzos del siglo XX, y se fue regulando en forma paulatina mediante decretos especiales para el sector financiero y conceptos elaborados por la otrora Superintendencia Bancaria (hoy Superintendencia Financiera). De ahí, que la mayor parte de la doctrina y la jurisprudencia local pregonen que se trata de un contrato mercantil atípico.

Sea lo primero advertir, que si bien es cierto que existen elementos y características jurídicas que lo asemejan al contrato de arrendamiento, es menester reconocer que el contrato de leasing tiene autonomía y naturaleza propia, el leasing goza de completa independencia y se distingue fácilmente de 
otros contratos y negocios jurídicos; entonces, el primer error conceptual que realiza la doctrina local, es intentar encajarlo o encasillarlo en el contrato de arrendamiento; es decir, pretender presentarlo como una subespecie del contrato de arrendamiento civil o mercantil. Esta primera cuestión, obedece también al hecho de que se trata de un contrato anglosajón, propio de dicho sistema jurídico, ajeno a las categorías y conceptos del derecho continental europeo, del cual el sistema jurídico colombiano es heredero. Entonces, este primer escollo o encuadramiento jurídico, se debe indudablemente a la influencia del derecho romano-germánico en el derecho nacional, y al hecho de que es usual, es frecuente, casi que en forma subconsciente, encajar esta clase de negocios dentro de las categorías jurídicas del sistema jurídico del civil law (Respecto de los sistemas jurídicos, cfr. RENÉ DAVID y CAMILLE JAUFFRET-SPINOSI, Los grandes sistemas jurídicos contemporáneos, UNAM - Centro Mexicano de Derecho Uniforme. Facultad Libre de Derecho de Monterrey, México, 2010). Es un problema conceptual donde la doctrina ha empleado o utilizado las herramientas o los criterios del mismo derecho continental europeo, desconociendo la mutua interdependencia y las especificidades de los negocios y del derecho anglosajón. Aquí reside o estriba el primer valladar conceptual.

Sin embargo, con el desarrollo empresarial y contractual estadounidense y anglosajón difiere sensiblemente del derecho local, tiene categorías jurídicas distintas, un desarrollo y unas características especiales, que en definitiva, distinguen el derecho continental europeo del derecho anglosajón (Cfr. DAVID y JAUFFRET-SPINOSI, 2010). Así, por ejemplo, los contratos en el derecho anglosajón contienen un glosario de términos, destinado a precisar y definir algunos conceptos que, en principio, pueden ser ambiguos o ser interpretados en forma distinta por ambos contratantes y, por ende, generar controversias o litigios entre las partes contratantes, verbigracia, en el negocio jurídico del leasing (Cfr. KOZOLCHYK, 2010). El leasing es un trasplante jurídico del derecho norteamericano $\mathrm{y}$, por ello, cuando la doctrina y la jurisprudencia nacional pretenden encasillarlo o encuadrarlo dentro de la categoría o subtipo del 
arrendamiento, incurren en un error metodológico, pues el contrato de leasing tieneuna estructura jurídica, unas características y unos elementos propios, que permiten identificarlo e individualizarlo y, por ende, diferenciarlo de otros contratos, incluso del mismo contrato de arrendamiento, con el cual guarda proximidad.

Hoy, con la globalización de los mercados y la producción, existe una mutua interdependencia entre sistema jurídicos, y por ello no resulta extraño que el derecho local adopte categorías del derecho anglosajón, y a la inversa, que el tradicional derecho anglosajón aproveche y acoja categorías e instituciones del derecho continental europeo ${ }^{16}$. El contrato de leasing no es la excepción; con este negocio jurídico ocurre exactamente lo mismo: es un contrato anglosajón al que se le deben aplicar y se debe interpretar en el contexto jurídico y conforme al contexto en el que surgió, adaptándolo, como es lógico, a las necesidades y particularidades del derecho local.

En mi criterio, y aunque parezca una tautología, al contrato de leasing se le deben aplicar las categorías, los conceptos y los criterios del contrato de leasing, puesto que se trata de una figura jurídica autónoma, independiente del contrato de arrendamiento civil y mercantil, no obstante que guarden una estrecha relación o que existan algunos elementos que permitan asemejarlo o encuadrarlo en una subtipo de éste.

La otra cuestión que se plantea en el contrato de leasing en relación con su naturaleza jurídica, es la concerniente al carácter consensual del negocio de leasing. Ciertamente, al suscribir el contrato de leasing se considera que el contrato es consensual, porque las partes se ponen de acuerdo en la celebración del contrato y en las necesidades empresariales que mediante éste se pretende suplir; sin embargo, como es sabido, no hay libre discusión sino adhesión por parte del locatario y usuario del sistema financiero al clausulado prediseñado por

\footnotetext{
${ }^{16}$ En tal sentido, cfr. LÓPEZ GUZMÁN, 2007; REYES VILLAMIZAR, 2010; BONILLA MALDONADO, 2011.
} 
la compañía de leasing. El contrato es de adhesión y no de libre discusión; este es un aspecto que se da en la práctica; así es, y no hay duda de que la práctica empresarial y de negocios así lo imponga; la situación es que por intermedio de estos formatos pre impresos, contratos proforma, o contratos con cláusulas predispuestas, se presentan o se incluyen cláusulas abusivas e ilegales que van en contravía de los derechos del consumidor, del usuario y del empresario que acude a solicitar el servicio de leasing en el sector financiero. Las cláusulas no se redactan de común acuerdo entre las partes; las cláusulas no son discutidas y analizadas concienzudamente por cada una de las partes en el contrato de leasing, como tampoco pueden ser objetadas y eliminadas en forma unilateral o por solicitud del empresario locatario; el empresario locatario tiene únicamente dos alternativas, y tan sólo dos alternativas: o firma el contrato y acepta las condiciones en forma integral impuestas por la compañía de leasing, o no acepta las condiciones impuestas y decide no celebrar el contrato, ateniéndose a los efectos empresariales y de negocios que esta determinación conlleva. No celebrar el contrato por parte del potencial locatario es una alternativa, pero no es la solución para la empresa y el hombre de negocios, pues las compañías funcionan y desarrollan su actividad mercantil mediante el crédito. Por intermedio de éste la empresa crece y puede desarrollar en mejor forma sus actividades mercantiles; así que renunciar o no aceptar las condiciones impuestas por la compañía de leasing no resulta ser la mejor solución para la corporación y el empresario.

La solución al caso propuesto es aceptar las condiciones; sin embargo, la inclusión de este tipo de cláusulas, es decir, de cláusulas abiertamente abusivas y violatorias de la ley y la Constitución Política de 1991, se ha venido paliando mediante la normativa tuitiva del derecho del consumo; sí, en efecto, el Estatuto del Consumidor contiene disposiciones especiales para equilibrar el juego de fuerzas en este tipo de contratos. En dicha normativa se pretende equilibrar, paliar por así decirlo y, a su vez, mitigar la posición de dominio que ostenta la compañía de leasing dentro del contrato; igualmente, se estipula que las cláusulas ilegales y abusivas se dejan sin efectos, se anulan, se consideran en términos contractuales 
ineficaces. El derecho del consumo es proteccionista, su finalidad es la defensa del derecho a la igualdad en los contratos con cláusulas predispuestas. Es innegable, es indiscutible en la práctica, en la doctrina, en la ley, en el ámbito empresarial que el contrato de leasing es de adhesión; no se puede ocultar esta realidad viva del derecho de los negocios; sostener la tesis opuesta, la tesis de que el contrato es consensual es estar de espaldas a la realidad de los negocios, es negar un fenómeno, una situación jurídica cotidiana y plenamente aceptada en el ámbito mercantil.

Un tercer aspecto tiene que ver con el hecho de que el contrato de leasing es un contrato complejo, al que se le aplica la ley de los grandes números, y no un negocio jurídico aislado, como si estuviéramos en una economía parroquial y autárquica; es decir, capaz de abastecerse por sí misma, donde la contratación es un hecho ocasionaly separado. No, por el contrario, la contratación en el siglo XXI es masiva (Cfr. FARINA, 1999); LOPEZ GUZMÁN, 2007), es permanente, el pan de cada instante, de cada segundo en la economía moderna; por tanto, la contratación es múltiple, es continua y en masa, global, internacional.De ahí que el contrato de leasing no tiene una sola causa, como si en el ámbito del mercado y los negocios se celebrara como un acto civil aislado, sino que, por el contrario, se trata de un acto mercantil con múltiples causas, habida cuenta que se celebra entre varias partes y con muchísimos usuarios o empresarios interesados en adquirir maquinaria y nuevas tecnologías para mejorar la producción y los servicios en su compañía, o para muchos usuarios interesados en adquirir, por ejemplo, un inmueble para vivienda. Así las cosas, por ser un contrato con múltiples causas, complejo, es evidente que la ciencia jurídica no nos puede aportar más elementos para desentrañar lo concerniente a su naturaleza jurídica. Por consiguiente, es válido, analizarlo desde el punto de vista del análisis económico del derecho (Cfr. POSNER, 2000; SAMUELSON Y NORDHAUS, 1996; LEGUIZAMÓN ACOSTA, 2001). 
Conforme a estos lineamientos teóricos, y aplicando la ley de los grandes números, y con apoyo de la estadística y la teoría de probabilidades, se puede llegar a determinar en forma previa la conducta de un segmento de consumidores en el mercado. De hecho, mediante el análisis económico del derecho se puede predecir o establecer el posible volumen de negocios en materia de leasing, en una ciudad específica. Trasplantados estos conceptos al ámbito de las obligaciones y los contratos mercantiles se hace evidente, indiscutible que el contrato de leasing no es posible realizarlo en forma aislada (desde el punto de vista de la compañía de leasing), sino que siempre se realizará masivamente. En efecto, si la compañía de leasing tuviera tan sólo un empresario interesado en celebrar este negocio jurídico para mejorar su producción o hacer innovaciones tecnológicas en su empresa, el negocio no generaría ninguna rentabilidad para la compañía, ni tampoco podría financiar a más clientes, pues no tendría más recursos para hacerlo. La compañía realiza la financiación y con los pagos de otros clientes puede financiar a otros empresarios y adquirir otros bienes para concederlos en leasing (Cfr. ARRUBLA PAUCAR, 2009). Así, pues, es una operación mercantil que presenta varios negocios y contratos a la vez, facilitando a unos la adquisición de bienes para la empresa y recibiendo de otros nuevos bienes, así como captando recursos para aumentar o incrementar sus servicios en el mercado.

Más interesante resulta esta situación jurídica, desde el punto de vista de la utilidad y de la función económica del contrato de leasing, analizado todo ello en el marco de la naturaleza jurídica de éste. Porque, en efecto, mientras la compañía de leasing, como entidad del sector financiero, tiene la evidente intención de efectuar una financiación para obtener una utilidad mediante el pago de los cánones y, a su vez, servir de intermediario para la explotación de una maquinaria, de un inmueble o de nuevas tecnologías, la empresa que provee la maquinaria, los bienes o las nuevas tecnologías obtiene recursos y vende o explota dichos bienes, a cambio del pago de un dinero; y por otra parte, el locatario o los locatarios y usuarios del sistema de leasing, celebran otro contrato con la 
compañía para adquirir o para que se les conceda el uso y goce de dichos bienes y mejorar el funcionamiento de su empresa. Lo más interesante de esta compleja operación mercantil es que, mientras una de las partes quiere realizar un negocio jurídico, la otra quiere un negocio distinto dentro de la misma operación mercantil, y así se satisfacen los intereses comerciales y las expectativas empresariales de todos, lo que puede ocurrir porque en este contrato empresarial funciona la ley de los grandes números. Ahora bien, esto adquiere suma relevancia para la discusión jurídica concerniente a la naturaleza jurídica del contrato de leasing, ya que este análisis no está previsto ni contemplado en los principios de obligaciones y contratos y no se explica desde el escenario de la teoría de la causa en el derecho privado. Hay pluralidad de causas, lo cual implica una visión tridimensional o 
multidimensional del contrato mercantil de leasing, respecto a la tesis bidimensional tradicional del derecho privado. La estructura del contrato de leasing es, por consiguiente, distinta de la estructura del contrato de arrendamiento civil. En consecuencia, esta situación se presenta merced al hecho de que los contratos mercantiles se realizan en masa, y el leasing no es ajeno a este análisis.

Tan es así, que mientras por un lado la compañía de leasing celebra contrato de leasing back, por otro lado celebra contratos de leasing financiero y de leasing inmobiliario o de leasing internacional, y por otro lado, adquiere o recibe en consignación bienes, maquinaria e innovaciones tecnológicas para ser empleados y explotados por otros empresarios: los locatarios y usuarios del sistema de

Locatariousuario del

leasing
Empresa que provee los bienes y nuevas tecnologías
Compañía de leasing
Empresa que provee bienes y maquinaria

Locatariousuario del leasing 
leasing. Así las cosas, por ejemplo, no se podría aplicar la teoría tradicional del error esencial a que se refiere el artículo 1501 del Código Civil, pues de todas maneras analizada la operación mercantil en conjunto, el contrato es válido para todas las partes, al margen de la causa, del objeto y del precio en el contrato, que sí es diferente en cada una de sus partes. Por ello afirmo o sostengo que el contrato de leasing, desde el punto de vista de su naturaleza jurídica, es un negocio jurídico complejo donde subsisten múltiples causas; es decir, es tridimensional y multifuncional.

\section{CONCLUSIONES SOBRE LA NATURALEZA JURÍDICA DEL CONTRATO DE LEASING EN EL DERECHO COLOMBIANO}

1. De acuerdo con lo estudiado y analizado en esta investigación, el contrato de leasing es un contrato nominado y típico, pues la legislación, la doctrina y la jurisprudencia lo han desarrollado y decantado con amplitud y suficiencia, al margen de que no se haya legislado sobre éste en los Códigos Civil y de Comercio; aspecto que se comprende si se tiene en cuenta que este contrato surgió a comienzos del siglo XX en los Estados Unidos y fue trasplantado a Colombia como figura jurídica a fines de la década de los años 70, además de que se originó en un sistema jurídico anglosajón, que difiere del sistema jurídico del civil law nuestro. Igualmente, las partes, en virtud del postulado de la autonomía de la voluntad, pueden estipular libremente el contenido de sus cláusulas. En consecuencia, el contrato es ley para las partes, conforme a lo previsto por los artículos 1602 del Código Civil y $4^{\circ}$ del Código de Comercio.

2. El hecho de sostener que hoy día, merced a su amplia regulación (aunque dispersa), que es un contrato típico y nominado, no significa que deba ampliarse y detallarse en una próxima reforma al Código de Comercio la normativa sobre el leasing; no, por el contrario, ya la práctica empresarial y de los negocios, la jurisprudencia, la doctrina, los conceptos legales existentes, así como la costumbre mercantil han desarrollado la figura en 
forma clara y profunda, aparte de que los contratantes tienen libertad contractual para estipular lo que a bien tengan dentro del clausulado del negocio. Además, sobre los tipos de leasing ya existe una normativa especial, verbigracia, el leasing habitacional. Considero que lo más adecuado para una próxima reforma en materia mercantil es plasmar tan sólo algunos lineamientos del derecho contractual, delinear los principios del derecho contractual y de los negocios y, por supuesto, ampliar la autonomía de la voluntad entre las partes, a fin de que sean ellas las que dinamicen la contratación mercantil y, en particular, la contratación masiva sobre el leasing, y no el legislador, que siempre se queda corto.

3. El contrato de leasing no es un contrato de libre discusión sino de adhesión, merced al hecho de que es un negocio jurídico donde la parte dominante en el contrato establece las condiciones de contratación y las cláusulas son predispuestas, y algunas se pueden considerar abusivas, hasta el punto de que es menester ejercer un control de legalidad sobre las mismas, con el propósito de que el juez logre equilibrar el juego de fuerzas entre la compañía de leasing y los empresarios locatarios que acuden a este servicio financiero.

4. El contrato mercantil de leasing es un negocio jurídico complejo, en masa, con múltiples causas, empresarial, al que no se le pueden aplicar los lineamientos y criterios del derecho privado clásico, y que se comprende en mejor forma cuando se estudia desde la perspectiva de la ley de los grandes números.

5. La jurisprudencia nacional ha analizado con suma atención el contrato de leasing y ha logrado establecer que en él se incluyen cláusulas abusivas, al igual que ocurría con anterioridad en los contratos de seguros, donde se pone en condición de desequilibrio al consumidor, esto es, al potencial empresario locatario del sistema de leasing. Es diáfana la jurisprudencia nacional en sostener que ante esta situación, la cláusula temeraria o abusiva debe interpretarse en favor del locatario y usuario del contrato de leasing, siempre y cuando éste haya cumplido en forma satisfactoria sus 
obligaciones dentro del negocio jurídico de leasing (Cfr. MORENO BASTIDAS, 2011).

6. De otra parte, es importante resaltar la diferencia del leasing como figura operativa y de negocio del contrato de leasing, ya que existen diversidad de criterios por parte de la Superintendencia Financiera, así como de la jurisprudencia local; es claro que el leasing es el sistema empresarial, mientras que el contrato es el instrumento jurídico mediante el cual se logran satisfacer los intereses comerciales y de negocios de todas las partes involucradas en el negocio.

7. El contrato de leasing, desde el punto de vista de su naturaleza jurídica es de adhesión, de cooperación empresarial, de tracto sucesivo, mercantil, típico y complejo. El análisis o el estudio de su naturaleza jurídica implica, ineludiblemente, indisputablemente, el examen de sus elementos y características; es a ello, y a nada más que ello, a lo que se refiere el estudio sobre su naturaleza jurídica.

\section{BIBLIOGRAFÍA}

- AA.VV., (1999): Contratación internacional, Valencia, Editorial Tirant lo Blanch.

- AA.VV., (1997): Contratos internacionales, Madrid, Editorial Tecnos.

- ACquARONE, maría T., y EMBON, LEONAERDO G (2004): El leasing. Su instrumentación y encuadre en la actual financiación empresaria, Buenos Aires, Editorial Ábaco de Rodolfo Depalma. 
- ALMONACID SIERRA, JUAN-JORGE y GARCía LOZADA, NELSON GERARDO (1998): Derecho de la competencia, Bogotá, Legis Ediciones.

- alterini, atilio aníbal y lÓpez cabana, ROBERto m (2000): "Contratos atípicos", en AA.VV., Contratación contemporánea, Lima - Perú, Editorial Palestra - Editorial Temis.

- ÁlVAREZ-CORREA DUPERLY, EDUARDO (1991): Contratos bancarios, Bogotá, Universidad de los Andes.

- Álvarez londoño, lUIS fERNANdo y GALÁN BARRERA, Diego RICARDO (2002): Derecho internacional privado, Bogotá, Pontificia Universidad Javeriana.

- ANIF-FEDESARROLLO, "El leasing en Colombia: diagnóstico e impacto sobre la inversión y el crecimiento", disponible en: http://www.fedeleasing.org.co/Conceptos/leasing.pdf

- ARCHILA PEÑAlOSA, EMILIO JOSÉ: Posición de dominio y control de integraciones empresariales, en la Revista Ámbito Jurídico Legis, Bogotá, 28 de abril al 11 de mayo de 2003.

- ARESE, HÉCTOR FÉLIX (1999): "El contrato de leasing", en el libro Comercio y Marketing internacional, Buenos Aires, Grupo Editorial Norma.

- ARRUBLA PAUCAR, JAIME ALBERTO (2008): Contratos mercantiles, T II, Medellín, Editorial Diké. 
- ASOCIACIÓN DE BANCOS DEL PERÚ (2014): El leasing como aliado de la actividad productiva, en Asbanc Semanal, № 97, Año 4, viernes 7 de marzo de 2014.

- BANCOLOMBIA (2013): Leasing. Beneficios del arrendamiento operativo.

- BANCOLOMBIA. Leasing. Beneficios tributarios.

- BECK, ULRICH (1998): ¿Qué es la globalización?, Barcelona, Editorial Paidós.

- BERCOVITZ, ALBERTO (1992): La regulación contra la competencia desleal en la ley de 10 de enero de 1991, Cámara de Comercio e Industria de Madrid.

- BERMAN, HAROLD J (1997): La formación de la tradición jurídica de Occidente, México, Fondo de Cultura Económica.

- BOGGIANO, ANTONIO (1995): Contratos internacionales, Buenos Aires, Ediciones Depalma.

- BONILLA MALDONADO (2009): Teoría del derecho y trasplantes jurídicos, Bogotá, Universidad de los Andes - Siglo del Hombre Editores.

- BONIVENTO FERNÁNDEZ, JOSÉ ALEJANDRO (2000): Los principales contratos civiles y comerciales, T. II, Bogotá, Ediciones Librería del Profesional.

- BOtERo RESTREPO, CECILIA (2002): El derecho antitrust o de la libre competencia en los Estados Unidos, Medellín, Señal Editora. 
- BROSETA PONT, MANUEL (1991): Manual de derecho mercantil, Madrid, Editorial Tecnos.

- BURGOS BONILLA, JOSÉ ALEJANDRO y CABEZAS BARRANTES, CAROLINA (2012): El contrato de leasing, Facultad de Derecho, Universidad de Costa Rica.

- CADAVID GAVIRIA, LEÓN DARíO (2000): Derecho civil. Obligaciones, Bogotá, MacGraw-Hill.

- CALVI, NICOLÁS MARCELO: Análisis del contrato de leasing, Universidad Nacional de Córdoba, Argentina.

- CÁRDENAS QUIRÓS, CARLOS: El leasing o arrendamiento financiero, publicado en la Revista Peruana de Derecho de la Empresa, Contratación, Tomo IV, $\mathrm{N}^{\circ} 39$.

- CASTILLO TRIANA, RAFAEL (1994): Leasing: mecanismos financiero del futuro, Bogotá, Editorial Hojas e Ideas.

- Código Civil, Bogotá, Editorial Leyer, 2014.

- Código de Comercio, Bogotá, Editorial Leyer, 2014.

- COHNEN, SEBASTIÁN: El contrato de leasing: aspectos de su calificación jurídica, disponible en la Revista Jurídica de la Universidad Autónoma de Madrid, Año 2000, núm. 3, pp. 109-135. 
- COLPATRIA. MULTIBANCA. Modelo de contrato de leasing.

- Constitución Política de 1991, Bogotá, Editorial Leyer, 2014.

- COPPARONI, GUIDO LEONARDO (2008): Contrato de leasing: desarrollo de aspectos generales, Mendoza (Argentina), Facultad de Ciencias Económicas y Jurídicas Universidad del Aconcagua.

- Corte Constitucional. Sentencia C-936 de 2003. Expediente 4468. Magistrado Ponente: Eduardo Montealegre Lynnet.

- Corte Suprema de Justicia, Sala Civil. Sentencia de 22 de abril de 2002. Expediente № 6163. Magistrado Ponente: Jorge Antonio Castillo Rugeles.

- Corte Suprema de Justicia, Sala Civil. Sentencia de 13 de diciembre de 2002. Expediente 6462. Magistrado Ponente: Carlos Ignacio Jaramillo.

- Corte Suprema de Justicia, Sala Civil. Sentencia de 22 de octubre de 2001. Expediente 5817. Magistrado Ponente: Jorge Antonio Castillo Rugeles.

- Corte Suprema de Justicia, Sala Civil. Expediente 2002-00373-01. Magistrado Ponente: William Namén Vargas.

- Corte Suprema de Justicia, Sala Civil. Expediente 11001-3103-038-200100187-01. Magistrado Ponente: Edgardo Villamil Portilla.

- CORREA ARANGO, GABRIEL (2013): Comentarios al estatuto de arbitraje y amigable composición, Bogotá, Editorial Temis. 
- CUETO ESTRADA, JUAN PABLO (2009): Reflexiones jurídicas del contrato de leasing, en la Revista Advocatus, Edición especial № 13: 109 -122, 2009, Universidad Libre seccional Barranquilla.

- DALLA VIA, RICARDO (1999): Derecho económico constitucional, Buenos Aires, Editorial Abeledo-Perrot.

- DAVID, RENÉ y JAUFFRET-SPINOSI, CAMILLÉ (2010): Los grandes sistemas jurídicos contemporáneos, México, UNAM.

- DE SOLÁ CAÑIZARES, FELIPE (1963): Derecho comercial comparado, Barcelona, Editorial Montaner y Simon.

- Decreto 913 de 1993.

- DEPARTAMENTO DE ENTIDADES FINANCIERAS (2007): El leasing financiero: un mercado aun no explotado en Paraguay, diciembre de 2007.

- DURÁN BOHÓRQUEZ, EDWIN GIOVANNI (2004): El contrato de leasing financiero en Colombia, Bogotá, Pontificia Universidad Javeriana.

- Estatuto Orgánico del Sistema Financiero, Bogotá, Editorial Leyer, 2014.

- etCheVERRY, RAÚl ANÍBAL (1995): Derecho comercial y económico, Contratos, parte especial, tomo I, Buenos Aires, Editorial Astrea.

- FARINA, JUAN MANUEL (1999): Contratos comerciales, Buenos Aires, Editorial Astrea.

- FEDELEASING (2010): Manual jurídico del leasing, Bogotá. 
- FELDSTEIN DE CÁRDENAS, SARA (1995): Contratos internacionales, Buenos Aires, Editorial Abeledo-Perrot.

- FLORES DOÑA, MARÍA DE LA SIERRA: El leasing financiero internacional en el tratado de UNIDROIT.

- FLORES, SOLEDAD (2012): El leasing inmobiliario, en la Revista Científica de Ciencias Jurídicas y Notariales, Año 2, Vol. 2, pp. 155-170. La Rioja, Argentina.

- GACETA JURÍDICA. Modelo de contrato de leasing.

- GALGANO, FRANCESCO (1992): Negocio jurídico, Valencia, Editorial Tirant lo Blanch.

- GARCíA VEGA, ÓsCAR (2007): El leasing, en Autores Varios, Derecho comercial y societario, Bogotá, Ediciones Librería del Profesional.

- GHERSI, CARLOS ALBERTO (2006): Contratos comerciales, T. 2, Buenos Aires, Editorial Astrea.

- GIL ECHEVERRY, JORGE HERNÁN (2013): Régimen arbitral colombiano. Ley 1563 de 2012, Bogotá, Grupo Editorial Ibáñez.

- GuAl ACOSTA, JOSÉ MANUEL (2012): Cláusulas de exoneración y limitación de responsabilidad civil, Bogotá, Grupo Editorial Ibáñez. 
- GUTIÉRREZ APAZA, VERÓNICA ROSSY (2013): Leasing: un buen instrumento de desarrollo para las medianas y pequeñas empresas, Bolivia, Universidad Mayor de San Andrés.

- GUTIÉRREZ HERRERA, ANA LORENA (2003): El contrato de leasing: su desarrollo fiscal en Costa Rica, Universidad Latinoamericana de Ciencia y Tecnología ULACIT.

- HALPERIN, ISAAC (2009): Derecho civil unificado, Buenos Aires, Editorial Astrea.

- HERRERA, MERCADO, HERNANDO (2014): La impugnación de los laudos arbitrales. Análisis legal y jurisprudencial, Bogotá, Legis Ediciones.

- H. LEÓN TOVAR, SOYLA (1999): El arrendamiento financiero (Leasing) en el derecho mexicano. Una opción para el desarrollo, México, Universidad Nacional Autónoma de México.

- JINEsta LOBO, ERNESTO (1992): El contrato de leasing financiero (arrendamiento financiero) con opción de compra, en la Revista Judicial de Costa Rica, Año XVII, № 55, marzo 1992.

- LEASING TOTAL. Modelo de contrato de leasing o arrendamiento financiero.

- LEgUizAMÓN ACOSTA, WILLIAM (2000): Derecho constitucional económico, Bogotá, Ediciones Jurídicas Gustavo Ibáñez.

- LEguizamón ACOSTA, WILliAm (2001): Análisis económico del derecho, Bogotá, Ediciones Jurídicas Gustavo Ibáñez. 
- LEYVA SAAVEDRA, JOSÉ (2003): El leasing y su configuración jurídica, en la Revista Vniversitas de la Pontificia Universidad Javeriana, núm. 106, diciembre, 2003, pp. 743-789.

- LÓPEZ GUZMÁN, FABIÁN (2007): Introducción al derecho mercantil, Bogotá, Editorial Temis.

- LÓPEZ GUZMÁN, FABIÁN (2004): Preguntas y respuestas de derecho comercial general, Bogotá, Ediciones Doctrina y Ley.

- maRtínez CAMARgo, GINNA ALEJANDRA y DE LEÓN NOVOA MARTHA ALIDA (2013): Contrato de leasing y cláusulas abusivas. Estudio de su interrelación en el derecho colombiano, Bogotá, Universidad Militar Nueva Granada.

- MARTíNEZ CAÑELLAS, ANSELMO (2008): Aproximación al contrato de renting, en la Revista Electrónica de la Universidad de Granada, octubre 30 de 2008.

- MARTÍNEZ SÁNCHEZ, WILSON ALEJANDRO: El nuevo Código de Extinción de Dominio, en la Revista Ámbito Jurídico Legis, 2014, p. 3.

- MAVILA, DANIEL (2003): Leasing financiero, en la Revista Industrial Data, vol. (6) 1.

- Ministerio de Industria, Turismo y Comercio de España - Unión Europea Fondo Social Europeo (2014): Otras técnicas de financiación del comercio internacional. Leasing.

- MORALES ALZATE, JOHN JAIRO (2012): Derecho económico constitucional, Bogotá, Ediciones Doctrina y Ley. 
- MORALES CHAVARRÍA, SERGIO (2013): Leasing o arrendamiento financiero, disponible en: http://www.elfinancierocr.com/Centro-FinancieroLeasing-arrendamiento ELFFIL20130918 0002.pdf

- MORENO BASTIDAS, RICARDO (2011): Evolución histórica y jurisprudencial. Alcance del contrato de leasing en Colombia, Universidad San Buenaventura de Cali.

- NORTHCOTE SANDOVAL, CRISTHIAN (2010): Análisis sobre el contrato de leasing $\mathrm{o}$ arrendamiento financiero, en Actualidad Empresarial, $\mathrm{N}^{\circ} 199$, segunda quincena de Enero, 2010.

- OLARTE YEPES, CAROLINA (2005): El leasing habitacional: una opción al crédito hipotecario, Medellín, Universidad de Medellín.

- ORTEga NiÑO, ALEXANDRA MILENA y RUSO, JOHN (2011): La incursión del contrato de renting en Colombia y su desarrollo en ausencia de normativa propia, Bucaramanga, Universidad Industrial de Santander.

- ORTUZAR SOlAR, ANTONIO (1990): El contrato de leasing, Chile, Editorial Jurídica de Chile.

- OSPINA FERNÁNDEZ, GUILLERMO (2008): Régimen de obligaciones, Bogotá, Editorial Temis.

- PARRA RODRÍGUEZ, EDWIN JOHANN y QUINTANILLA ORTIZ, DIEGO ALEXANDER (2008): Efectos del tratamiento contable del leasing en la 
estructura financiera de las Pymes: tratamiento contable nacional e internacional, Facultad de Contaduría, Universidad Nacional de Colombia.

- PAZ RUSSI, CARLOS ALBERTO (2012): Análisis al proceso arbitral. Ley 1563 de 2012 y decreto 1818 de 1998, Cali, Universidad San Buenaventura de Cali.

- PEÑA NOSSA, LISANDRO (2014): Contratos mercantiles, Bogotá, Ediciones Ecoe.

- PINZÓN SANTOS, ANGELA MARÍA: Contrato de leasing y medidas cautelares en el proceso ejecutivo en Colombia, Bogotá, Universidad Libre.

- POSNER, RICHARD A (2000): Análisis económico del derecho, México, Fondo de Cultura Económica.

- RAVASSA mORENO, GERARDO JOSÉ (2000): Antecedentes del leasing en Colombia. Ponencia presentada para la Universidad Santo Tomás en el seminario sobre Derecho de los Negocios.

- RAVASSA MORENO, GERARDO JOSÉ (2001): Derecho comercial. Bienes mercantiles, T. I, Bogotá, Ediciones Jurídicas Gustavo Ibáñez.

- RAVAssa mORENO, GERARDO JOSÉ (2004): Derecho mercantil internacional, Bogotá, Ediciones Doctrina y Ley.

- RAVASSA MORENO, GERARDO JOSÉ (1990): Historia del comercio y del derecho mercantil, Bogotá, Universidad Santo Tomás.

- REVERTE NAVARRO, ANTONIO (1968): El contrato de leasing, Universidad de Murcia. 
- RODRíGUez AZUERO, SERGIO (2013): Contratos bancarios. Su significación en América Latina, Bogotá, Editorial Legis.

- ROSENBROCK LAMBOIS, JAVIER: Contrato de leasing, en Errelus, Compendio Jurídico, Tomo 62, p. 47, mayo de 2012.

- RUIZ JIMÉNEZ, KENDALL DAVID (2010): Leasing operativo y leasing financiero, Universidad Escuela Libre de Derecho.

- SAlAZAR, NATALIA; CABRERA, PILAR y BECERRA, ALEJANDRO (2011): El impacto del leasing financiero sobre la inversión y el empleo en las firmas colombianas.

- SAMUElson, PAUl A., y NORDhaUS, WILliam D (1996): Economía, Madrid, MacGraw-Hill.

- SANTOS BELANDRO, RUBÉN (2000): Arbitraje comercial internacional, México, Oxford UniversityPress.

- SELMAN NAHUM, ARTURO (2011): La cláusula penal en el contrato de leasing y su nulidad por falta de causa: una evolución en la jurisprudencia, en la Revista Chilena de Derecho, vol. 38, núm. 3, 2011, pp. 611-622. Pontificia Universidad Católica de Chile.

- SOTO, MOISÉS: Leasing. Publicado en monografías.com. Disponible en: http://www.monografias.com/trabajos12/eleasing/eleasing.shtml

- STIGLITZ, JOSEPH (2007): El malestar en la globalización, Barcelona, Editorial Taurus. 
- tamayo lOMBANA, AlBERTO (1990): Obligaciones, Bogotá, Editorial Temis.

- VALENCIA ZEA, ARTURO (1990): Derecho civil obligaciones, Bogotá, Editorial Temis.

- VALLEJO MEJÍA, JESÚS (1992): Obligaciones, Medellín, Editorial Diké.

- VERA MERINO, MARCELO: El contrato de leasing inmobiliario como instrumento de financiamiento para la empresa, disponible en: http://veramerino.com.ar/descargas/Publicacion6.pdf

- VERGARA, JULIO (2014): Leasing. Disponible en: http://api.ning.com/files/05pDTRvDyR8FXHZPzcySXe28ppFvf2QSH25FG8 nQZ5Uon-

T9OrUYviinoBIOILpLoKRFPmVmkW5sBzeCMNI2aSlaNn656E5j/Leasing.pd $\underline{f}$

- VICENT CHULIA, FRANCISCO (2001): Introducción al derecho mercantil, Valencia, Editorial Tirant lo Blanch.

- YANG POJAN (2002): Contrato de leasing, Departamento de Investigación, Universidad de Belgrano. 


\section{CAPÍTULO II}

\section{FUNDAMENTOS CONTRACTUALES DEL CONTRATO DE LEASING}

\section{PROBLEMA JURÍDico EN LO TOCANTE A LA NATURALEZA DEL CONTRATO DE LEASING}

En este acápite se pretende abordar el problema de la naturaleza jurídica del contrato de leasing desde la perspectiva jurídica de las características, los elementos y el abuso de posición dominante que detenta la compañía de leasing frente al consumidor $y$, por ende, frente al usuario del sistema financiero de leasing. Ciertamente, el problema esencial reside en que la doctrina mayoritaria en Colombia olvida o ignora un hecho empresarial tan complejo como es el relativo a los sujetos que participan en la operación y los efectos jurídicos que de allí se deriva. Por lo anterior, nuestra propuesta académica para resolver toda la 
problemática jurídica concerniente a su encuadramiento jurídico como negocio jurídico consensual, estriba en analizar y discutir sus elementos y características, haciendo análisis detallados, críticas y formulando alternativas diferentes, a fin de que en el ámbito jurídico y de los negocios este nuevo enfoque redunde en definitiva, en un mejoramiento y en un respeto o equilibrio de los derechos del usuario financiero frente a los derechos de las compañías multinacionales de leasing. El quid del asunto está centrado en el encuadramiento jurídico de la figura, y en como mutamos de concepto y encuadre jurídico sobre la naturaleza, a fin de proporcionarle soluciones prácticas al consumidor y usuario del sistema financiero de leasing, que es finalmente la parte débil en la relación contractual.

\section{RESUMEN}

En esta segunda parte de la investigación se abordan otros aspectos que no se mencionaron en la primera, y se complementan otros, en relación con la naturaleza jurídica del contrato de leasing, a saber: sus características, como sustancia de la naturaleza contractual y, por supuesto, sus elementos, para luego adentrarse un poco en el abuso de posición dominante en el contrato de leasing, en el clausulado abusivo $y$, por ende, en la forma de paliar esta clase de desequilibrios contractuales, con lo cual se demuestra, desde el punto de vista teórico y práctico que el contrato de leasing es de adhesión y no de libre discusión, eje central de la investigación y que motivó este esfuerzo desde el comienzo. Conforme con lo anterior, se examinan en detalle las características y los problemas que de allí se generan con el propósito de adoptar una postura académica al respecto. 


\begin{abstract}
In this secondpart of theinvestigationotheraspectsthatwerenotmentioned in thefirstaddressed, and complementeachother in relationtothe legal nature of thelease, namelyitscharacteristics, as thesubstance of the contractual nature and, of course, itscomponents, and thengo a littleway in the abuse of dominant position in the leasing contract, in theabusiveclauses and, therefore, onhowtoavoidthiskind of contractual imbalances, whichisshown, fromthetheoretical and practicalpoint of viewthattheleaseisformembership and no free discussion, thecore of

theinvestigation and thatmotivatedthiseffortfromthebeginning. In accordancewiththeabove, are discussed in detailthecharacteristics and problemsthat are generatedthere in ordertotakeanacademic position in thisrespect.
\end{abstract}

\title{
3. PALABRAS CLAVE
}

Naturaleza jurídica, elementos, características, abuso de posición dominante, cláusulas abusivas, contrato de adhesión, negocio jurídico de leasing.

\section{KEY WORDS}

Legal nature, elements, features, abuse of dominant position, unfairterms, contract of adhesion, legal business of leasing.

\section{METODOLOGÍA.}


El examen sobre la naturaleza jurídica del contrato de leasing se hace en forma escalar, es decir, se parte de sus características, para adentrarse luego en sus elementos, y llegar a determinar cómo es su naturaleza jurídica; esto es, cuáles son los fundamentos de ésta y cómo se diferencia este contrato de otros, qué lo distingue de otras figuras jurídicas. Igualmente, y ese es el objeto principal que se desarrolla enseguida, decantando, desde el punto de vista metodológico, el problema central, el eje seminal, como es el concerniente a que si el contrato de leasing es de libre discusión o si se trata de un contrato de adhesión, empresarial y complejo. Es una investigación cualitativa, exploratoria, comparativa con otras figuras, analítica y propositiva, con la que se pretende dilucidar y, por ende, derribar el paradigma doctrinal de que el contrato de leasing es un contrato de libre discusión, es decir, consensual, cuando en la realidad empresarial y de los negocios ocurre precisamente lo contrario.

\section{CARACTERÍSTICAS ${ }^{17}$}

\subsection{SE DICE QUE ES ATÍPICO}

En principio, la mayoría de la doctrina sostiene que el contrato de leasing es Atípico, pues no está regulado ni por el Código Civil ni por el Código de Comercio, y que con base en el postulado de la autonomía de la voluntad las partes establecen el alcance y el contenido del contrato, siempre y cuando no se contraríen el orden público y las buenas costumbres. La primera crítica que

\footnotetext{
${ }^{17}$ Los elementos del contrato de leasing constituyen la naturaleza jurídica de éste; jurídicamente, en estricto rigor, no hay y no existe otra manera de determinar y decantar la naturaleza jurídica de este contrato y de cualquier otro tipo contractual nacional e internacional. Dicha situación es ampliamente conocida por la doctrina y la jurisprudencia, es un paradigma, un axioma jurídico en el ámbito contractual que no admite controversia ni discusión. Por ello, desde el punto de vista metodológico, es el único camino para debatir y desarrollar la discusión concerniente a la naturaleza jurídica del leasing. No se trata de una postura puramente individual, autónoma, sino que, por el contrario, obedece a las categorías jurídicas diseñadas en el derecho de obligaciones y contratos.
} 
debemos hacer al respecto es que no es tan cierto que hoy día pueda sostenerse que el contrato de leasing es puramente atípico. ¿Por qué? La razón es muy sencilla, la atipicidad está referida al hecho de que este contrato no está expresamente regulado en la legislación mercantil ni en el Código Civil. Indiscutiblemente, el Código de Comercio no lo reguló, pero es obvio que no lo haya hecho, dado que en la época en que se expidió el actual Código de Comercio colombiano (1971), este tipo de contrato no estaba suficientemente desarrollado, no había evolucionado como para incluirse en la legislación comercial.

A ello se añade que nuestro estatuto mercantil es un fiel reflejo del Código de Derecho Privado Italiano de 1942; ese era el ordenamiento jurídico de avanzada de la época, y éste no regulaba por ninguna parte este tipo de contrato. Por supuesto, el Código Civil colombiano tampoco dijo nada sobre el particular, y era obvio, pues se trata de una legislación decimonónica, primigenia respecto de los negocios y operaciones mercantiles del siglo $X X$ y del $X X I$, inspirado en la contratación privada del derecho romano.

Sin embargo, leyes posteriores al Código de Comercio, verbigracia, los decretos 148 de 1979 y 913 de 1993 desarrollaron de alguna manera este tipo de contrato, amén de la doctrina de la Superintendencia Financiera (antes Bancaria) y de los usos y costumbres mercantiles. Así, pues, y haciendo una interpretación sistémica del estatuto mercantil, conforme a los artículos $1^{\circ}, 3^{\circ}, 4^{\circ}$ y $7^{\circ}$ del mismo, se puede afirmar sin ambages que el contrato de leasing ha dejado de ser un negocio mercantil puramente atípico para hacer el tránsito hacia un contrato regulado por la legislación mercantil. Y es que la legislación mercantil no sólo es el Código de Comercio como en forma absurda, miope y retardataria lo pretenden algunos, sino que, como es lógico, la legislación mercantil abarca todas las disposiciones que tengan que ver con los comerciantes, los empresarios y con las operaciones y actos mercantiles relacionados en los artículos 10, 20 y 25 del Código de Comercio colombiano. Ciertamente, no cabe duda que cuando la legislación 
financiera, la doctrina financiera y las normas reglamentarias se refieren al contrato de leasing, a las características de éste, a la estructura jurídico-funcional, lo que en realidad están haciendo es regulándolo, tipificándolo.

Ahora bien, lo que ocurre es que la mayoría de la doctrina asegura que el contrato es atípico porque no está regulado en el estatuto mercantil nacional; sin embargo, dicha postura es sumamente errónea ${ }^{18}$, por cuanto la legislación mercantil comprende un abanico mucho más amplio; de hecho, la legislación mercantil se contiene un abanico muy amplio y en constante expansión, verbigracia, el estatuto aduanero y la legislación sobre comercio exterior, la legislación financiera, la legislación tributaria comercial, los tratados comerciales internacionales, las leyes modelo en materia comercial (UNIDROIT, CNUDMI, CCI), entre otras (Cfr. LÓPEZ GUZMÁN, 2007).

En igual sentido se expresa FARINA, quien afirma lo siguiente: "En nuestra opinión el leasing es un contrato con naturaleza jurídica propia ${ }^{19}$ sin embargo,

\footnotetext{
${ }^{18}$ La tipicidad contractual se refiere al hecho de que un contrato esté encuadrado jurídicamente dentro de una categoría conceptual. Al hablar del tipo contractual se habla del nombre y desarrollo de la figura en la ley, en la jurisprudencia y en la doctrina, es lo que lo distingue jurídicamente de otros contratos, es su identidadjurídica; ello le proporciona vida propia respecto de otros contratos, y está íntimamente vinculado al concepto de naturaleza jurídica, pues al modificarse o transformarse sus elementos esenciales y sus características, se convierte en otro contrato mercantil, pierde su esencia y deja de ser leasing para convertirse, por ejemplo, en un contrato de arrendamiento civil o mercantil, o en un contrato de compraventa con pacto de retroventa. De ahí que el artículo 904 del Código de Comercio haya establecido la figura jurídica de la conversión del negocio jurídico, con las implicaciones que ello tiene para los contratantes y con el propósito de conservar el contrato o el negocio celebrado entre las partes (Principio de Favor Negotti).

${ }^{19}$ La doctrina, toda la doctrina jurídica tiene exactamente el mismo criterio de lo que es la naturaleza jurídica: elementos y características. Es un paradigma universal, ello tiene fundamento legal aquí en Colombia, e igualmente en el derecho comparado, e intentar establecer la diferencia entre lo que entiende un sector y otro de la doctrina por naturaleza jurídica es innecesario, ya que sería como discutir qué entienden unos autores por derechos fundamentales y otro sector de la doctrina. Es un concepto decantado, claro, preciso, que no admite discusión. De ahí que la crítica del profesor argentino FARINA al respecto es imprecisa, incompleta y descontextualizada, pues siempre que aludimos a la naturaleza jurídica del leasing, se debate sobre sus elementos y
} 
recurre nuevamente al autor italiano BUONOCUORE, quien enuncia diversas característicassobre la naturaleza jurídica: a) el leasing es un contrato típico, con una causa, un objeto y características peculiares, en el cual confluyen elementos propios de diversos esquemas jurídicos tradicionales, como son el mutuo, la locación y la venta; b) el leasing debe ser encuadrado dentro de la categoría de $<<$ negocio mixto >>, pues la intención económica perseguida por los contratantes está estrechamente vinculada con la estructura jurídica, característica de la locación de bienes productivos, pero presenta desviaciones respecto de este esquema, en razón de la finalidad económica de la operación, consistente en la actividad intermedia que desarrolla la entidad financiera entre el proveedor del bien y el tomador, pues el bien es adquirido por la sociedad de leasing, a los fines de la operación misma; (...)" (POJAN YANG, 2002, p. 7).

\subsection{BILATERAL}

La segunda característica es que se trata de un contrato bilateral. Ciertamente, la mayor parte de la doctrina (FARINA, PEÑA NOSSA, URÍA, CORRALES ROMEO y GARCÍA-BORBÓN, ARRUBLA, entre otros) coincide en sostener que se trata de un contrato bilateral en el que se generan obligaciones para ambas partes. Es discutible hoy día el sostener que se trata de un contrato exclusivamente bilateral. De hecho, la colaboración empresarial, la escisión de sociedades, la inversión extranjera y la globalización de la producción (fabricación por varias empresas en distintas zonas geográficas), entre otros aspectos, atenúan esta característica. La participación de varias empresas e inversionistas

características. Y el problema de fondo en este contrato es realmente el concerniente a si se trata de un contrato de adhesión o de libre discusión, así como al hecho de que se trata de un contrato mercantil complejo, al que se le aplican la ley de los grandes números, es decir, es multicausal y multifuncional, desde el ámbito empresarial. De otra parte, decir que tiene naturaleza propia, significa que no necesita tomar elementos y características de otros contratos comerciales, como, por ejemplo, el de arrendamiento, pues el leasing está tan desarrollado y estudiado y regulado, que es autónomo, se identifica y distingue fácilmente de otros tipos de contratos y no hay lugar a confusión con otros, así guarden algunos elementos o características similares. 
para la celebración del contrato de leasing es una situación común en el derecho privado contemporáneo, y por ello no es cierto, no es acertado, desde el punto de vista jurídico mantenerse en el criterio de la bilateralidad.

\subsection{CONSENSUAL O DE ADHESIÓN?}

Otra de las características que por lo regular se enuncian o atribuyen al contrato de leasing, es que se trata de un contrato consensual. Se dice que como es un contrato atípico, se perfecciona por el mero acuerdo de voluntades. Así mismo, se indica que, merced a su atipicidad, lo más práctico es elaborarlo por escrito y lo más detallado posible para que las partes no tengan dudas sobre el alcance, los efectos y las obligaciones de cada una. Igualmente, se sostiene que por tratarse de un contrato atípico, está sujeto a las estipulaciones de las partes (ARRUBLA PAUCAR, 2008; GARRONE y CASTRO SAMMARTINO, 1996; RODRÍGUEZ AZUERO; LAFONT PIANETTA). En otras palabras, el principio de la autonomía de la voluntad es determinante en la realización y celebración del negocio jurídico de leasing nacional e internacional ${ }^{20}$. Sin embargo, discrepo abierta y francamente de esta posición doctrinal, por cuanto en la actualidad no se puede sustentar esta tesis. ¿Por qué? Por las partes que participan en la celebración del contrato de leasing. Como es de público conocimiento, las partes que hacen este negocio no están en igualdad de condiciones, no son iguales desde el punto de vista jurídico y económico. Las empresas o compañías que ofrecen servicios de leasing son compañías autorizadas por el Estado (Superintendencia Financiera), y que, por ende, están en una situación privilegiada respecto del consumidor, del empresario que está interesado en celebrar un contrato de leasing.

\footnotetext{
${ }^{20}$ El contrato de leasing internacional está regulado por el Convenio de Unidroit. "El Tratado UNIDROIT se refiere al contrato de leasing financiero internacional, esto es, al celebrado entre una Sociedad de leasing y un empresario con establecimientos (principal o secundario) situados en el territorio de dos Estados contratantes y caracterizado porque la primera adquiere elementos integrantes del patrimonio empresarial a un fabricante, según las instrucciones recibidas por su cliente y a quien se le entregará para su uso a cambio del pago de cuotas periódicas, al margen de que se le reconozca o no un derecho de opción de compra al término del contrato" (FLORES OÑA, El leasing financiero internacional en el tratado de UNIDROIT).
} 
No es ajustado a la realidad, no corresponde a la realidad empresarial y de los negocios el sostener que una de las características del contrato de leasing es que son consensuales. No. $\mathrm{Y}$ en este punto quiero ser enfático, pues la consensualidad, como principio de la contratación mercantil, se desdibuja por completo si tenemos en cuenta la situación de privilegio, la posición dominante que una de las partes ostenta en el mercado. De ahí que es más sensato, más acorde con la dinámica de los negocios y operaciones mercantiles, afirmar que el contrato de leasing es de adhesión y no consensual. El empresario que se interesa en celebrar un contrato de leasing para modernizar su empresa y sus equipos, no puede discutir libremente las condiciones y el clausulado del contrato, sino que, por el contrario, debe someterse, ceñirse a lo que dice el contrato, a las condiciones prediseñadas por la entidad de leasing.

\subsection{ONEROSO}

Aparte de lo anterior, otra de los aspectos que indica la mayoría de la doctrina (RAVASSA MORENO, 2001; ARRUBLA PAUCAR, 2008; BONIVENTO FERNÁNDEZ, 2000), es el carácter oneroso del contrato de leasing. Se dice que son onerosos porque tanto la sociedad de leasing como la persona usuaria obtienen la utilidad, ya que cada una de las partes se obliga con el propósito de conseguir de la otra una contraprestación, que se considera equivalente a lo que una parte (el empresario) debe pagar. Sobre esta característica no hay duda ni reparos doctrinales; sin embargo, si lo que se pretende desarrollar es un proyecto social, un proyecto económico o un proyecto de supremo interés para la comunidad (interés general), el carácter oneroso no sólo se satisface con el pago que hace el empresario a la sociedad de leasing sino también a través de otros medios de pago (permuta, realización de una obra o labor, pago con acciones en un proyecto de inversión, entre otros). En actividades y empresas conjuntas para el desarrollo de proyectos se puede convenir con la sociedad de leasing que el pago se efectuará mediante el intercambio de bienes y servicios, con el pago de 
acciones, etc. Entonces, el pago no sólo se puede hacer en dinero, no es imperativo que así se haga, sino que, por el contrario, se pueden emplear otros medios de pago para hacerlo.

\subsection{DE TRACTO SUCESIVO}

Así mismo, la doctrina manifiesta que otra de las características del contrato de leasing es el denominado tracto sucesivo, debido a que las obligaciones se van cumpliendo en forma periódica. No obstante lo anterior, vale la pena preguntarse si esta característica se mantiene incólume en aquellos supuestos en que el contrato de leasing se celebra en el marco de un grupo de contratos, y el contrato principal es de ejecución instantánea. Pienso que en nada modifica o altera su condición o su carácter de tracto sucesivo, dado que al encontrarse vinculado o ligado a un grupo e contratos no modifica su esencia, su naturaleza jurídica, sus elementos jurídicos básicos; de lo contrario, degenera en un contrato sustancialmente distinto, y el hecho de estar conexo a un contrato o contratos principales de ejecución instantánea no muta el contrato ni el carácter sucesivo de las obligaciones que emanan de él. Pienso que la conexidad o interdependencia jurídica del leasing con otros contratos en el marco de una operación mercantil no puede perturbar la esencia del contrato, su estructura jurídico-funcional. Con razón, el artículo 1501 del Código Civil colombiano, preceptúa: "Se distinguen en cada contrato las cosas que son de su esencia, las que son de su naturaleza, y las puramente accidentales. Son de la esencia de un contrato aquellas cosas sin las cuales, o no produce efecto alguno, o degenera en otro contrato diferente; son de la naturaleza de un contrato las que no siendo esenciales en él, se entienden pertenecerle, sin necesidad de una cláusula especial; y son accidentales a un contrato aquéllas que ni esencial ni naturalmente le pertenecen, y que se le agregan por medio de cláusulas especiales".

De acuerdo a lo anterior, el hecho de que exista subordinación o vinculación directa del contrato de leasing con un grupo de contratos no puede ni debe 
considerarse como una modificación de las características y elementos esenciales del contrato de leasing. No. El contrato mantiene sus características, efectos y naturaleza sin que importe el hecho de que se realice en el marco de un grupo de contratos.

\subsection{MERCANTIL}

El carácter mercantil también es indiscutible, no obstante que participen empresas civiles en calidad de usuarios del leasing, o que se celebre dentro de un proyecto de interés común o de interés social. Esta situación o la condición de una de las partes tampoco altera su carácter mercantil, y además, porque el artículo 20 del Código de Comercio colombiano, así como otros ordenamientos jurídicos (España, Argentina, México, entre otros), consideran que este tipo de contrato es un acto objetivo de comercio, al igual que el giro u otorgamiento de títulos valores, aparte del hecho de que tan sólo se pueden ofrecer servicios de leasing por compañías debidamente autorizadas por la Superintendencia Financiera, es decir, por comerciantes (empresas nacionales y extranjeras), al margen de otras consideraciones referidas a la condición o no de comerciante (aspecto subjetivo). Amén de que en este tipo de contratos se ha propendido por la unificación conceptual, la armonización y unificación jurídica, sin distinguir entre personas civiles o mercantiles (Acerca de la unificación del derecho privado en obligaciones y contratos, cfr. HALPERIN, 2000).

\section{SUJETOS}

En el contrato de leasing usualmente se habla de dos partes. Ciertamente, encontramos: a) la compañía de leasing. Es la persona jurídica que está autorizada por la Superintendencia Financiera para desarrollar en forma profesional y estable la operación de leasing financiero. Es la titular del bien durante la vigencia del contrato (PEÑA NOSSA, 2012, p. 506); b) El cliente, usuario o locatario. Es la persona natural o jurídica que tiene la necesidad de 
adquirir un bien para usarlo durante un periodo de tiempo (PEÑA NOSSA, 2012, p. 506). Acerca del primer punto no hay debate jurídico, no hay discusión, a diferencia de otros contratos en el sector financiero, como, por ejemplo, la fiducia mercantil, que en el derecho inglés y norteamericano se admite que las personas naturales actúen en calidad de sociedad fiduciaria, contrario a lo que ocurre en el derecho colombiano ${ }^{21}$.

Empero, ni en el derecho comparado ni en el ordenamiento jurídico colombiano se admite o faculta a las personas naturales para actuar en calidad de sociedades de leasing; es requisito sine qua non para ofrecer esta clase de servicios el estar autorizado por la Superfinanciera, y para ello, como es sabido, se demanda el cumplimiento o satisfacción de unos requisitos objetivos (presupuesto, tipo de sociedad: anónima, respaldo financiero, transparencia, entre otros). Entre tanto, en lo que atañe al usuario o locatario, por lo general se dice que son empresas nacionales o comerciantes que necesitan de un bien o maquinaria. Sí, ello no amerita discusión.

Sin embargo, nada se dice en torno de entidades estatales, verbigracia, un Municipio, un Departamento, una entidad descentralizada, o un inversionista extranjero, o incluso un patrimonio autónomo. Este vacío doctrinal (BONIVENTO FERNÁNDEZ, 2000; RODRÍGUEZ AZUERO, 2002; ARRUBLA PAUCAR, 2008)no ha sido analizado por la doctrina. A juicio de quien esto escribe, los inversionistas extranjeros que estén autorizados para celebrar negocios en el territorio nacional pueden celebrar contratos de leasing sin restricciones de ninguna naturaleza; no

\footnotetext{
21 "En el leasing financiero intervienen tres sujetos: a) fabricante o proveedor; b) dador o intermediario financiero; y c) tomador o usuario. Se distingue esta modalidad porque es practicada por sociedades especializadas con vocación financiera: invierten su capital en activos fijos, y ceden su uso y goce a terceros para obtener un beneficio. El dador se limita a proveer el dinero y retener la titularidad de los bienes, pues el tomador busca el proveedor y el bien que le interesan, luego acude donde el primero indicándole las especificaciones para que efectúe la compra del equipo y el proveedor se lo entrega directamente al tomador" (JINESTA LOBO, 1992, p.
} 19). 
obstante, si el inversionista extranjero no está autorizado para realizar operaciones y negocios mercantiles en Colombia, no puede hacerlo; el problema estriba en la representación de estas compañías extranjeras, porque si el administrador actuó ultra vires, es decir, actuando más allá de las facultades contenidas en el poder o en las estatutos sociales, se presenta una extralimitación que puede dar lugar a una nulidad del contrato, salvo ratificación por la compañía matriz; y también se tendrá que examinar el hecho de que no obstante que no exista autorización expresa para celebrar contratos comerciales en Colombia, de todas maneras exista un tratado bilateral de inversión de carácter general, marco, por así decirlo, que permita entrever o interpretar que este tipo de operaciones y negocios mercantiles pueda ser celebrado por una compañía extranjera, ora en calidad de locatario, ora en calidad de sociedad o compañía de leasing, y se trata de un punto sobre el cual nada se ha dicho a nivel doctrinal o jurisprudencial.

Personalmente me inclino por la tesis restrictiva en lo que atañe a la posibilidad de actuar como sociedad de leasing, dado que el Estatuto Orgánico del Sistema Financiero es muy exigente y restrictivo sobre el particular; en lo concerniente a la posibilidad de actuar como locatario, merced a la prexistencia de un tratado marco de inversión, considero que nada obsta para que se pueda celebrar este contrato con una compañía nacional debidamente autorizada, y basta, a juicio, el tratado marco de inversión internacional, al margen de que la compañía extranjera no cuente con la autorización o permisos gubernamentales para realizar inversiones o negocios en el territorio nacional, y de todas maneras, este valladar se puede sortear por el inversionista extranjero mediante un leasing internacional que le permita traer los bienes o la maquinaria al territorio nacional. Además, la Constitución Política de 1991 en su artículo 100, el decreto 2080 de 2000 sobre la inversión extranjera en Colombia, le ofrecen un tratamiento jurídico igualitario a los inversionistas extranjeros y no prevén restricciones especiales al respecto. $\mathrm{Y}$, por último, en lo que atañe a los patrimonios autónomos, considero que también pueden celebrar contratos de leasing en calidad de locatarios o usuarios, sea para el mejoramiento empresarial, para la innovación tecnológica de los bienes que 
integran el patrimonio autónomo o para su gerencia y administración, verbigracia, un fideicomiso civil o comercial.

\section{REQUISITOS DE VALIDEZ DEL CONTRATO DE LEASING ${ }^{22}$}

Al contrato de leasing se le aplica el criterio general en materia de contratación privada, consistente en que para que un contrato sea válido, se requiere: capacidad, consentimiento, objeto y causa lícita. En tal sentido, el artículo 1502 el Código Civil colombiano, prescribe: "Para que una persona se obligue a otra por un acto o declaración de voluntad, es necesario: $1^{\circ}$ ) que sea lealmente capaz; $2^{\circ}$ ) que consienta en dicho acto o declaración y su consentimiento no adolezca de vicio; $3^{\circ}$ ) que recaiga sobre un objeto lícito; $4^{\circ}$ ) que tenga una causa lícita. La capacidad legal de una persona consiste en poderse obligar por sí misma, sin el ministerio o la autorización de otra".

\subsection{CAPACIDAD}

En lo que atañe a la capacidad, se deben aplicar los criterios generales establecidos por el Código Civil para toda clase de contratos. Las personas naturales pueden celebrar contratos de leasing, siempre y cuando sean legalmente capaces y su consentimiento no adolezca de vicios (error, fuerza y dolo). Por tanto, la persona que celebra un contrato de leasing no puede ser un discapacitado, en los términos a que se refiere la ley 1306 de 2009. Igualmente, tiene que ser un mayor de edad; de lo contrario, tendrá que contratar por intermedio de apoderado. Si éste no cuenta con el poder para celebrar el contrato 0 el poder es insuficiente, el contrato puede ser declarado nulo. El profesor BONIVENTO FERNÁNDEZ (2000, p. 370) es de la opinión contraria, ya que considera que la falta de autorización o poder para celebrar el contrato de leasing

\footnotetext{
${ }^{22}$ Los requisitos de validez del contrato de leasing también resultan fundamentales a la hora de discutir sobre la naturaleza jurídica del contrato; complementan sus aspectos esenciales: elementos y características y permiten discutir igualmente sobre diversos criterios en el ámbito contractual.
} 
no genera nulidad en el contrato. A juicio de este autor, no se estaría frente a un contrato de leasing sino a una modalidad distinta, que se rige por los principios de contratación que más se aproximen a dicho negocio jurídico. Disiento por completo de esta tesis; el hecho de que no exista autorización o poder para celebrar el contrato de leasing no modifica, no transforma o muta el sentido, alcance, naturaleza y estructura del contrato, eso no es fiel a la realidad jurídica del contrato de leasing. El hecho de que una de las partes, concretamente el supuesto apoderado o mandantario del empresario locatario o usuario del leasing, no tenga el poder para actuar o no tenga la autorización para hacerlo en nada afecta el contrato en sí mismo, porque la sociedad de leasing o no celebra el contrato, o si lo celebra, el contrato puede ser declarado nulo por falta de capacidad, conforme a lo estatuido por el artículo 1502 del Código Civil colombiano, en armonía con lo dispuesto por el artículo 899 del Código de Comercio que, en forma expresa, estipula que un negocio jurídico es absolutamente nulo cuando se haya celebrado por persona absolutamente incapaz (Véase CADAVID GAVIRIA, 2000; VALENCIA ZEA, 1990; TAMAYO LOMBANA, 1990; VALLEJO MEJIA, 1992; ARRUBLA PAUCAR, 1994, T. I, p. 174).

Además, el contrato de leasing es un contrato de adhesión más que un contrato de libre discusión; por consiguiente, está prediseñado en formatos o formularios elaborados previamente por la sociedad leasing. Esa es la realidad del mundo del comercio y los negocios, nadie, ningún empresario, comerciante o gerente se sienta con una compañía de leasing a diseñar cláusula por cláusula, a redactar cada una de las estipulaciones del contrato de común acuerdo con ésta; por el contrario, lo único que hace el empresario, comerciante o gerente es recibir el formato, leerlo y aceptarlo o no, pero la tan cacareada autonomía de la voluntad se desdibuja por completo aquí, pues no hay consensualidad sino aceptación de un contrato previamente elaborado por la entidad correspondiente que, en últimas, es la parte dominante en el contrato. 
Aquí el autor anteriormente enunciado confunde la conversión del negocio jurídico con la nulidad absoluta; y como es sabido, se trata de conceptos completamente diferentes. Vale la pena recordar que el artículo 904 del Código de Comercio, señala: "El contrato nulo podrá producir los efectos de un contrato diferente, del cual contenga los requisitos esenciales y formales, si considerado el fin perseguido por las partes, deba suponerse que éstas, de haber conocido la nulidad, habrían querido celebrar el otro contrato".

Esta situación es claramente descrita por el profesor FRANCESCO GALGANO (1992, pp. 323 - 324), al referirse al Código de Derecho Privado Italiano, fuente legal directa en la que se inspiró el legislador colombiano para redactar nuestro Código de Comercio, en los términos que se exponen enseguida:

El contrato nulo, en cambio, es susceptible de conversión. Lo cual sucede cuando un contrato, nulo como contrato de un tipo determinado, presenta sin embargo los requisitos de otro tipo contractual: cuando, teniendo en cuenta el fin perseguido por las partes, pueda entenderse que estas también habrían querido el distinto tipo contractual el cual están presentes sus requisitos de forma y de sustancia, el contrato nulo producirá los efectos de este tipo contractual. (...) La conversión del contrato nulo es aplicación de un principio general, el principio de la conservación del contrato: la ley, mientras sea posible, tiende a atribuir efectos a una declaración de voluntad; apoya la conclusión de negocios, en vez de su falta de celebración, la circulación de la riqueza, antes que su inmovilización. La conversión implica un cambio en la causa del contrato: el artículo 1424 del Código de Derecho Privado Italiano lo hace posible dentro de un ámbito circunscrito $\mathrm{al}<<$ fin perseguido por las partes $>>$. Si este fin es perseguible igualmente mediante distintos tipos contractuales, y el tipo elegido por las partes presenta los requisitos de forma o de sustancia prescritos, el contrato queda convertido en el tipo contractual del que presente los requisitos establecidos. El artículo 1424 se expresa con un 
lenguaje ambiguo, justificado por la preocupación de contemporizar el principio de conservación con el respeto a la voluntad de las partes: el cual subordina la conversión a la presencia de la llamada $<<<$ voluntad hipotética > de los contratantes, los cuales habrían querido el otro contrato si hubiesen conocido la nulidad del que concluyeron.

Según lo anterior, si las partes tienen un fin distinto, no obstante la presencia de la nulidad, el contrato pervive y se ejecuta pero transformado, esto es, convertido en un negocio jurídico diferente. La explicación que ofrece el profesor GALGANO se ajusta por entero al derecho privado colombiano, no se aparta del criterio a que alude el artículo 904 del Código de Comercio colombiano. Y es obvio, pues la doctrina y la legislación italiana son fuente directa del Código de Comercio colombiano. Ahora bien, en torno de la discusión jurídica que aquí se viene desarrollando, es diáfano e inobjetable que la falta de capacidad hace que el contrato de leasing pueda ser declarado nulo, conforme a lo previsto por el artículo 899 del estatuto mercantil, y no puede sostenerse que al no poder celebrarse éste, las partes pueden celebrar uno similar, pues por razones obvias ello es ilógico, ya que si una empresa acude a una sociedad de leasing para conseguir unos bienes o una maquinaria, la falta de poder o autorización para actuar no le permite a las partes celebrar el contrato, pero no hay forma, ni lógica jurídica en afirmar que el contrato se puede convertir, con base en lo dispuesto por el artículo 904 del Código de Comercio colombiano, en aras de conservar el negocio jurídico, independientemente de cuál sea el contrato en que se haya convertido.

Sencillamente, la falta de capacidad genera nulidad; situación diferente es que a partir del hecho de que existan elementos contractuales similares, próximos, derive en un contrato de arrendamiento comercial y las partes quieran celebrarlo, quieran mantener la relación comercial y de negocios con este tipo contractual, pero se trata de una hipótesis referida a los elementos esenciales del contrato (C. C., art. 1501) y no a la falta de capacidad. En consecuencia, la tesis del profesor BONIVENTO FERNÁNDEZ (2000, p. 370) está orientada a resolver un problema 
jurídico sustancialmente distinto, es equivocada y no se ajusta a la realidad del comercio y los negocios en el siglo XXI.

\subsection{CONSENTIMIENTO}

En lo que respecta al consentimiento, conviene señalar que debe estar libre de vicios: error, fuerza y dolo. Sobre el particular la doctrina ha decantado amplia y suficientemente cada uno de ellos. Sin embargo, hay un aspecto sobre el cual no se han dedicado estudios, ponencias o investigaciones; me refiero en concreto a la lesión como vicio del consentimiento. Este punto tiene suma importancia en el ámbito del leasing inmobiliario. La inexperiencia, la situación de ignorancia, el estado de necesidad, son causales de la lesión, y ésta, es causal de nulidad en algunos ordenamientos jurídicos. A diferencia del ordenamiento jurídico colombiano, donde la lesión tan sólo está referida a la desproporción económica, en el derecho privado comparado la figura ha evolucionado y se considera vicio del consentimiento. De hecho, vale la pena agregar que en Colombia hubo un proyecto de ley en este sentido; me refiero al reputado Proyecto de Código de Derecho Privado del profesor ARTURO VALENCIA ZEA. EI maestro VALENCIA diseñó un proyecto destinado a unificar el régimen civil y comercial en un solo Código, a semejanza del Código Suizo de las Obligaciones y del Código de Derecho Privado Italiano de 1942. Ciertamente, en el artículo 88 del mencionado proyecto, se establecía: "Si una persona ha sido determinada por estado de necesidad, explotación de su ignorancia o de su inexperiencia a celebrar un negocio jurídico que le causa un perjuicio manifiestamente anormal, puede, dentro del año siguiente, pedir la nulidad del negocio".

Este criterio, novedoso para nuestro sistema jurídico, pero reconocido en otras legislaciones, es aplicable a cualquier clase o tipo de contrato. Así las cosas, si se introdujera dicha figura en el ordenamiento nacional, se podría presentar la lesión en el contrato de leasing como vicio del consentimiento. $Y$ no se debe confundir con la figura jurídica de la lesión enorme, referida a un desequilibrio económico 
contractual. Pienso que nuestra legislación está en la obligación de avanzar en este sentido y, por ende, dar cabida a la lesión como vicio del consentimiento. Por contera, sería asimismo aplicable al régimen jurídico del contrato de leasing.

Acerca de la lesión como vicio del consentimiento, explican VALENCIA ZEA y ORTIZ MONSALVE (1994, T. I, pp. 426 - 430):

Desde los romanos se consideró la usura en los negocios como inmoral, como lesiva de la voluntad y de las buenas costumbres. En los modernos sistemas jurídicos, este principio fundamental ha tomado dos orientaciones principales: una, la que le dieron los mismos romanos, consistente en hacer aplicaciones concretas mediante la laesioenormis; la otra representada por ciertas leyes alemanas anteriores a 1900, y que fueron recogidas en el artículo 138 del Código Civil alemán. Tanto en el Código de Napoleón como el de Bello, solo conocen el primitivo sistema de la lesión enorme.

En general, cuando un negociante, en virtud de ciertas circunstancias, sobre todo por encontrarse en una situación apurada o de necesidad, o por el escaso desarrollo de sus facultades mentales, o por su inexperiencia en el comercio, realiza un negocio que manifiestamente es perjudicial a sus intereses, en verdad no ha expresado libremente su voluntad, es decir, que esta ha sido viciada.

El Código Civil materializó esa idea exigiendo un criterio numérico, esto es, una relación entre el valor del objeto del negocio y lo que se recibe o se da por él, por una parte; y, por otra, circunscribió tal concepto a un número limitado de negocios: compraventa de inmuebles, permuta de inmuebles, mutuo con intereses, cláusula penal, aceptación de una herencia, partición de bienes, dación en pago, en la hipoteca, en el censo (...). Prácticamente son estos los últimos casos en que el Código Civil obedecen al concepto de lesión. 
Mediante una ley de 1880 se estableció en Alemania a lesión a la concesión del mutuo o a las prórrogas de créditos pecuniarios. Esta noción e usura evolucionó con una ley de 1893 que alió el concepto de la lesión a otros negocios. Los juristas alemanes comprendieron que no solo mediante un capital en dinero puede explotarse el estado de necesidad, ligereza o de inexperiencia de otra persona, sino también mediante cualquiera otra prestación (arrendamiento, sociedad, renta vitalicia, etc.); de ahí que dicha ley establezca que es contraria a las buenas costumbres la usura con que en cualquier negocio jurídico se explote el estado de necesidad, la ligereza o la inexperiencia de otra persona.

El artículo 138 del Código Civil de 1900 hace una síntesis de las leyes enunciadas, y en el párrafo $1^{\circ}$ anula el negocio lesivo de las buenas costumbres, en tanto que en el párrafo $2^{\circ}$ dice textualmente: "Especialmente es nulo aquel negocio jurídico mediante el cual una persona, aprovechando la situación de necesidad, las limitadas facultades mentales o la inexperiencia de la otra, hace que esta prometa o conceda a la primera o a un tercero, a cambio de determinada prestación, ventajas patrimoniales que excedan de tal manera el valor de esa prestación que, en relación con las circunstancias, estén en enorme desproporción con ella".

El concepto de la lesión en los negocios, conforme a este texto legal, debe medirse teniendo en cuenta varios puntos de vista: $\left.1^{\frac{a}{}}\right)$ Una persona puede encontrarse en tres situaciones distintas para realizar un negocio lesivo a sus intereses: estado de necesidad, como cuando el vendedor se ve compelido a vender por cualquier precio, o un trabajador a emplearse por cualquier salario; debilidad de sus facultades mentales y estado de inexperiencia en el comercio. En cualquiera de estos estados la voluntad carece de la suficiente libertad, es decir, se encuentra viciada. Pero el artículo 138 no limita a tales cosas la aplicación de la lesión, sino que simplemente los considera como principales. Con razón advierte 
ENNECCERUS que existe lesión en los demás casos en que, <<según la opinión general de los hombres que piensan con espíritu de equidad y justicia>>, media la explotación usuraria, como cuando alguien se aprovecha inmoderadamente de su prepotencia económica, o de la posición de monopolio o de mayoría que se tiene en una sociedad, para perseguir intereses reprobables por las buenas costumbres; 2aㅡ La lesión puede presentarse tanto en los contratos de enajenación (compraventa, permuta, aporte a una sociedad, etc.) como en los de administración (arrendamiento, trabajo, etc.); no es necesario distinguir si se trata de negocios que recaen en muebles o inmuebles. En síntesis, todo negocio oneroso es aquel que tiene $<<$ por objeto la utilidad de ambos contratantes, gravándose cada uno en beneficio del otro>>. 3ํ) La usura o lesión puede presentarse no solo en la conclusión de los negocios, sino también en los negocios de cumplimiento; la explotación usuraria puede realizarse en favor del otro negociante o de un tercero.

Estos derroteros se aplican igualmente en los ordenamientos jurídicos de Suiza, Francia, Portugal, Bolivia, México, Polonia e Italia. Sin embargo, en contra se podrá argüir que mediante el abuso de posición dominante, las cláusulas abusivas, el equilibrio económico de los contratos, entre otros, se podrán equilibrar los negocios jurídicos entre la compañía de leasing y el locatario o usuario del leasing. Para nadie es un secreto que la compañía de leasing se encuentra en una situación privilegiada, en una posición dominante respecto de la empresa que requiere los servicios de leasing. Desde una panorámica general se puede pensar que no es menester incluir en la legislación colombiana la lesión como vicio del consentimiento, máxime por cuanto existen otros medios legales y constitucionales que, en últimas, conducen al mismo fin; sin embargo, considero que nada obsta para que se pueda aprovechar la experiencia del derecho comparado y para que se puedan madurar estas ideas al respecto, pues no resulta descabellado ni inconveniente para la práctica comercial y de los negocios de leasing, entre otros, el introducir esta figura en el ordenamiento jurídico 
nacional. De hecho, la posición de dominio que ejercen las compañías de leasing respecto del usuario o locatario es un problema jurídico digno de analizarse y menguarse mediante diversas opciones legales. Quien dirige una empresa puede ser inexperto; las pequeñas y medianas empresas que comienzan a desarrollar sus actividades en el mercado no gozan de la misma experiencia de una compañía multinacional; en este orden de razonamientos, no es ilógico pensar que un empresario nuevo, sin mayor conocimiento en el área específica donde explota su actividad mercantil, pueda encontrarse en un estado de necesidad, merced a una crisis económica o por inexperiencia en el sector. Entonces, el primer argumento principal que se emplea en el ámbito del derecho comparado para fundamentar la figura de la lesión como vicio del consentimiento, tiene cabida en el contexto empresarial y de los negocios, y en particular, en la dinámica de los contratos de leasing. En resumen, es válido que en negocios de administración como el leasing tenga cabida la figura jurídica de la lesión, de luenga tradición en el derecho privado comparado.

La solución, a mi juicio, es modernizar la legislación civil y comercial al respecto. Sin embargo, basta con una simple reforma al artículo 1502 del Código Civil colombiano. Pero, como es sabido, los proyectos de modernización e internacionalización del derecho privado en Colombia no han fructificado, so pretexto de atender con suma urgencia conflictos sociales y económicos de carácter nacional. Y más allá de los dilemas jurídicos que se puedan plantear en este terreno, en verdad urge una reforma a la legislación civil, en la que, como aquí se explica, se incluya la lesión como vicio del consentimiento, con el propósito de que los empresarios, los comerciantes y el consumidor puedan contar con otro instrumento jurídico para equilibrar el juego de fuerzas en el mercado $y$, por ende, el abuso de la posición dominante que ejercen las compañías de leasing en el mercado colombiano.

Por ello, se ha venido sosteniendo hasta aquí que es un contrato de adhesión y no consensual. El carácter de adhesión amerita, indudablemente, la inclusión de la 
figura de la lesión como vicio del consentimiento, en aras de que el principio de equilibrio contractual sea una realidad. Tan es así, que en el derecho comparado se reconoce esta situación. SOYLA H. LEÓN TOVAR (1989, p. 44) explica que el contrato de leasing es de adhesión, en los términos que se transcriben a continuación:

Es así porque sus cláusulas son redactadas unilateralmente por la arrendadora financiera, sin que el arrendatario financiero, para aceptar el contrato, pueda discutir su contenido; de suerte que la Ley General de Organizaciones y Actividades de Crédito (art. 76) establece la previa aprobación por parte de la Comisión Nacional Bancaria y de Seguros de las solicitudes y contratos, tanto respecto de su contenido, como de los requisitos tipográficos, para considerar fácilmente legibles los caracteres empleados. En este punto valdría la pena cuestionar si es o no aplicable, y en qué medida, lo dispuesto en el artículo 64 de la Ley Federal de Protección al Consumidor, en cuanto al concepto de <<contrato de adhesión>>, y en cuanto a que éstos deben ser escritos íntegramente en idioma español; y por último, qué debemos entender por <<íntegramente>>, porque tal vez éste podría ser un argumento más a favor de quienes se resisten a llamar leasing al contrato.

\section{EL OBJETO EN EL CONTRATO DE LEASING ${ }^{23}$}

La declaración de voluntad en el contrato de leasing tiene por objeto el dar, pero esa obligación de dar tan sólo se puede referir a conceder el uso y goce de la cosa; sin embargo, si el empresario o usuario del leasing ejerce la opción de compra, el dar implica una verdadera transferencia de dominio en los términos previstos por el artículo 905 del Código de Comercio colombiano. Como bien afirma SOYLA H. LEÓN TOVAR (1989, p. 50), "El objeto del contrato es otro de los elementos de su existencia, y está constituido por la cosa que el obligado debe

\footnotetext{
23 "El contrato de leasing tiene por objeto conceder un financiamiento a una persona con la
} finalidad de que ésta pueda adquirir un determinado bien" (NORTHCOTE SANDOVAL, 2010, p. 1). 
dar y el hecho que el obligado debe hacer; consiste en una prestación cuyo contenido es dar bienes o prestar servicios destinados al cumplimiento del fin del contrato. El objeto se clasifica en directo o indirecto. El primero consiste en la conducta de los contratantes que se manifiesta como una prestación de hacer, que consiste en entregar un bien del cual se ha de conceder su uso o goce; mientras que el segundo, el objeto indirecto, es la cosa misma, los bienes que la arrendadora financiera ha de adquirir y entregar en arrendamiento financiero al arrendatario financiero; es decir, se presentan dos situaciones, la prestación de un hecho y la prestación de una cosa".

Los bienes que se conceden en leasing son bienes muebles, por lo general, productivos, maquinaria, equipos de alta tecnología, vehículos de transporte para la renovación de la empresa, que están adosados para los correspondientes efectos jurídicos de la licitud en el objeto, existencia y determinación, conforme a las normas que regulan el contrato de leasing (En el mismo sentido ACQUARONE y EMBON, 2004; BONIVENTO FERNÁNDEZ, 2000; CASTILLO TRIANA, 1994).

Ahora bien, como bien lo indica el artículo 1521 del Código Civil colombiano, hay objeto ilícito en la enajenación de las cosas que no están en el comercio, de los derechos o privilegios que no pueden transferirse a otra persona, de las cosas embargadas por decreto judicial (Véase OSPINA FERNÁNDEZ, 2008; TAMAYO LOMBANA, 1990). En este contexto, si hay objeto ilícito en el bien concedido en leasing, el contrato es nulo. De todas maneras, las compañías de leasing se aseguran de que los bienes tengan una procedencia lícita, de que no se infrinja la Constitución y la ley en lo concerniente a la compra y venta de los bienes que se entregan o se van a conceder en leasing. No obstante lo anterior, surgen diversos interrogantes en aquellos supuestos donde los controles legales y reglamentarios que ejerce la compañía de leasing no logran detectar que los bienes tienen una procedencia ilícita o son producto de una operación de lavado de activos, por ejemplo. En este supuesto, se presentan dos hipótesis que vale la pena analizar aquí: a) Que la empresa de leasing posee bienes cuya procedencia es ilícita; y b) 
Que ya los concedió en leasing a varios empresarios. En ambos supuestos, la pregunta que cabe formularse, es la siguiente: ¿En caso de que el Estado realice una extinción de dominio por objeto ilícito, quién pierde los bienes, el empresario y usuario del servicio de leasing o, por el contrario, la sociedad especializada en el leasing? Este es un punto que tampoco ha sido debatido ni analizado por la doctrina nacional o extranjera en relación con el objeto ilícito en la enajenación de los bienes dados en leasing, o que se poseen para ser concedidos en leasing.

En mi criterio, la cuestión no es fácil de resolver desde el punto de vista jurídico en tratándose de bienes que hayan sido concedidos en leasing. ¿Por qué? Básicamente, porque, como primera medida, no hay debate o no puede haberlo en el supuesto en que la compañía tan sólo posea los bienes y no haya sido concedido en leasing a ninguna persona natural o jurídica (comerciante o sociedad mercantil) dichos bienes; sin embargo, si los bienes fueron concedidos o si ya se suscribió la escritura pública de compraventa por haber ejercido el derecho de opción, el bien se encuentra o en situación de tenencia por el comerciante o empresario usuario del leasing, o ya pasó a formar parte de los activos de una empresa que de buena fe los adquirió; en otras palabras, ya se materializó la transmisión del derecho de dominio sobre dichos bienes.

En el primer supuesto, esto es, cuando el empresario tan sólo explota los bienes en calidad de arrendatario, es un mero tenedor, en cuyo caso considero que sí hay objeto ilícito en el contrato porque se trata de bienes de dudosa procedencia o que son producto de actividades ilegales y de lavado de activos, la buena fe, es decir, el principio del error communisfacitjusprotege al empresario y debe ser la compañía a la se la extingan los bienes y sobre la que se deben ejercer las acciones de responsabilidad civil. Esto significa en una sana interpretación jurídica, que es la compañía de leasing la que debe perder los bienes, es decir, a la que el Estado está en su legítimo derecho de extinguirle los bienes otorgados en leasing. Además, el nuevo Código de Extinción de Dominio (Ley 1708 de 2014) en sus artículos $3^{\circ}$ y 95 dispone, de una parte, que el propietario o adquirente de 
buena fe debe ser protegido en sus derechos; y de otra parte, que en los contratos de arrendamiento el Estado respeta los derechos del arrendatario hasta la terminación del contrato. Por tanto, mi postura también se fundamenta en las normas anteriormente enunciadas.

De hecho, el artículo $3^{\circ}$ de la ley 1708 de 2014, prescribe: "La extinción de dominio tendrá como límite el derecho a la propiedad lícitamente obtenida de buena fe exenta de culpa y ejercida conforme a la función social y ecológica que le es inherente". Entre tanto, el artículo 95 del mismo estatuto, dice: "En el evento en que por sentencia judicial definitiva se declare la extinción de dominio o la devolución sobre un bien arrendado por administrador, el contrato continuará hasta el vencimiento del plazo pactado sin perjuicio de las previsiones legales y contractuales sobre terminación anticipada del contrato de arriendo. En caso de proceder la devolución física del bien, se efectuará la cesión del contrato de arrendamiento a la persona a quien se ordenó la devolución".

De acuerdo con lo expuesto, considero que si sobre los bienes que fueron entregados o concedidos en leasing el Estado ejerció una acción de extinción de dominio, el usuario o locatario está protegido por la presunción de buena fe, por el error común creador de derecho y por la última disposición del nuevo Código de Extinción de Dominio, que protege los derechos del arrendatario hasta la terminación del contrato, aparte de la cesión contractual correspondiente, sin perjuicio, como se indicó antes, de que el empresario pueda ejercer las acciones de responsabilidad civil contra la sociedad de leasing, si ésta le causó daños y perjuicios con la concesión u otorgamiento de bienes cuya procedencia era ilegal.

En armonía con los argumentos precedentes, sostiene el profesor WILSON ALEJANDRO MARTÍNEZ SÁNCHEZ (El nuevo Código de Extinción de Dominio, en la Revista Ámbito Jurídico Legis, 2014, p. 3) en relación con los terceros de buena fe, lo cual es perfectamente aplicable a los arrendatarios en un contrato de leasing: 
En relación con la protección de garantías constitucionales, se conserva el sistema conceptual y jurídico de protección a los terceros de buena fe. Esto significa que se reconocen como legítimos los derechos reales adquiridos por terceros de buena fe exenta de culpa, así en el pasado los bienes sobre los que recaen hubieran tenido origen ilícito o hubieran sido destinados a actividades ilícitas, tal como lo exige la Carta Política y la jurisprudencia de la Corte Constitucional.

Ahora bien, en lo que se refiere a los mecanismos procesales existentes para que estos puedan hacer valer sus derechos, el código es muchísimo más garantista que las normas vigentes, porque los terceros van a encontrar más y mejores mecanismos de protección para sus derechos.

(...) Sin embargo, hay que aclarar que, contrario a lo que han afirmado algunos colegas, el nuevo código es más garantista que la legislación vigente en relación con los terceros de buena fe exenta de culpa.

De otra parte, la sociedad de leasing, merced a su posición de dominio en el mercado y en el ámbito de la relación contractual con el consumidor y el empresario que acude al sistema de leasing, le asiste la obligación de un deber de información. En otros términos, la compañía de leasing está en la obligación de informar a sus clientes sobre la procedencia de los bienes que se van a conceder en leasing; esta obligación deriva del principio de buena fe, así como de la condición privilegiada que ostenta la empresa respecto de la persona natural o jurídica que celebra el contrato de leasing.

Así mismo, es una exigencia que tácitamente emana de los códigos de buen gobierno en materia empresarial (Ley 964 de 2005). La posición de dominio no sólo puede hacerse notar en la desproporción o desequilibrio contractual al redactar e imponer el clausulado del contrato, sino que también se traduce, en mi criterio, en el deber objetivo de cuidado respecto de los bienes y de la información 
que se le va a suministrar al usuario o comerciante interesado en adquirir bienes mediante esta modalidad. Por último, conviene añadir lo siguiente: si la sociedad de leasing actuó de buena fe, y no tiene responsabilidad respecto de los bienes que posee para ser otorgados en leasing; es decir, si habiendo actuado de buena fe, y habiendo revisado con detenimiento y debido cuidado la procedencia de los bienes, no logró establecer que se trata de bienes que proceden de actividades de narcotráfico, estupefacientes o lavado de activos. Es decir, si pese a haber realizado los controles no se pudo descubrir que dichos bienes tenían una procedencia ilegítima, y en definitiva, si se presenta objeto ilícito en la contratación sobre estos bienes.

A mi juicio, la buena fe se presume y la mala fe debe probarse, y la compañía de leasing está protegida por este manto de buena fe, en cuyo caso no se podrá realizar extinción de dominio sobre los bienes y propiedades de la sociedad de leasing, y por consiguiente, los terceros, esto es, los consumidores y usuarios del leasing no se podrán ver afectados por la supuesta ilicitud en el objeto. En todo caso, declarada la nulidad por objeto ilícito del contrato de leasing, no podrá repetirse lo que se haya dado o pagado a sabiendas. Y, si el contrato es prohibido por el ordenamiento jurídico interno, asimismo se predica el objeto ilícito del contrato de leasing, verbigracia, si se celebra sobre bienes de uso público o bienes que sean patrimonio cultural de la nación (Véase CASTILLO TRIANA, 1994).

¿Y en el caso leasing inmobiliario? El leasing habitacional o inmobiliario tiene como propósito contribuir al desarrollo social y a solucionar los problemas de vivienda de la población más vulnerable. De tal forma que constituye valioso instrumento para atender los problemas de acceso a vivienda digna a que se refiere el artículo 51 de la Constitución Política de 1991. "En el contrato de leasing habitacional, el objeto consiste en entregar un inmueble en leasing a cambio de un canon periódico, durante un tiempo previamente estipulado en el contrato, al final del cual el locatario tiene la opción de adquirir el bien por un valor residual" 
(OLARTE YEPES, 2005, p. 30). Si se decreta la extinción de dominio sobre dichos bienes inmuebles, prevalece, en mi criterio, el principio de buena fe, y de otra parte, priman los derechos y garantías sociales de los adquirentes sobre los derechos que en un momento pueda alegar el Estado para realizar la extinción de dominio. Se aplican los mismos criterios y principios que a los bienes muebles.

Ahora bien, y ¿qué ocurre si sobre los bienes otorgados en leasing son expropiados por el Estado, sea bienes muebles o inmuebles? Pienso que se pueden aplicar o que este problema jurídico se puede interpretar con base en los mismos derroteros anteriormente indicados para la extinción de dominio. Además, si la entidad de leasing es expropiada, el Estado está obligado a indemnizarla (Véase sobre expropiación empresarial LÓPEZ GUZMÁN, 2007). Si es al usuario o locatario, igualmente el Estado debe indemnizarlo en aras de no perjudicar los derechos de éste. Aunque se discute si la indemnización es en favor de la compañía de leasing o del arrendatario de los bienes. Considero que la indemnización debe realizarse en favor del empresario, pues es éste el que pierde el bien otorgado en leasing, y por tanto, es a él a quien se debe indemnizar, ya que se perjudica la actividad y desarrollo de la empresa. La empresa, según los artículos 58 y 333 de la Constitución Política de 1991 debe ser protegida, puesto que constituye fuente de riqueza y empleo para toda la comunidad (En el mismo sentido, véase DALLA VIA, 2000; LEGUIZAMÓN ACOSTA, 2000; LÓPEZ GUZMÁN, 2007; MORALES ALZATE, 2010).

Se puede pensar que es la compañía de leasing a la que se debe indemnizar, ya que ella es la propietaria de los bienes, y máxime si ésta no ha efectuado la venta en virtud de la opción de compra a que se refiere el contrato de leasing. Es el empresario el que pierde los bienes y quien se ve afectado en su desarrollo empresarial; al ser indemnizado puede continuar con la explotación del objeto social correspondiente, y la sociedad de leasing no ve perjudicado sus activos con esta situación. El Estado tiene derecho a expropiar en los términos previstos por el 
artículo 58 de la Constitución Política de 1991, pero está obligado a indemnizar el valor real, el precio del mercado de los bienes otorgados en leasing.

Si se trata de bienes embargados, el contrato adolece de objeto ilícito y, por ende, es nulo. Si los bienes son embargados por terceros que sean acreedores del empresario o del locatario, ¿Qué ocurre? ¿Contra quién se hace efectivo el embargo? Los bienes muebles o inmuebles otorgados en leasing son de propiedad de la sociedad de leasing, y el embargo y secuestro tan sólo se podrá solicitar por acreedores de dicha empresa, y no por terceros acreedores del empresario o locatario, pues tan sólo tiene la tenencia sobre los mismos, mas no la propiedad, y en el supuesto en que se realizara un embargo y secuestro sobre éstos, pienso que el empresario o locatario puede solicitar con base en este hecho que el juez los desembargue y le sean devueltos. Lo mismo ocurre, a mi juicio, en el marco de un proceso de insolvencia empresarial, conforme a la ley 1116 de 2006. Y de todas maneras, el artículo 21 de la mencionada ley, estipula la continuidad de toda clase de contratos en el escenario de un proceso de insolvencia empresarial. Eso significa que el contrato de leasing continúa ejecutándose en pos de mantener en estado de funcionamiento la empresa. Ésta debe pervivir, toda vez que es el corazón del sistema económico.

Como se explicó con anterioridad, el objeto se refiere a la prestación de dar el objeto o prestar un servicio en el contrato de leasing; aquí subyacen varias discusiones jurídicas que merece la pena precisar lo siguiente: en los contratos internacionales de leasing es menester tener en cuenta que dado que la legislación de cada país varía, es decir, es diferente, es evidente que en algunos Estados la comercialización de determinados bienes es válida en unos y prohibida en otros Estados. Igualmente, en el marco de la inversión extranjera (leasing internacional) se ha establecido en algunas legislaciones como la colombiana, que no se pueden importar bienes y maquinaria usados para utilizarlos en leasing, mientras que, por el contrario, en otras legislaciones es completamente válido. De otro lado, otro de los problemas jurídicos que de aquí se derivan gira en torno de 
la procedencia del bien y de la responsabilidad civil que de allí deviene. Respecto de la problemática que aquí se plantea es indudable que la jurisprudencia y la doctrina no se han referido al respecto; es decir, no encontramos en la doctrina y en la jurisprudencia local planteamientos en torno de estos valladares y situaciones jurídicas; por tanto, hay que acudir a los principios generales del derecho comercial, a la costumbre mercantil nacional e internacional y a las estipulaciones de las partes, aunque con las limitaciones de orden público señaladas en cada ordenamiento jurídico.

$\mathrm{Si}$ el bien que se pretende importar mediante leasing está prohibido por la legislación nacional pero $\mathrm{n}$ o por la legislación extranjera, no se puede ingresar a una empresa que tenga su domicilio en el territorio nacional. Desde esta perspectiva y en aras de respetar el orden público interno, el bien y/o la maquinaria concedidos en leasing no se pueden explotar en Colombia, pero sí se pueden explotar en un país donde se autorice la utilización de dicho bien o maquinaria. A mi juicio, es un criterio divergente sobre el que se debe pensar en una unificación a nivel regional y global, dado que la legislación nacional es sumamente restrictiva en perjuicio del desarrollo empresarial. De todas maneras, quiero resaltar que en Colombia este punto no ha sido discutido, ni mucho menos ha sido abordado por la doctrina y la jurisprudencia nacional. Ciertamente, la jurisprudencia local tan sólo se ha limitado a reproducir los conceptos legales y la doctrina local sin ahondar en los problemas jurídicos del leasing. En el derecho comparado tampoco encontramos mayores estudios sobre estos tópicos, por lo que nos hallamos ante un terreno jurídico francamente inexplorado, sin transitar, en el que asumimos una postura con base en los principios generales del derecho mercantil.

El objeto lícito se refiere, como es públicamente sabido en la ley, la jurisprudencia y la doctrina, a la actividad mercantil que se puede desarrollar sin contravenir el orden público de la nación, porque si se contraviene, el objeto se vuelve ilícito, es decir, en contra del orden público interno (Art. 1519 del Código Civil). Así, pues, 
dentro del examen de la naturaleza jurídica del contrato del contrato de leasing, dado que es menester, es imperativo examinar, estudiar los elementos y características, es igualmente imperioso abordar los requisitos de validez del negocio jurídico y disertar sobre sus implicaciones en el ámbito de leasing, así se amplía, se profundiza en la naturaleza jurídica y, por ende, se establecen posturas doctrinales al respecto (En el mismo sentido LÓPEZ GUZMÁN, RAVASSA MORENO, TAMAYO LOMBANA, SANÍN ESCOBAR).

\section{LOS DERECHOS COMO OBJETO DEL CONTRATO DE LEASING ${ }^{24}$}

\footnotetext{
${ }^{24} \mathrm{Vital}$, fundamental este aspecto, por cuanto los elementos son cosa, precio y objeto en el leasing. Generalmente se dice que el objeto es una cosa (bienes muebles, bienes inmuebles, verbigracia, el leasing habitacional, y bienes intangibles, como, por ejemplo, las nuevas tecnologías: marcas y patentes); sin embargo, nada se ha dicho sobre los derechos en el leasing, los derechos como objeto del contrato de leasing; es decir, como elemento del contrato, que como es sabido, es obvio, es indiscutible, es uno de los tópicos o aspectos que integra la naturaleza jurídica del contrato de leasing y de cualquier otro contrato mercantil nacional o internacional. Por ello, este desarrollo resulta de sumo interés en la doctrina contemporánea, ya que poco o casi nada se ha dicho al respecto; entendiendo que los derechos son también la cosa dentro del contrato, elemento $y$, a su vez, parte de la naturaleza jurídica del contrato.
} 


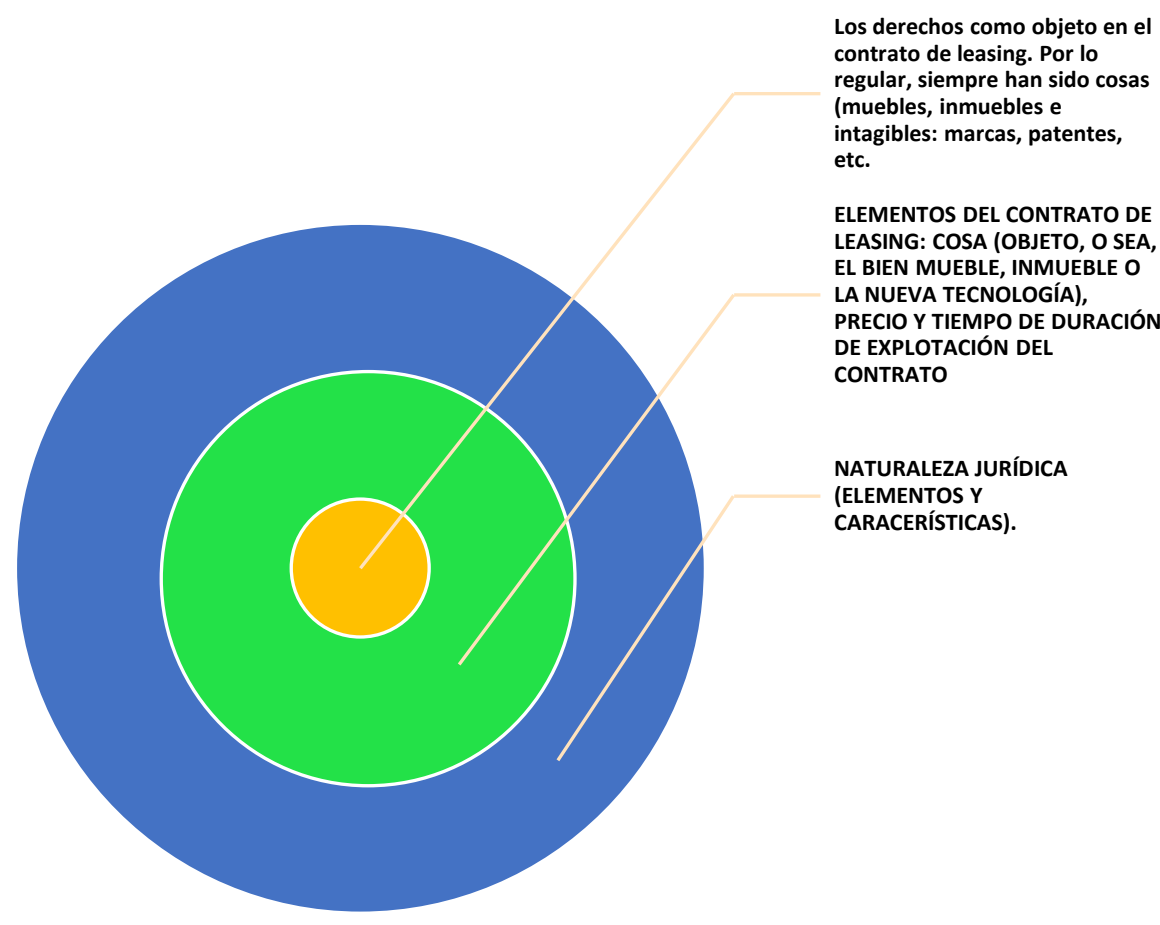

La legislación nacional es diáfana respecto de la posibilidad de conceder en arrendamiento financiero bienes muebles e inmuebles, y a este respecto no hay duda, pues cualquier clase de bien que pueda ser utilizado en la empresa o la industria puede ser concedido en leasing para su explotación y que esté destinado a la innovación empresarial, al perfeccionamiento de los procesos productivos y al mejoramiento en la calidad de los bienes y servicios que se le ofrecen al consumidor. Y la regla general es que se trate de bienes nuevos, no usados; sin embargo, considero que las sociedades de leasing pueden utilizar bienes ya usados, utilizados, para que otros empresarios los exploten, siempre y cuando se mantengan en buen estado y puedan ser empleados en la actividad mercantil para la cual fueron contratados mediante el sistema de leasing.

En torno de esta tesis existen posturas antagónicas. Personalmente soy partidario de que se puedan conceder en leasing bienes muebles o inmuebles usados, pero en el entendido de que sirvan para el propósito comercial para el cual fueron 
negociados en leasing, o sea, que se trate de bienes que puedan ser nuevamente utilizados, que se encuentren en buen estado de funcionamiento. Sobre este aspecto, señala la doctrina internacional (ACQUARONE y EMBON, 2004, pp. 129 $-130)$ :

Se ha discutido la posibilidad de celebrar contratos de leasing respecto de bienes usados. Existen precedentes extranjeros que se han mostrado contrarios a esta posibilidad. Atentos a la regulación legal que tiene el leasing en nuestro país, entendemos que no existen restricciones para que, respecto de bienes muebles usados, puedan ser celebrados contratos de leasing. Desde nuestro punto de vista, el tomador podría elegir una cosa nueva o usada, ya que ello no modifica la naturaleza del contrato. Inclusive en materia de leasing de inmuebles, nada obsta a que sean, por ejemplo, edificios reciclados. Respecto de las cosas consumibles, no parece que la posibilidad de someterlas a un contrato de leasing sea factible. LAVALLE COBO, con cita de VIDAL BLANCO, nos dice que es constitutivo de la esencia del leasing y su misma razón de ser, el que el bien, directa o indirectamente, se autofinancie, cualidad de la que, por regla general, no gozan los llamados bienes de consumo.

Empero, lo que amerita una discusión y un análisis jurídico, es lo concerniente a la posibilidad de explotar derechos sobre la propiedad intelectual en los contratos de leasing. En mi criterio, y utilizando una interpretación expansiva del contrato de leasing, considero que los bienes intangibles y los derechos sobre la propiedad industrial sí pueden ser susceptibles de ser contratados mediante la figura jurídica del leasing, o sea, sí pueden ser objeto de leasing.

Las marcas, patentes, el know-how, los diseños industriales y los modelos de utilidad están regulados en Colombia mediante la Decisión 486 de la Comisión del Acuerdo de Cartagena del año 2000. En efecto, esta decisión comunitaria regula ampliamente los bienes intangibles y los derechos sobre la propiedad industrial a que se hace referencia en este acápite. Sin embargo, en contra se puede argüir 
que la explotación de estos derechos se realiza mediante los contratos de licencia de patente y know-how y, por supuesto, mediante los contratos de transferencia de tecnología, pero no así por conducto de los contratos de leasing.

Por oposición, considero que nada obsta para que se celebren contratos sobre esta clase de derechos y sobre este tipo de bienes, y el hecho de que por lo regular la concesión sobre los mismos se efectúe a través de los contratos de licencia, no lesiona ni afecta los requisitos de existencia y validez del contrato de leasing ni desnaturaliza el negocio de leasing. Por tanto, a mi juicio, sí es factible que se puedan entregar esta clase de derechos y bienes intangibles en leasing, habida cuenta que la legislación mercantil no prohíbe ni limita, ni tampoco establece restricciones de ninguna naturaleza sobre el particular, y máxime que en hoy, en la era de la globalización, se destacan en el mercado las empresas del conocimiento, las empresas que se dedican a la investigación y al conocimiento mediante la explotación de patentes, know-how y marcas. Aunque los partidarios de que no es posible otorgar bienes intangibles y derechos en leasing, también sustentan su tesis en el hecho de que la explotación de los mismos, esto es, los negocios que permiten su uso y goce, se realizan por intermedio de los contratos de licencia de patentes y know-how, de licencia de marca. Ciertamente, por conducto de esta modalidad de contratos los empresarios pueden explotar innovaciones tecnológicas, y si lo que se hace en el contrato es conceder el uso y goce, reconociendo que el titular del derecho de dominio es otro sujeto mercantil, entonces no estaremos en presencia de un contrato de leasing sino de licencia o transferencia de tecnología, y en nada se diferenciaría del contrato de leasing.

En mi criterio, esto no es exactamente ajustado a la realidad comercial y de los negocios, ya que el contrato de leasing tiene diferencias con el contrato de licencia, no obstante que ambos en el fondo son una especie de contrato de arrendamiento. Pero ello mismos facilita la operación mercantil de leasing sobre los derechos y propiedad industrial, o sea, el hecho de que el tipo leasing se asemeje a una especie de contrato de arrendamiento, lo que en últimas se hace 
con este tipo de bienes y derechos, y además, ello ampliaría la negociación de esta clase de bienes, lo cual redundaría en beneficio de las empresas y, por ende, del desarrollo tecnológico de nuestro país, pues ya no solamente algunas empresas multinacionales ofrecen tecnología de avanzada, sino también las compañías de leasing del sector financiero. Es un mecanismo o instrumento jurídico que permite ampliar aún más la explotación de innovaciones tecnológicas; en otras palabras, como son escasas las empresas del sector privado que ofrecen nuevas tecnologías mediante los contratos de licencia de patente y know-how, licencia de software, resulta más conveniente para el mercado en general el sistema del leasing de la propiedad industrial.

La jurisprudencia nacional tampoco ha analizado este punto; de hecho, se hizo un estudio concienzudo de los diversos pronunciamientos jurisprudenciales sobre la posibilidad de otorgar bienes inmateriales en leasing y no se encontraron estudios jurisprudenciales sobre el particular. Más bien ha sido la doctrina internacional (España, Argentina, Chile, Francia y Estados Unidos) la que se ha atrevido a debatir el tema y el criterio mayoritario es que los bienes inmateriales sí pueden ser objeto de leasing. Coincido plenamente con este criterio en torno del objeto como elemento de la naturaleza jurídica del contrato de leasing; a mi juicio, en los contratos de leasing sí se pueden emplear bienes inmateriales, no obstante que por lo regular se utiliza la figura jurídica del contrato de licencia de patente, de marca y de knowhow, nada obsta para que se hable de leasing de patente y leasing de marca.

\section{ABUSO DE POSICIÓN DOMINANTE EN EL CONTRATO DE LEASING}




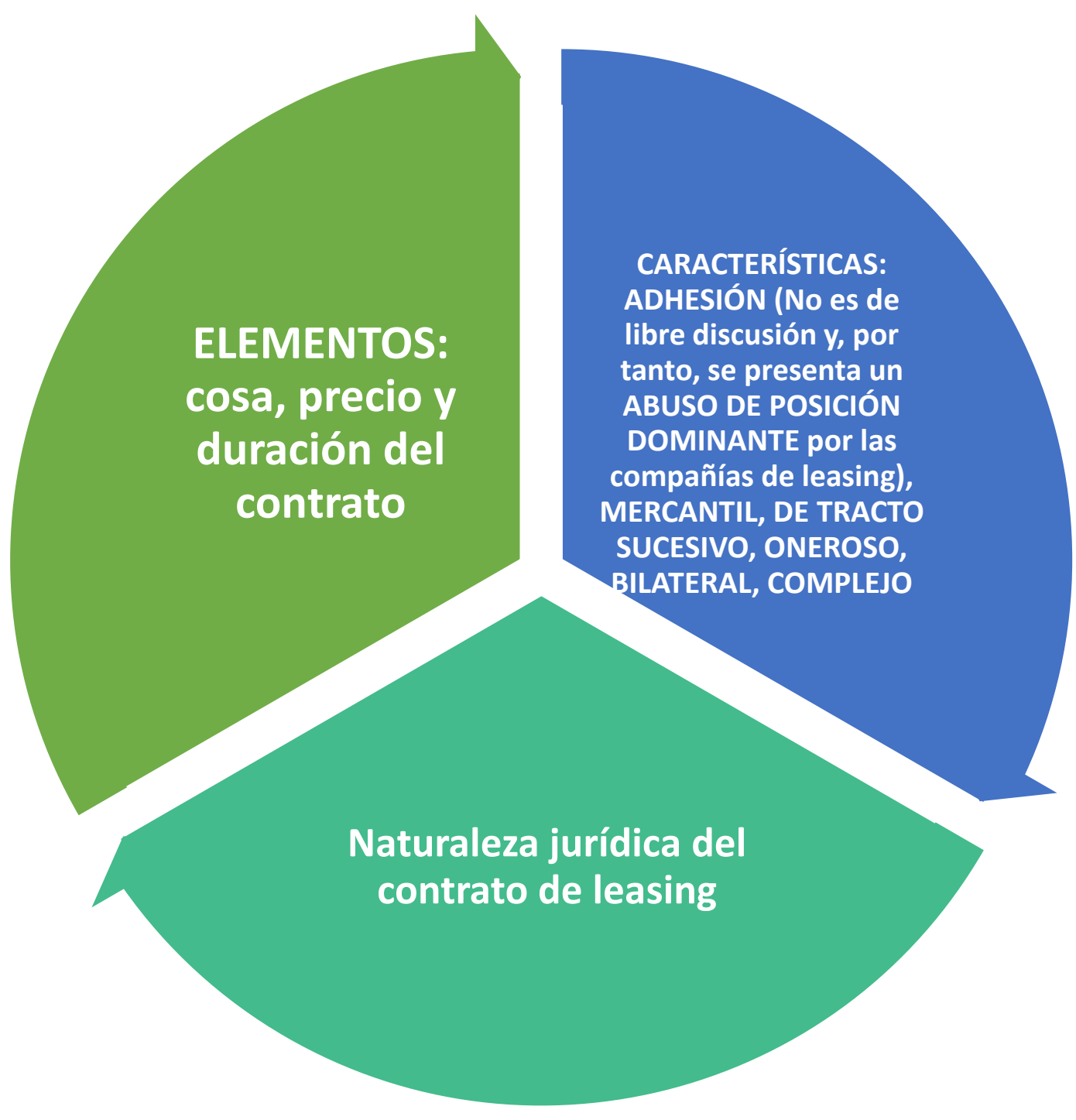

El abordaje del tema de la posición dominante dentro del contrato de leasing, no sólo resulta de vital interés, sino que, además, se justifica plenamente, por cuanto la posición de dominio hace que el contratosea de adhesión y no de libre discusión, que es una de las características del contrato, aspecto integrante de la naturaleza jurídica. En este orden de consideraciones, es un problema fundamental que hay que abordar en forma obligatoria dentro de la investigación y la disertación sobre la naturaleza jurídica del leasing. Sobre el abuso de posición dominante es mucho lo que se ha escrito en el derecho privado comparado; asimismo la legislación sobre la materia es sumamente amplia y detallada. 
Primero fue Estados Unidos y luego la Unión Europea quienes se aventuraron en un primer esfuerzo legislativo tendiente a paliar los abusos y las prácticas monopolísticas de algunos sectores económicos, en especial en el ámbito de la fabricación y distribución de licores, y luego en el contexto del acero y la industria extractiva (petróleos y minería).

Y esta teorización sobre el abuso de posición dominante se fue perfeccionado y desarrollando en el panorama contractual, concretamente en lo concerniente al clausulado del contrato. Fue allí donde se empezó a hablar no ya de contratos consensuales y de libre discusión como legítimos desarrollos del postulado de la autonomía de la voluntad, en virtud de la libertad económica y libertad contractual, sino de contratos en masa, donde las condiciones comenzaron a ser preestablecidas por la parte dominante en el contrato; y no es que la ley colombiana sanciones per se la posición de dominio, pues ostentarla no convierte al contrato en nulo o violatorio de las normas del derecho del consumo o de la competencia, sino que, por el contrario, lo que se sanciona es la conducta abusiva propiamente dicha.

Por ello, la Constitución política de 1991 en su artículo 333 nos habla de que la sanción se establece es en la persona natural o jurídica que abusa de su posición de dominio y no de quien simplemente ostenta una posición de dominio en el mercado. Ciertamente la disposición mencionada, estipula en el aparte correspondiente:

“(...) El Estado, por mandato de la ley, impedirá que se obstruya o se restrinja la libertad económica y evitará o controlará que personas 0 empresas hagan de su posición dominante en el mercado nacional".

Pero aquí viene una discusión jurídica de larga tradición en el derecho privado comparado, y es la siguiente: ¿Acaso quien ostenta una posición de dominio en el mercado no se siente por lo regular tentado a imponer sus condiciones y a 
aprovecharse de su condición en la libre competencia económica y a imponerse sobre el consumidor que, por lo general, es la parte débil en la relación contractual? Esta discusión o esta pregunta se ha planteado en diversas oportunidades y parece que la conclusión a que con frecuencia se suele llegar es la misma: sí, en efecto, la posición de dominio es una dulce tentación para los empresarios o para el grupo de empresas que la posee en un mercado determinado, en una zona o en un país, no hay duda, y el ejercicio de esa posición es lo que permite la subsistencia de una compañía en el mercado, porque el juego de la libre competencia económica se realiza entre los más fuertes en el mercado.

No voy a referirme aquí al abuso de posición dominante en el contexto del derecho de la competencia, sino en particular al contrato de leasing, con base en el problema jurídico planteado al comienzo de esta investigación, desde la perspectiva jurídica de su naturaleza. Ciertamente, lo primero que hay que tener en cuenta, es que las compañías de leasing ostentan una posición de dominio respecto del usuario del sistema financiero o potencial locatario. A la luz de la ley 1480 de 2011, actual Estatuto del Consumidor, el locatario es un usuario del sector financiero. Por tanto, al arrendatario o locatario se le aplican las disposiciones sobre derecho del consumidor; en consecuencia, está protegido por estas disposiciones legales, verbigracia, la regulación sobre cláusulas sobre exoneración de responsabilidad y las cláusulas abusivas. Como es sabido, en los contratos de leasing, dada la posición de dominio de la compañía de leasing, es frecuente que se incluyan cláusulas de este tenor.

Por lo común, el clausulado del contrato de leasing está rodeado de este tipo de estipulaciones; son condiciones que están en detrimento de los derechos del locatario, que generan un desequilibrio contractual y, por ende, un perjuicio en cabeza de éste. Cláusulas que indican que la única responsable por la calidad del bien que se concede en leasing es la compañía productora, o en las que se manifiesta que cualquier daño o deterioro que se produzca en el bien debe ser solucionada o garantizada por el productor, por el representante comercial de la 
empresa que vende y distribuye el bien concedido en leasing, o inclusive por la empresa titular de la marca, y que exoneran por completo a la compañía de leasing, constituyen un evidente abuso del derecho y se inscriben dentro de este tipo de cláusulas. Asimismo, disposiciones contractuales en las que se somete al usuario a la jurisdicción arbitral, excluyendo la posibilidad o la facultad que éste tiene de acudir o acceder a la jurisdicción común, son frecuentes en esta clase de contratos. La cláusula arbitral no puede ser impuesta, o cláusulas engañosas en las que se publiciten determinados servicios y asistencia para la maquinaria adquirida en leasing que más tarde no van a cumplir, son tipos corrientes de esta clase de cláusulas en los negocios de leasing.

De ahí que restricciones de esta índole en los contratos de leasing, afectan el equilibrio del contrato $y$, por supuesto, permiten concluir que este contrato no es de libre discusión como por lo regular lo asevera la mayoría de la doctrina, sino que, por el contrario, son de adhesión, puesto que se celebran en masa, y las condiciones predispuestas en el mismo se imponen al consumidor sin más discusiones o dubitaciones.

\section{LA MATERIALIZACIÓN DE LA POSICIÓN DOMINANTE EN EL CONTRATO DE LEASING.}

Como es sabido, en el contrato de leasing es la parte fuerte o la denominada parte dominante la que redacta el clausulado del contrato, con lo cual, en caso de controversia entre las partes, dichas cláusulas se deben interpretar a favor de la parte que no las redactó; es decir, de la empresa que contrata el servicio de leasing; y por ende, la parte fuerte se ve limitada por la interpretación restrictiva 0 en contra que hace el juzgador en caso de que las cláusulas sean confusas. Este criterio es un concepto general de la legislación civil y mercantil que, como es sabido, se reitera en el derecho privado comparado. La cuestión que aquí se 
plantea de entrada, es que el clausulado del contrato es redactado por la parte dominante en el contrato, esto es, por la compañía que ofrece el servicio de leasing, y este es un hecho inocultable, inobjetable, pues un empresario o un comerciante no se sienta con la compañía a discutir cada una de las condiciones y cláusulas del contrato, sino que las lee y las acepta en el momento en que decide suscribir el contrato de leasing respectivo. Así pues, prima facie la posición de dominio empieza desde el momento en que las partes suscriben el contrato, pues el formato ya viene prediseñado, pre elaborado por la empresa de leasing. Entonces, cuando la mayor parte de la doctrina (BONIVENTO FERNÁNDEZ, ARRUBLA PAUCAR, GHERSI) sostiene que es un contrato de libre discusión. Sea lo primero advertir que el yerro se funda en el hecho de que el leasing es un contrato en masa, netamente empresarial, a diferencia de los contratos civiles, que se celebran en forma individual. Los contratos mercantiles se celebran a gran escala, y al perder de vista este aspecto esencial, axial de la contratación mercantil, se piensa que todos los contratos siguen la misma línea, o están estructurados bajo el mismo principio de autonomía de la voluntad y libre discusión a que se refiere el artículo 1602 del Código Civil colombiano. Y la verdad es que este contrato, está nutrido por una concepción diametralmente opuesta, la de ser mercantil, en masa, y no hay lugar para abrirse al debate jurídico sobre su clausulado, dado que el control judicial que sobre ellas se pueda hacer es posterior, ante la Superintendencia de Industria y Comercio, ante los jueces, o ante un tribunal de arbitramento si así se convino o pactó dentro del contrato. Es más, como se trata de un contrato estándar, es la Superintendencia Financiera la que establece las pautas, guías o directrices a tener en cuenta en la contratación con los particulares, y lastimosamente, muchas de estas directrices jurídicas y financieras se diseñan en menoscabo de los derechos del usuario del sistema financiero del leasing.

Aparte de la problemática subyacente a la redacción, al contenido y, por supuesto, a los efectos jurídicos de dicho clausulado, así como a la imposibilidad real y práctica de discutir, de controvertir el contenido del contrato, lo que lo aleja de ser 
un contrato de libre discusión - tesis decimonónica del contrato - y lo acerca indudablemente a un contrato de adhesión, hay otros aspectos de igual relevancia que lo apartan de la concepción primigenia de libre discusión.

Veamos:

La estipulación de condiciones discriminatorias para operaciones equivalentes, que coloquen al empresario que celebra el contrato de leasing en situación desventajosa frente a la misma compañía o proveedor de condiciones análogas.

Esta conducta se considera a todas luces como posición de dominio en el contrato, conforme al artículo 50 del Decreto 2153 de 1992, en armonía con lo dispuesto en las directivas y en el tratado constitutivo de Roma de 1957; es decir, en el derecho europeo de la competencia y de la contratación. Analicemos la siguiente cláusula: la compañía LEASING TOTAL en su modelo de contrato dice en su artículo 5.2 lo que se indica enseguida: "Será total y exclusiva responsabilidad del cliente y sin que genere responsabilidad para leasing total: a) cualquier diferencia que pudiera surgir con relación a las características y calidad técnica de los bienes determinados por el cliente; b) eventuales vicios 0 deficiencias de los bienes, o disconformidad respecto al contrato de compraventa de los bienes; c) eventual incumplimiento, demora y/o falta de entrega de los bienes por los proveedores de los mismos.

Desglosemos el punto: en primer término, dicho clausulado es nulo por abusivo, por estipular condiciones desfavorables o que colocan al empresario en situación de desventaja. El riesgo del clausulado abusivo en el leasing es comentado por la doctrina (MARTíNEZ CAMARGO y DE LEÓN NOVOA, 2013, p. 38) en los términos que se indican a continuación:

(...) El análisis de las cláusulas abusivas se puede encontrar en los contratos de leasing, tales como la responsabilidad de la sociedad de 
leasing por defectos de calidad o vicios ocultos y lesión enorme del bien objeto del contrato. Puede decirse que es sensible el evento en el bien cuya tenencia entrega la leasing presenta un defecto de calidad o se revela un vicio que había permanecido oculto y luego el locatario se dirige a la sociedad de leasing para que adopte las medidas pertinentes o según el caso, la convocan a juicio en ejercicio de las acciones que la ley otorga para tales eventos.

Normalmente, de acuerdo a lo investigado, la sociedad de leasing rechaza la reclamación y se opone a la demanda, alegando que no tiene responsabilidad por esos hechos, pues obra como un simple intermediario y además, en el contrato fue eximido de esos débitos, a lo que añade que es el proveedor del bien el que debe realzar la garantía o acudir al saneamiento.

Sin embargo, cuando el locatario demanda con ese propósito al proveedor, este en la mayoría de las veces responde que no celebró ningún contrato con él, pues su comprador fue la sociedad de leasing. Si se miran bien las cosas, esta controversia es propia del leasing financiero, en el que, ciertamente, la sociedad de leasing funge como intermediario en el proceso de adquisición del bien.

Ahora bien, conviene detenerse en el clausulado anteriormente enunciado en el modelo de contrato aludido. La responsabilidad concerniente a la calidad y características técnicas del bien dado en leasing no se debe trasladar al cliente, porque precisamente lo que éste busca, lo que pretende es recibir un bien en óptimas condiciones para ser utilizado, y si bien es cierto que la responsabilidad se quiere endilgar a la empresa proveedora o al mismo cliente, significa ni más ni menos, la exoneración de responsabilidad a cargo de la empresa dadora, de la compañía de leasing propiamente dicha, lo cual atenta gravemente contra cualquier régimen de responsabilidad. En un mundo cambiante, globalizado, 
donde el servicio está centrado en el cliente, y donde la responsabilidad civil ha transitado de la órbita subjetiva a la objetiva, resulta un contrasentido, un despropósito, y por ende, un abuso del derecho que las características y la calidad, así como la responsabilidad derivada de ello sea traspasada al cliente, al empresario, que precisamente hace una inversión o erogación para adquirir un bien. Ello no sólo riñe con los más elementales principios de responsabilidad civil (cláusula exonerativa) ${ }^{25}$, sino que además, menoscaba los derechos y garantías mínimas del ciudadano, del empresario, y está en contravía de los postulados constitucionales como el de buena fe, equilibrio contractual, equidad, solidaridad, autonomía y libre iniciativa privada, al margen de que en forma directa o indirecta se erige en una forma de lesionar el derecho a la propiedad del empresario.

Aparte de lo anterior, la mencionada cláusula limita la responsabilidad en cabeza suya por los vicios en la compraventa y por la calidad o la mora del proveedor, lo cual también se estructura en contrasentido, y en una evidente posición de dominio respecto del usuario o tomador del leasing. Lo lógico, desde una

\footnotetext{
25“De este modo parece ser más apropiado sostener que las cláusulas de exoneración y limitación de responsabilidad se refieren a la asunción por parte del deudor de toda o alguna consecuencia o efecto que se derive de la inejecución de la obligación. De esta manera, de forma amplia se podrá limitar la responsabilidad, por el grado de la culpa, o limitar los efectos del incumplimiento.

"Por ello se comparte una segunda teoría según la cual las cláusulas de limitación y exoneración de responsabilidad actúan sobre el régimen de la responsabilidad y que el efecto de la limitación no se manifiesta con exclusividad al momento de la cuantificación del daño, sino también durante el amplio espacio del incumplimiento imputable. Esta posición se apoya también en que el término responsabilidad en un solo vocablo sintetiza toda una compleja disciplina. Al compartir esta segunda tesis, este hecho conlleva a que se comparta la posición por la cual se sostiene que a los límites de validez que se aplican a las cláusulas de exoneración y limitación de responsabilidad, también se deberán someter todas aquellas cláusulas que produzcan como efecto de manera directa o indirecta una limitación o exoneración de responsabilidad, posición que se apoya en la aplicación del principio general de buena fe objetiva como una cláusula general, principio este que en tema de cláusulas restrictivas de responsabilidad se analizará y aplicará con un criterio independiente de la intención subjetiva de los contratantes" (GUAL ACOSTA, 2012, pp. 106-107).
} 
perspectiva jurídica moderna, es que la compañía de leasing se haga responsable de lo que ofrece, de la calidad del bien, de la mora en la entrega. Es frecuente que ante esta problemática concreta, real, que ocasiona múltiples litigios, el usuario o consumidor se pregunte cómo puede proteger sus derechos frente a este tipo de cláusulas abusivas. La legislación colombiana es nítida, diáfana sobre el particular, y plantea soluciones que a la postre son incompletas, insuficientes y que, en definitiva, no redundan en beneficio del usuario o del empresario que accede a estas compañías de leasing para obtener un bien o una maquinaria para su compañía y mejorar los bienes y servicios que se producen y ofrecen al consumidor. Ciertamente, las soluciones legales consisten en instaurar un proceso ordinario, conforme al Código de Procedimiento Civil, buscando probar la responsabilidad de la compañía, y además, pretendiendo configurar el abuso del derecho y la posición dominante en el contrato, además de la abusividad en el clausulado del contrato de leasing. Situación bastante compleja, difícil, y por supuesto, onerosa para el empresario que toma el leasing. Litigar cuesta, vale dinero, e implica un esfuerzo adicional para el empresario que se ve envuelto en un proceso para hacer efectivos, materiales sus derechos personales, económicos y constitucionales. El grave inconveniente de esta situación, o de esta solución o alternativa procesal, es que el proceso es dispendioso, largo, tortuoso e incierto en cualquiera de las instancias, aparte del hecho de que acudir en casación es aún más complicado e incierto para las partes. Hoy, según el Código General del Proceso, la reclamación se tramita por intermedio de un proceso verbal; sin embargo, este código no ha entrado en funcionamiento en su totalidad, por lo que se debe continuar con el antiguo trámite del proceso ordinario.

La otra solución es acudir ante la Superintendencia de Industria y Comercio para que ésta declare mediante proceso verbal la abusividad e imponga las sanciones económicas de rigor, verbigracia, multas, etc. Sin embargo, qué es una multa para una entidad financiera que recibe ingentes cantidades de dinero y utilidades por el negocio de leasing. La última alternativa son los tribunales de arbitraje comercial. Como es sabido (PAZ RUSSI, MARTíNEZ NEIRA, CORREA ARANGO, GIL 
ECHEVERRY), una controversia se puede ventilar ante un tribunal de arbitramento previa cláusula compromisoria, o mediante la figura jurídica del compromiso. La cuestión es que los contratos de leasing traen por lo regular una cláusula de solución de controversias que se denomina pacto arbitral (Ley 1563 de 2012), por medio de la cual todos los conflictos que surjan con ocasión de la celebración, las obligaciones, efectos o interpretación del contrato de leasing deben ser resueltos ante la justicia arbitral.

No cabe duda que la justicia arbitral en Colombia se ha ejercido con responsabilidad, que la mayor parte de quienes fungen en calidad de árbitros son juristas probos, con amplia experiencia y reconocimiento, y que la justicia arbitral es pronta, eficaz y busaca ante todo la realización de los principios de justicia y equidad; sin embargo, el primer valladar para el empresario que debe litigar ante la jurisdicción arbitral es el concerniente a los costos elevados de litigar ante esta justicia; para nadie es un secreto que la jurisdicción arbitral es costosa, compleja, y que para reclamar, el empresario debe estar acompañado de una importante firma de abogados o de un experto en las lides del arbitraje comercial. Esta cláusula es también abusiva en la medida en que niega el acceso a la administración de justicia al empresario, al efectuar dicha limitación. En general, las soluciones procesales que ofrece la legislación colombiana no son contundentes, porque por ejemplo no implican de entrada el cierre del establecimiento, la sanción económica a los gerentes o representantes de dichas entidades de leasing, ni sanciones de carácter penal. Por ello, los mecanismos procesales para litigar por cláusulas exonerativas y abusivas de responsabilidad en los contratos de leasing son limitados, son insatisfactorios para el cliente.

Ante esta circunstancia, no cabe duda que el contrato de leasing es puramente de adhesión y no de libre discusión; es inobjetable, es así, es la realidad que vive el empresario en su actividad comercial cotidiana, lo demás son apreciaciones conceptuales de la doctrina que distan de la realidad comercial y de los negocios. 
De ahí que mi propuesta esté orientada a que se analicen los siguientes puntos 0 posibles soluciones:

Como primera medida, la responsabilidad contractual en el contrato de leasing debe ser objetiva, debe volverse puramente objetiva, y la carga de la prueba debe estar en cabeza de la entidad o compañía de leasing. No hay norma expresa que atribuya en materia financiera y comercial una responsabilidad de raigambre objetivo en los contratos de leasing. Ciertamente, se vacila mucho al respecto, existen múltiples decretos y disposiciones, pronunciamientos jurisprudenciales varios (Corte Suprema de Justicia, Corte Constitucional), pero centrados en otras discusiones jurídicas, principalmente en los aspectos tributarios del contrato de leasing, con objeto de hacer más rentable el negocio para el Estado y el mismo sistema financiero.

De otro lado, el denominado defensor del consumidor financiero debe desaparecer, no sirve, es una falacia enorme. Es absurdo, ilógico que un funcionario que percibe salario de la misma entidad financiera tenga las suficientes facultades y atribuciones legales para sancionar en debida forma a una compañía de leasing. Este defensor es un trabajador, un empleado más al que cualquier día le terminan el contrato sin más explicaciones. El defensor del usuario financiero, encargado de equilibrar el contrato de leasing, en particular por el clausulado abusivo, debe ser una entidad autónoma, una Organización o cualquier organismo o persona jurídica con respaldo del Estado y con suficientes atribuciones para sancionar a las compañías de leasing que incurran en esta clase de conductas. De lo contrario, es pura burla, es un mito, una figura jurídica decorativa y un engaño para el empresario.

Además de lo anterior, las sanciones por cláusulas abusivas, merced a que es un contrato de adhesión, deben ser mucho más severas, más estrictas o rigurosas, como, por ejemplo, de carácter penal, de cierre definitivo del establecimiento de leasing, amén de las sanciones directas y pecuniarias que deben tener los gerentes y representantes legales por esta clase de estipulaciones contractuales. 
Ciertamente, la ley 964 de 2005 avanzó a pasos agigantados con el denominado Código de Buen Gobierno; sin embargo, es insuficiente, faltan mecanismos procesales que le permitan al usuario defender sus derechos en formas más ágil, real y adecuada, por ejemplo, permitiendo o autorizando el embargo y secuestro de los bienes y derechos de la entidad de leasing; esto no está permitido en la legislación, a menos que se trate de un proceso ejecutivo, con base en una obligación clara, expresa y exigible. Así mismo, posibilitar la extinción de la entidad o de los bienes de ésta, o inclusive, posibilitar que en virtud de este tipo de cláusulas abusivas en el contrato de leasing se autorice al usuario a retener 0 adquirir directamente los bienes dados en leasing, merced a estos abusos y estipulaciones que desbordan el régimen supérstite de responsabilidad civil.

De todas maneras, para mitigar las conductas lesivas en el contrato de adhesión de leasing, el legislador ha diseñado mecanismos jurídicos y procesales de protección como las cláusulas abusivas, el abuso del derecho y, en general, los principios generales del derecho mercantil (buena fe; favor negotti; enriquecimiento sin causa; desequilibrio económico contractual, entre otros). En este orden de ideas, mediante la acción de tutela, la acción de grupo, las acciones civiles (reparación por daños y perjuicios, incumplimiento de contrato, abuso del derecho) se equilibra el juego de fuerzas entre la compañía de leasing y el empresario que requiere el bien o maquinaria. Desde el punto de vista jurisprudencia, vale la pena subrayar que la jurisprudencia local no ha analizado esta discusión jurídica, esta problemática, por lo que no podemos decir que existan derroteros comunes o lineamientos jurisprudenciales al respecto, hay un verdadero vacío en esta materia.

En estas condiciones, lo más aconsejable es acudir al derecho comparado, verbigracia, el derecho francés o español, donde el consumidor y el empresario (usuario de los bienes y servicios del mercado) ocupan un sitio clave dentro del sistema jurídico, son el eje del sistema económico, del mercado, por ende, se les debe proteger, incluso si es menester sancionar a las compañías de leasing. 
Evidentemente, ante el espacio vacío a nivel doctrinal, opino que el derecho de la competencia y el régimen de cláusulas abusivas, permite equilibrar, ponderar 0 paliar las situaciones de abuso dentro de los contratos de leasing. En general, es un tema, un escenario vacío en el que igualmente nos debemos remitir a los principios del derecho antimonopolio y de cláusulas abusivas para ir creando o constituyendo en forma paulatina un acervo jurisprudencial sobre la materia.

El consumidor, esto es, el locatario del sistema de leasing es al que se le debe proteger en esta relación comercial, pues al fin y al cabo es la parte débil en el contrato, y la inclusión de cláusulas abusivas e ilegales tan sólo benefician a la compañía de leasing y perjudican seriamente al consumidor o locatario. Habida cuenta que la compañía de leasing ejerce una posición de dominio, el contrato es de adhesión y no de libre discusión, y esta situación se logra paliar o controlar por vía judicial y administrativa acudiendo ante los jueces para que declaren la nulidad de las cláusulas abusivas, y ante la Superintendencia de Industria y Comercio para que declaren la ineficacia e ilegalidad de las mismas. Ahora bien, en el leasing internacional se aplican las normas más favorables al consumidor, es decir, las normas o el ordenamiento jurídico donde habitualmente reside el consumidor, conforme al Convenio de Roma de 1980 sobre Obligaciones Contractuales Internacionales. En el mismo sentido el Convenio de México de 1994, en armonía con el Convenio de Ottawa sobre leasing internacional, donde prima la voluntad de las partes.

\section{CONCLUSIONES}

1. El contrato de leasing es un negocio jurídico de adhesión y no de libre discusión, es decir, no es consensual como lo sostiene gran parte de la doctrina, puesto que la compañía de leasing ya tiene un formato prediseñado que es el que le suministra a la empresa que está interesada en utilizar el servicio y contratar para usufructuar los bienes y nuevas tecnologías y contar con la opción de compra. Las cláusulas predispuestas, 
la posición de dominio en el mercado de estas compañías respecto del usuario y el desequilibrio en la relación contractual hacen de este negocio jurídico un típico contrato de adhesión y no de libre discusión, como lo considera la mayoría de la doctrina nacional. Es falso, es ingenuo pensar como lo hace la mayoría de la doctrina en Colombia, que el contrato de leasing es un negocio jurídico de libre discusión, pues no cabe duda que la compañía de leasing siempre termina imponiendo sus formatos y, por consiguiente, sus condiciones dentro del contrato, sus cláusulas, cuya única manera de mitigar es mediante el derecho antimonopólico y el régimen de cláusulas abusivas. La jurisprudencia calla al respecto. La jurisprudencia local es tan solo un áulico de la ley y de la doctrina local, no hace mayores análisis, no presenta mayores debates jurídicos y mucho menos podemos creer que ha creado criterios diferenciadores al respecto.

2. El contrato de leasing cumple hoy una función social y no sólo económica, merced al hecho de que la economía contemporánea está transitando hacia un capitalismo global con carácter social. La mayor parte de la doctrina se refiere a la función económica pero no a la función social, y es aquí donde la doctrina local (RAVASSA MORENO, 2004) sí ha dado un importante viraje en esta materia, pues resalta el hecho de que la empresa cumple hoy una verdadera función social, igualmente el contrato, y que la principal característica de éste en el derecho del siglo XXI es la cooperación, la solidaridad; hacia allí apunta el nuevo derecho mercantil, por consiguiente, la función social está más allá de la función económica, y está acorde con la filosofía constitucional. De hecho, la Corte Constitucional tiene un amplio desarrollo jurisprudencial sobre la función social de la empresa (MORALES ALZATE, 2012), pero no específicamente sobre sobre el contrato de leasing, y la jurisprudencia local ha sido puramente descriptiva mas no problemática ni creativa en torno de esta figura jurídica.

3. Es menester incluir la lesión como vicio del consentimiento dentro del contrato de leasing para que el usuario cuente con otras herramientas adicionales para defender sus derechos ante la parte fuerte en el contrato, 
o sea, la compañía de leasing. Además de la posibilidad de acudir ante la Superintendencia de Industria y Comercio para reclamar por cláusulas abusivas, se debe erigir o posibilitar el camino para la acción rescisoria por lesión, pero por vicio del consentimiento, conforme al ordenamiento privado comparado, verbigracia, el derecho privado alemán, italiano y francés, donde sí se permite rescindir el contrato por lesión, ya que ésta se considera un vicio del consentimiento. La doctrina y la jurisprudencia local no han analizado este punto a fondo, se trata de un terreno inexplotado en Colombia, pero en el que hay que empezar a generar cambios legislativos y de concepción. En mi criterio sí se debe extender la lesión al contrato de leasing, al margen de que en la actualidad tan sólo se aplique a los bienes inmuebles, y al margen del hecho de que en nuestro sistema jurídico no se aun vicio del consentimiento. Es indudable que un viraje en esta materia permitiría una mayor evolución de la figura en nuestro medio.

4. El contrato de leasing es hoy un contrato típico y no un contrato atípico como lo sostiene la mayoría de la doctrina en Colombia, puesto que la legislación sobre el particular es sumamente abundante, completa y detallada, al margen de que el Código de Comercio no lo haya regulado. Y ese hecho no lo convierte per se en un contrato atípico, ya que la legislación mercantil no se constriñe exclusivamente al Código de Comercio, sino que abarca otra serie de normas y disposiciones. De hecho, el Código de Comercio en su artículo $1^{\circ}$ establece que la ley comercial es la fuente principal del derecho mercantil y que es cualquier disposición o norma que regula la actividad y operaciones mercantiles que desarrollan los comerciantes. Así, pues, el contrato de leasing está desarrollado, tipificado, normativizado por la legislación mercantil. A esta época es mucho lo que se ha legislado sobre este tipo de contrato, independientemente de que la legislación sea variada y esté dispersa; en verdad, ello no es un contrargumento para desechar la idea de que se trata de un contrato típico. 
5. El objeto y la causa en el contrato deben ser lícitos; la ilicitud en la causa y en el objeto hacen que se presente una solidaridad en la responsabilidad contractual, o sea, son corresponsables la empresa de leasing y el usuario, y no exclusivamente el usuario como lo ha presumido un sector de la doctrina nacional.

6. El contrato de leasing no debe ni puede confundirse con otras figuras contractuales con las que guarda cierta similitud, verbigracia, el contrato de arrendamiento, la compraventa con pacto de retroventa o el mandato; el contrato de leasing tiene características propias, es un contrato eminentemente internacional, que nació de los usos y costumbres mercantiles.

7. Se debe generar un mayor equilibrio en el contrato en aras de proteger los derechos del consumidor y aplicar en los contratos de leasing de preferencia la legislación más favorable al usuario, esto es, la legislación interna colombiana, que es el lugar donde se va a explotar el patrimonio o los bienes concedidos en leasing. Al contrato de leasing se le aplican normas internacionales cando es celebrado entre partes que tienen establecimientos ubicados en distintos Estados. Rige la ley del país o el ordenamiento jurídico del Estado donde se encuentre ubicado el inmueble, conforme al Convenio de Roma de 1980 sobre obligaciones y contratos internacionales, en consonancia con lo que establece el artículo 20 del Código Civil colombiano. En tratándose de bienes muebles se aplica la lay elegida o escogida por las partes; sin embargo, es menester tener en cuenta que la ley aplicable al contrato internacional celebrado con consumidores (locatarios y usuarios del sistema de leasing, es la ley donde habitualmente reside el consumidor), a fin de equilibrar o mitigar los posibles abusos que se puedan cometer con el locatario y usuario del sistema de leasing. Aunque, curiosamente, en muchas ocasiones resulta más favorable la legislación del país de la compañía de leasing, habida 
cuenta que algunos sistemas jurídicos ofrecen mayor seguridad jurídica, mayor blindaje contractual, mejor organización, eficiencia y sistema judicial - arbitral que la legislación del país donde habitualmente reside el consumidor, es decir, el locatario.

\section{BIBLIOGRAFÍA}

- AA.VV., (1999): Contratación internacional, Valencia, Editorial Tirant lo Blanch.

- AA.VV., (1997): Contratos internacionales, Madrid, Editorial Tecnos.

- ACQuARONE, maría T., y EMBON, LEONAERDO G (2004): El leasing. $\mathrm{Su}$ instrumentación y encuadre en la actual financiación empresaria, Buenos Aires, Editorial Ábaco de Rodolfo Depalma.

- ALMONACID SIERRA, JUAN-JORGE y GARCía LOZADA, NELSON GERARDO (1998): Derecho de la competencia, Bogotá, Legis Ediciones.

- Alterini, atilio aníbal y lópez cabana, ROBERTO M (2000): "Contratos atípicos", en AA.VV., Contratación contemporánea, Lima - Perú, Editorial Palestra - Editorial Temis.

- ÁlVAREZ-CORREA DUPERLY, EDUARDO (1991): Contratos bancarios, Bogotá, Universidad de los Andes.

- ÁlVAREZ LONDOÑo, lUIS FERNANDO y GALÁN BARRERA, DIEGO RICARDO (2002): Derecho internacional privado, Bogotá, Pontificia Universidad Javeriana. 
- ANIF-FEDESARROLLO, "El leasing en Colombia: diagnóstico e impacto sobre la inversión y el crecimiento", disponible en: http://www.fedeleasing.org.co/Conceptos/leasing.pdf

- ARChILA PEÑAlosa, EMILIO JOSÉ: Posición de dominio y control de integraciones empresariales, en la Revista Ámbito Jurídico Legis, Bogotá, 28 de abril al 11 de mayo de 2003.

- ARESE, HÉCTOR FÉLIX (1999): "El contrato de leasing", en el libro Comercio y Marketing internacional, Buenos Aires, Grupo Editorial Norma.

- ARRUBLA PAUCAR, JAIME ALBERTO (2008): Contratos mercantiles, T II, Medellín, Editorial Diké.

- ASOCIACIÓN DE BANCOS DEL PERÚ (2014): El leasing como aliado de la actividad productiva, en Asbanc Semanal, N 97, Año 4, viernes 7 de marzo de 2014.

- BANCOLOMBIA (2013): Leasing. Beneficios del arrendamiento operativo.

- BANCOLOMBIA. Leasing. Beneficios tributarios.

- BECK, ULRICH (1998): ¿Qué es la globalización?, Barcelona, Editorial Paidós.

- BERCOVITZ, ALBERTO (1992): La regulación contra la competencia desleal en la ley de 10 de enero de 1991, Cámara de Comercio e Industria de Madrid. 
- BERMAN, HAROLD J (1997): La formación de la tradición jurídica de Occidente, México, Fondo de Cultura Económica.

- BOGGIANO, ANTONIO (1995): Contratos internacionales, Buenos Aires, Ediciones Depalma.

- BONIVENTO FERNÁNDEZ, JOSÉ ALEJANDRO (2000): Los principales contratos civiles y comerciales, T. II, Bogotá, Ediciones Librería del Profesional.

- BOtero RESTREPO, CECILIA (2002): El derecho antitrust o de la libre competencia en los Estados Unidos, Medellín, Señal Editora.

- BROSETA PONT, MANUEL (1991): Manual de derecho mercantil, Madrid, Editorial Tecnos.

- buRgos bONILLA, JOSÉ ALEJANDRO y CABEZAS BARRANTES, CAROLINA (2012): El contrato de leasing, Facultad de Derecho, Universidad de Costa Rica.

- CADAVID GAVIRIA, LEÓN DARíO (2000): Derecho civil. Obligaciones, Bogotá, MacGraw-Hill.

- CALVI, NICOLÁS MARCELO: Análisis del contrato de leasing, Universidad Nacional de Córdoba, Argentina.

- CÁRDENAS QUIRÓS, CARLOS: El leasing o arrendamiento financiero, publicado en la Revista Peruana de Derecho de la Empresa, Contratación, Tomo IV, $\mathrm{N}^{\circ} 39$. 
- CASTILLO TRIANA, RAFAEL (1994): Leasing: mecanismos financiero del futuro, Bogotá, Editorial Hojas e Ideas.

- Código Civil, Bogotá, Editorial Leyer, 2014.

- Código de Comercio, Bogotá, Editorial Leyer, 2014.

- COHNEN, SEBASTIÁN: El contrato de leasing: aspectos de su calificación jurídica, disponible en la Revista Jurídica de la Universidad Autónoma de Madrid, Año 2000, núm. 3, pp. 109-135.

- COLPATRIA. MULTIBANCA. Modelo de contrato de leasing.

- Constitución Política de 1991, Bogotá, Editorial Leyer, 2014.

- COPPARONI, GUIDO LEONARDO (2008): Contrato de leasing: desarrollo de aspectos generales, Mendoza (Argentina), Facultad de Ciencias Económicas y Jurídicas Universidad del Aconcagua.

- Corte Constitucional. Sentencia C-936 de 2003. Expediente 4468. Magistrado Ponente: Eduardo Montealegre Lynnet.

- Corte Suprema de Justicia, Sala Civil. Sentencia de 22 de abril de 2002. Expediente № 6163. Magistrado Ponente: Jorge Antonio Castillo Rugeles.

- Corte Suprema de Justicia, Sala Civil. Sentencia de 13 de diciembre de 2002. Expediente 6462. Magistrado Ponente: Carlos Ignacio Jaramillo. 
- Corte Suprema de Justicia, Sala Civil. Sentencia de 22 de octubre de 2001. Expediente 5817. Magistrado Ponente: Jorge Antonio Castillo Rugeles.

- Corte Suprema de Justicia, Sala Civil. Expediente 2002-00373-01. Magistrado Ponente: William Namén Vargas.

- Corte Suprema de Justicia, Sala Civil. Expediente 11001-3103-038-200100187-01. Magistrado Ponente: Edgardo Villamil Portilla.

- CORREA ARANGO, GABRIEL (2013): Comentarios al estatuto de arbitraje y amigable composición, Bogotá, Editorial Temis.

- CUETO ESTRADA, JUAN PABLO (2009): Reflexiones jurídicas del contrato de leasing, en la Revista Advocatus, Edición especial N 13: 109 -122, 2009, Universidad Libre seccional Barranquilla.

- DALLA VIA, RICARDO (1999): Derecho económico constitucional, Buenos Aires, Editorial Abeledo-Perrot.

- DE SOLÁ CAÑIZARES, FELIPE (1963): Derecho comercial comparado, Barcelona, Editorial Montaner y Simon.

- Decreto 913 de 1993.

- DEPARTAMENTO DE ENTIDADES FINANCIERAS (2007): El leasing financiero: un mercado aun no explotado en Paraguay, diciembre de 2007.

- DURÁN BOHÓRQUEZ, EDWIN GIOVANNI (2004): El contrato de leasing financiero en Colombia, Bogotá, Pontificia Universidad Javeriana. 
- Estatuto Orgánico del Sistema Financiero, Bogotá, Editorial Leyer, 2014.

- ETCHEVERRY, RAÚl ANÍBAL (1995): Derecho comercial y económico, Contratos, parte especial, tomo I, Buenos Aires, Editorial Astrea.

- FARINA, JUAN MANUEL (1999): Contratos comerciales, Buenos Aires, Editorial Astrea.

- FEDELEASING (2010): Manual jurídico del leasing, Bogotá.

- FELDSTEIN DE CÁRDENAS, SARA (1995): Contratos internacionales, Buenos Aires, Editorial Abeledo-Perrot.

- FLORES DOÑA, MARÍA DE LA SIERRA: El leasing financiero internacional en el tratado de UNIDROIT.

- FLORES, SOLEDAD (2012): El leasing inmobiliario, en la Revista Científica de Ciencias Jurídicas y Notariales, Año 2, Vol. 2, pp. 155-170. La Rioja, Argentina.

- GACETA JURÍDICA. Modelo de contrato de leasing.

- GALGANO, FRANCESCO (1992): Negocio jurídico, Valencia, Editorial Tirant lo Blanch.

- GARCía VEGA, ÓsCAR (2007): El leasing, en Autores Varios, Derecho comercial y societario, Bogotá, Ediciones Librería del Profesional.

- GHERSI, CARLOS ALBERTO (2006): Contratos comerciales, T. 2, Buenos Aires, Editorial Astrea. 
- GIL ECHEVERRY, JORGE HERNÁN (2013): Régimen arbitral colombiano. Ley 1563 de 2012, Bogotá, Grupo Editorial Ibáñez.

- GuAl ACOSTA, JOSÉ MANUEL (2012): Cláusulas de exoneración y limitación de responsabilidad civil, Bogotá, Grupo Editorial Ibáñez.

- GUTIÉRREZ APAZA, VERÓNICA ROSSY (2013): Leasing: un buen instrumento de desarrollo para las medianas y pequeñas empresas, Bolivia, Universidad Mayor de San Andrés.

- GUTIÉRREZ HERRERA, ANA LORENA (2003): El contrato de leasing: su desarrollo fiscal en Costa Rica, Universidad Latinoamericana de Ciencia y Tecnología ULACIT.

- HALPERIN, ISAAC (2009): Derecho civil unificado, Buenos Aires, Editorial Astrea.

- HERRERA, MERCADO, HERNANDO (2014): La impugnación de los laudos arbitrales. Análisis legal y jurisprudencial, Bogotá, Legis Ediciones.

- H. LEÓN TOVAR, SOYLA (1999): El arrendamiento financiero (Leasing) en el derecho mexicano. Una opción para el desarrollo, México, Universidad Nacional Autónoma de México.

- JINESTA LOBO, ERNESTO (1992): El contrato de leasing financiero (arrendamiento financiero) con opción de compra, en la Revista Judicial de Costa Rica, Año XVII, № 55, marzo 1992. 
- LEASING TOTAL. Modelo de contrato de leasing o arrendamiento financiero.

- Leguizamón ACOStA, WILliAM (2000): Derecho constitucional económico, Bogotá, Ediciones Jurídicas Gustavo Ibáñez.

- LEYVA SAAVEDRA, JOSÉ (2003): El leasing y su configuración jurídica, en la Revista Vniversitas de la Pontificia Universidad Javeriana, núm. 106, diciembre, 2003, pp. 743-789.

- LÓPEZ GUZMÁN, FABIÁN (2007): Introducción al derecho mercantil, Bogotá, Editorial Temis.

- LÓPEZ GUZMÁN, FABIÁN (2004): Preguntas y respuestas de derecho comercial general, Bogotá, Ediciones Doctrina y Ley.

- maRtínez CAMARgo, ginNA ALEJANDRA y DE LEÓN NOVOA MARTHA ALIDA (2013): Contrato de leasing y cláusulas abusivas. Estudio de su interrelación en el derecho colombiano, Bogotá, Universidad Militar Nueva Granada.

- MARTÍNEZ CAÑELLAS, ANSELMO (2008): Aproximación al contrato de renting, en la Revista Electrónica de la Universidad de Granada, octubre 30 de 2008.

- MARTÍNEZ SÁNCHEZ, WILSON ALEJANDRO: El nuevo Código de Extinción de Dominio, en la Revista Ámbito Jurídico Legis, 2014, p. 3.

- MAVILA, DANIEL (2003): Leasing financiero, en la Revista Industrial Data, vol. (6) 1. 
- Ministerio de Industria, Turismo y Comercio de España - Unión Europea Fondo Social Europeo (2014): Otras técnicas de financiación del comercio internacional. Leasing.

- MORALES ALZATE, JOHN JAIRO (2012): Derecho económico constitucional, Bogotá, Ediciones Doctrina y Ley.

- MORALES CHAVARRÍA, SERGIO (2013): Leasing o arrendamiento financiero, disponible en: http://www.elfinancierocr.com/Centro-FinancieroLeasing-arrendamiento ELFFIL20130918 0002.pdf

- MORENO BASTIDAS, RICARDO (2011): Evolución histórica y jurisprudencial. Alcance del contrato de leasing en Colombia, Universidad San Buenaventura de Cali.

- NORTHCOTE SANDOVAL, CRISTHIAN (2010): Análisis sobre el contrato de leasing o arrendamiento financiero, en Actualidad Empresarial, № 199, segunda quincena de Enero, 2010.

- OLARTE YEPES, CAROLINA (2005): El leasing habitacional: una opción al crédito hipotecario, Medellín, Universidad de Medellín.

- ORTEGA NIÑO, ALEXANDRA MILENA y RUSO, JOHN (2011): La incursión del contrato de renting en Colombia y su desarrollo en ausencia de normativa propia, Bucaramanga, Universidad Industrial de Santander.

- ORTUZAR SOlAR, ANTONIO (1990): El contrato de leasing, Chile, Editorial Jurídica de Chile.

- OSPINA FERNÁNDEZ, GUILLERMO (2008): Régimen de obligaciones, Bogotá, Editorial Temis. 
- PARRA RODRÍGUEZ, EDWIN JOHANN y QUINTANILLA ORTIZ, DIEGO ALEXANDER (2008): Efectos del tratamiento contable del leasing en la estructura financiera de las Pymes: tratamiento contable nacional e internacional, Facultad de Contaduría, Universidad Nacional de Colombia.

- PAZ RUSSI, CARLOS ALBERTO (2012): Análisis al proceso arbitral. Ley 1563 de 2012 y decreto 1818 de 1998, Cali, Universidad San Buenaventura de Cali.

- PEÑA NOSSA, LISANDRO (2014): Contratos mercantiles, Bogotá, Ediciones Ecoe.

- PINZÓN SANTOS, ANGELA MARÍA: Contrato de leasing y medidas cautelares en el proceso ejecutivo en Colombia, Bogotá, Universidad Libre.

- POSNER, RICHARD A (2000): Análisis económico del derecho, México, Fondo de Cultura Económica.

- RAVASSA MORENO, GeRARDO JOSÉ (2000): Antecedentes del leasing en Colombia. Ponencia presentada para la Universidad Santo Tomás en el seminario sobre Derecho de los Negocios.

- RAVASSA MORENO, GERARDO JOSÉ (2001): Derecho comercial. Bienes mercantiles, T. I, Bogotá, Ediciones Jurídicas Gustavo Ibáñez.

- RAVAssa moreno, GERARDO JOSÉ (2004): Derecho mercantil internacional, Bogotá, Ediciones Doctrina y Ley.

- RAVASSA MORENO, GERARDO JOSÉ (1990): Historia del comercio y del derecho mercantil, Bogotá, Universidad Santo Tomás. 
- REVERTE NAVARRO, ANTONIO (1968): El contrato de leasing, Universidad de Murcia.

- RODRÍGUEZ AZUERO, SERGIO (2013): Contratos bancarios. Su significación en América Latina, Bogotá, Editorial Legis.

- ROSENBROCK LAMBOIS, JAVIER: Contrato de leasing, en Errelus, Compendio Jurídico, Tomo 62, p. 47, mayo de 2012.

- RUIZ JIMÉNEZ, KENDALL DAVID (2010): Leasing operativo y leasing financiero, Universidad Escuela Libre de Derecho.

- SAlAZAR, NATALIA; CABRERA, PILAR y BECERRA, ALEJANDRO (2011): El impacto del leasing financiero sobre la inversión y el empleo en las firmas colombianas.

- SANTOS BELANDRO, RUBÉN (2000): Arbitraje comercial internacional, México, Oxford UniversityPress.

- SELMAN NAHUM, ARTURO (2011): La cláusula penal en el contrato de leasing y su nulidad por falta de causa: una evolución en la jurisprudencia, en la Revista Chilena de Derecho, vol. 38, núm. 3, 2011, pp. 611-622. Pontificia Universidad Católica de Chile.

- SOTO, MOISÉS: Leasing. Publicado en monografías.com. Disponible en: http://www.monografias.com/trabajos12/eleasing/eleasing.shtml

- STIGLITZ, JOSEPH (2007): El malestar en la globalización, Barcelona, Editorial Taurus. 
- tamayo lOMBANA, ALBERTO (1990): Obligaciones, Bogotá, Editorial Temis.

- VALENCIA ZEA, ARTURO (1990): Derecho civil obligaciones, Bogotá, Editorial Temis.

- VALLEJO MEJÍA, JESÚS (1992): Obligaciones, Medellín, Editorial Diké.

- VERA MERINO, MARCELO: El contrato de leasing inmobiliario como instrumento de financiamiento para la empresa, disponible en: http://veramerino.com.ar/descargas/Publicacion6.pdf

- VERGARA, JULIO (2014): Leasing. Disponible en: http://api.ning.com/files/05pDTRvDyR8FXHZPzcySXe28ppFvf2QSH25FG8 nQZ5Uon-

T9OrUYviinoBIOILpLoKRFPmVmkW5sBzeCMNI2aSlaNn656E5j/Leasing.pd $\underline{f}$

- VICENT CHULIA, FRANCISCO (2001): Introducción al derecho mercantil, Valencia, Editorial Tirant lo Blanch.

- YANG POJAN (2002): Contrato de leasing, Departamento de Investigación, Universidad de Belgrano. 
